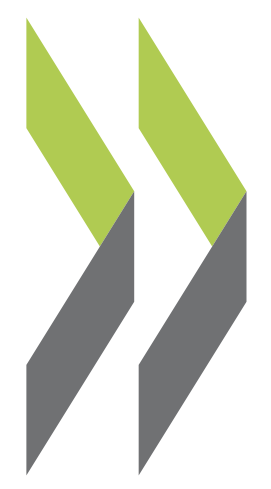

OECD Environment Working Papers No. 30

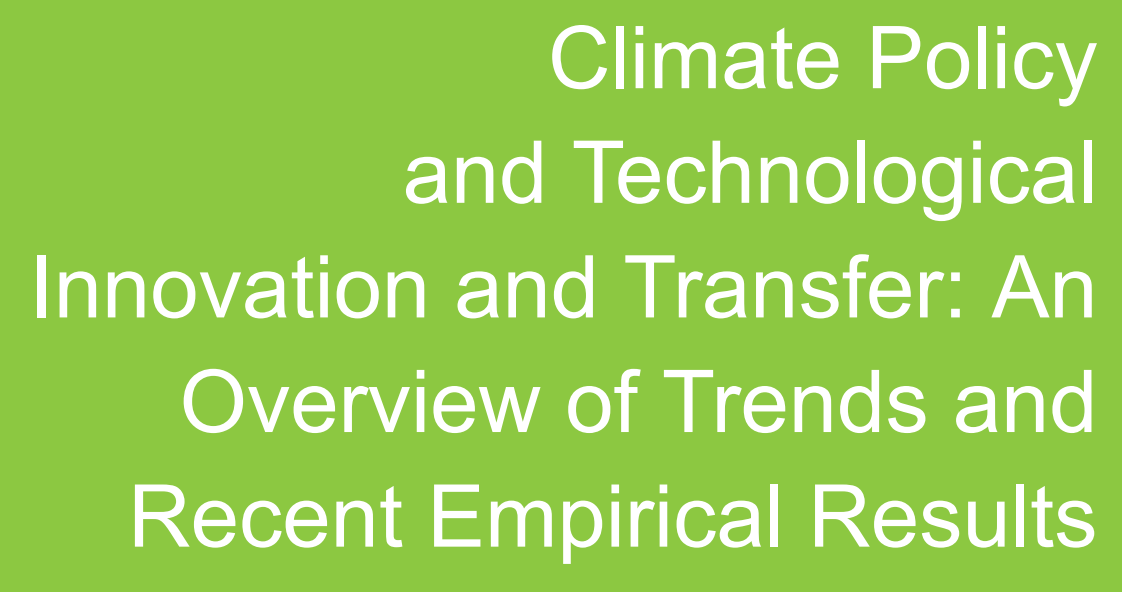

Ivan Haščič,

Nick Johnstone,

Fleur Watson,

Christopher Kaminker 
Organisation de Coopération et de Développement Économiques

Organisation for Economic Co-operation and Development

\section{ENVIRONMENT DIRECTORATE}

ENVIRONMENT WORKING PAPER NO. 30

CLIMATE POLICY AND TECHNOLOGICAL INNOVATION AND TRANSFER: AN OVERVIEW OF TRENDS AND RECENT EMPIRICAL RESULTS

by Ivan Haščič, Nick Johnstone, Fleur Watson and Chris Kaminker

JEL Classification: Q42, Q54, Q55, Q58, O31, O33

Keywords: Environmental Policy, Climate Change, Innovation, Technology Transfer

All Environment Working Papers are available at www.oecd.org/env/workingpapers 


\section{OECD ENVIRONMENT WORKING PAPERS}

This series is designed to make available to a wider readership selected studies on environmental issues prepared for use within the OECD. Authorship is usually collective, but principal authors are named.

The papers are generally available only in their original language English or French with a summary in the other if available.

The opinions expressed in these papers are the sole responsibility of the author(s) and do not necessarily reflect those of the OECD or the governments of its member countries.

Comment on the series is welcome, and should be sent to either env.contact@oecd.org or the Environment Directorate, 2, rue André Pascal, 75775 PARIS CEDEX 16, France.

OECD Environment Working Papers are published on www.oecd.org/env/workingpapers

Applications for permission to reproduce or translate all or part of this material should be made to: OECD Publishing, rights@oecd.org or by fax 33145249930.

Copyright OECD 2010 


\begin{abstract}
Technological innovation can lower the cost of achieving environmental objectives. As such, understanding the linkages between environmental policy and technological innovation in achieving environmental objectives is important. This is particularly true in the area of climate change, where the economic costs of slowing the rate of change are affected to a great extent by the rate of innovation. This paper provides evidence on the generation and international diffusion of selected climate change mitigation technologies (CCMTs) and their respective links to key policies. The data covers a selection of technology fields (renewable energy and 'clean' coal) and all countries over the last 30-35 years.
\end{abstract}

JEL Classification: Q42, Q54, Q55, Q58, O31, O33

Keywords: Environmental Policy, Climate Change, Innovation, Technology Transfer

\title{
RÉSUMÉ
}

L'innovation technologique peut abaisser le coût de la réalisation des objectifs environnementaux. A ce titre, il importe de comprendre les liens entre politique de l'environnement et innovation technologique dans la mise en œuvre des objectifs, notamment dans le domaine du changement climatique, où le taux d'innovation a une forte incidence sur les coûts économiques du ralentissement du phénomène. Le présent ouvrage fournit des données sur la création et la diffusion internationale de certaines technologies d'atténuation du changement climatique, et sur leurs liens avec les principales initiatives des pouvoirs publics. Les données portent sur un éventail de domaines technologiques (énergies renouvelables et charbon propre) et, pour tous les pays, sur les 30 à 35 dernières années.

Codes JEL : Q42, Q54, Q55, Q58, O31, O33

Mots clés : politique environnementale, changement climatique, innovation, transfert de technologie, innovation 


\section{FOREWORD}

The OECD Environment Directorate has been examining the relationship between environmental policy design and technological innovation since 2005 (www.oecd.org/environment/innovation). This paper is a contribution to this work programme, focussing on the area of climate change mitigation. Patent data is used to assess the role of policy (and other) factors on the development and international transfer of a wide variety of mitigation technologies.

The report has been prepared by Ivan Haščič, Nick Johnstone, Fleur Watson and Chris Kaminker (all of the OECD Secretariat). The search strategies which have been used to identify relevant patent documents have been developed by a team of patent examiners at the European Patent Office, led by Victor Veefkind. Technical inputs from Hélène Dernis (OECD Directorate for Science, Technology and Industry) and Dominique Guellec (OECD Statistics Directorate) are also gratefully acknowledged. And finally, the report has benefited from comments received by delegates to the OECD's Working Party on National Environmental Policies and Working Party on Global and Structural Policies. 


\title{
TABLE OF CONTENTS
}

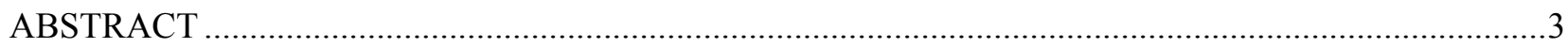

RÉSUMÉ

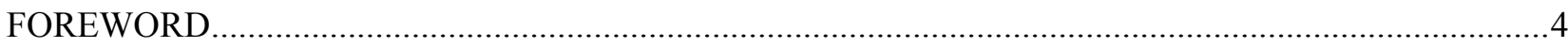

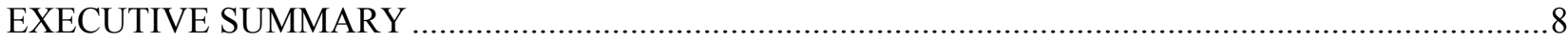

CLIMATE POLICY AND TECHNOLOGY INNOVATION AND TRANSFER: AN OVERVIEW OF TRENDS AND RECENT EMPIRICAL RESULTS..............................................................................
\end{abstract}

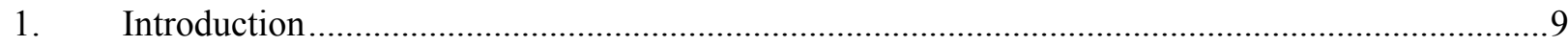

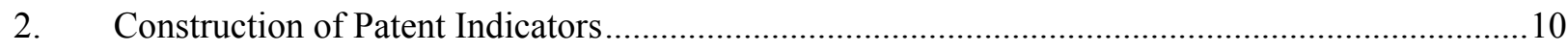

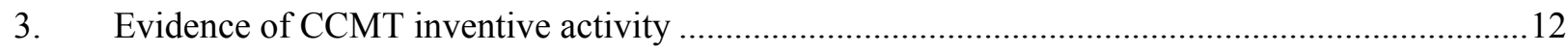

4. Determinants and Consequences of CCMT Innovation: the Role of Policy .................................22

5. Technology Transfer, Knowledge Spillovers and Research Co-operation ....................................31

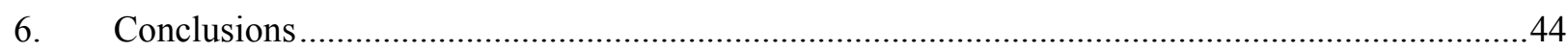

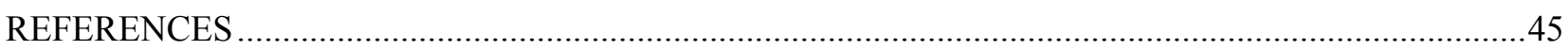

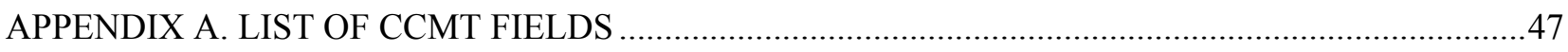

APPENDIX B. COMPARISON OF COUNTS FOR DIFFERENT TYPES OF PATENT CLAIM............49

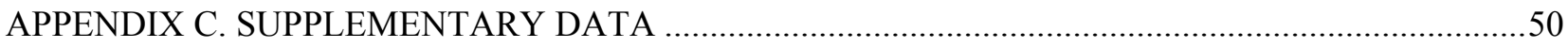

APPENDIX D. SELECTED POLICY MEASURES AND PATENT COUNTS …...................................60

APPENDIX E. USING PATENT DATA AS AN INDICATOR OF INTERNATIONAL TECHNOLOGY

TRANSFER. 


\section{Tables}

Table 1. Selected Climate Change Mitigation Technologies (CCMTs) Covered in this Report........10

Table 2. Rank of top inventor countries 1988-2007 (counting CP), by CCMT class.........................19

Table 3. Specialisation of inventor countries in CCMT fields (1988-2007) ...................................20

Table 4. Major applicants in CCS \& IGCC technologies (1988-2007) ….........................................22

Table 5. Correlation between CCMT patenting and specific R\&D expenditures ............................27

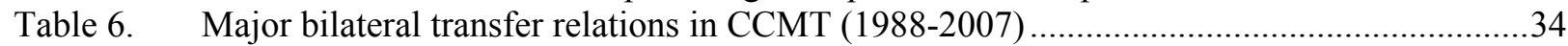

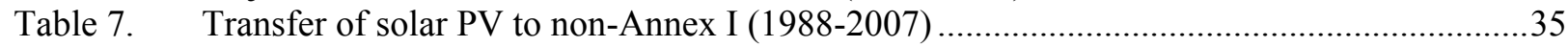

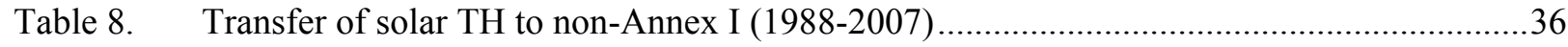

Table 9. International Research Collaboration in CCMT (co-invention) ...........................................39

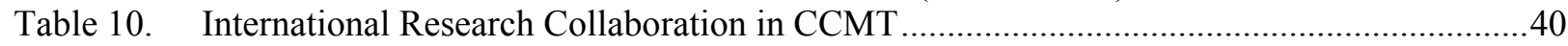

Table 11. Patenting activity of inventor countries in selected CCMT fields (1988-2007) ...................50

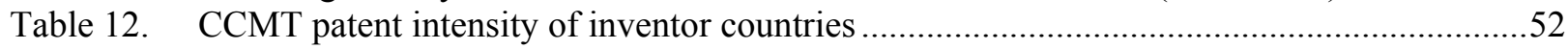

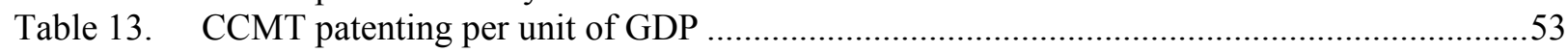

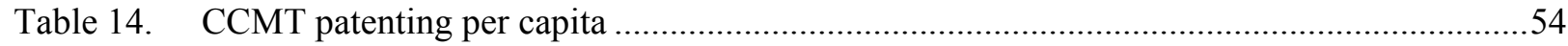

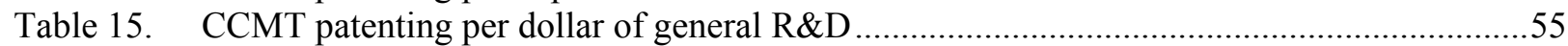

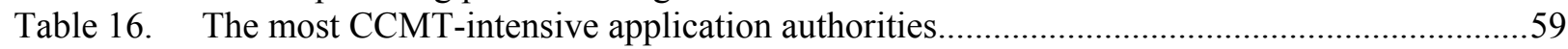

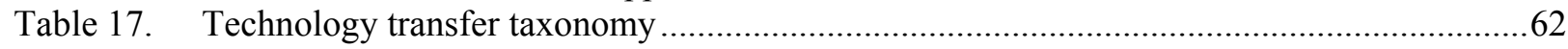

Table 18. Correlations between trade values and counts of duplicate patent applications ...................63

\section{Figures}

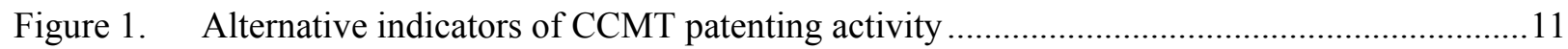

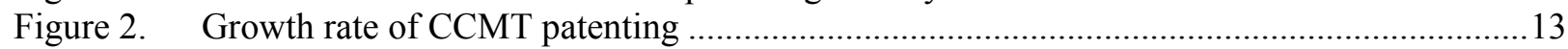

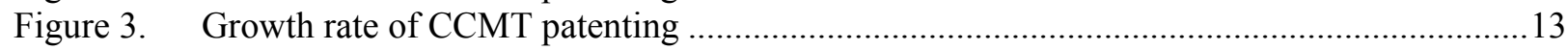

Figure 4. Inventive activity in solar thermal versus solar PV ........................................................ 14

Figure 5. Inventive activity in geothermal technologies (1970-2007) ..........................................15

Figure 6. Inventive activity in hydro/marine technologies (1950-2007) .........................................15

Figure 7. Inventive activity in biofuels technologies (1970-2007) .................................................. 16

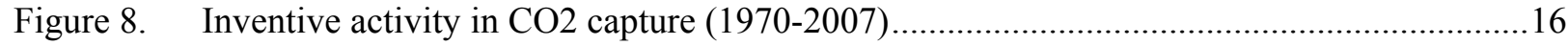

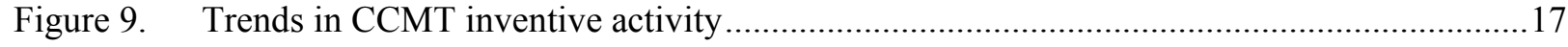

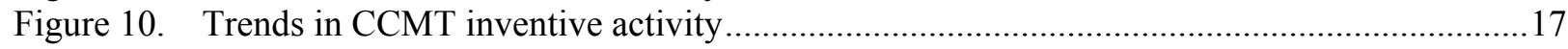

Figure 11. Inventor countries for solar thermal and solar PV ......................................................18

Figure 12. Proportion of patenting (CP) by the top 5 ranking inventor countries for each CCMT

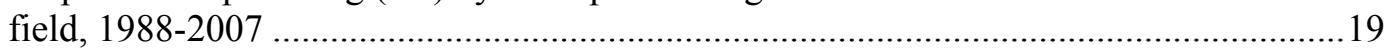

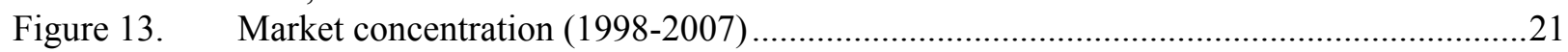

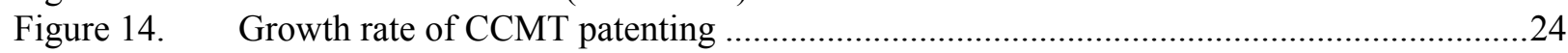

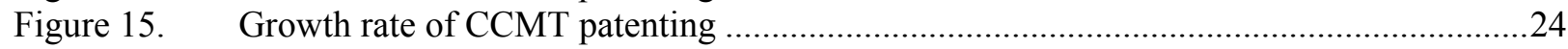

Figure 16. Crude oil prices (2006 USD) and biofuels patenting (CP) ..........................................25

Figure 17. Patenting Activity and Government Expenditures on Energy Technology R\&D

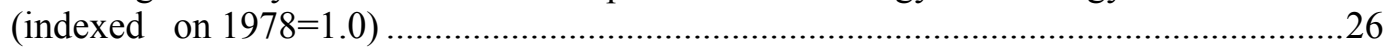

Figure 18. Introduction of renewable energy policies by type in OECD countries ..........................28

Figure 19. Effect of Different Factors on Renewable Energy Patents (CPs) ...................................29

Figure 20. Effect of Renewable Energy Certificates on Renewable Energy Patents (CPs)................30

Figure 21. Effect of Feed-in Tariffs on Renewable Energy Patents (CPs) ........................................30

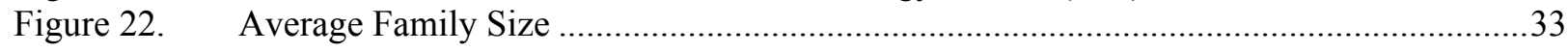

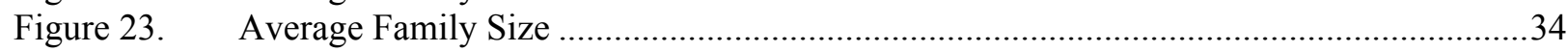

Figure 24. International Transfer of Selected CCMT Technologies, from Annex I to non-Annex I

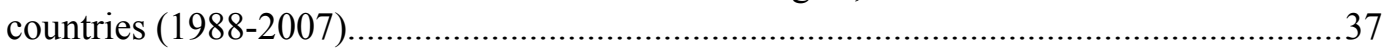

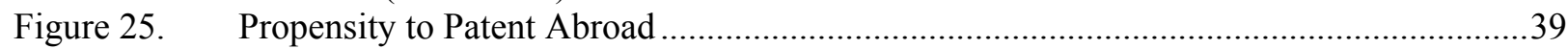

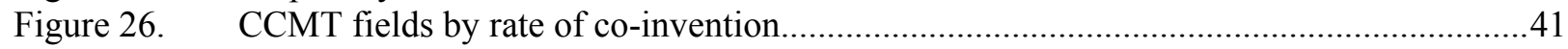


Figure 27. International Research Collaboration in Selected CCMT Technologies (1988-2007).....42

Figure 28. The Relative Importance of Different Patent Claims ...................................................49

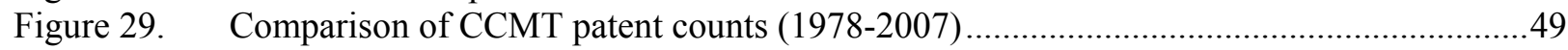

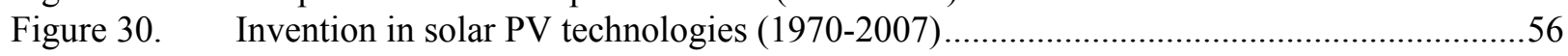

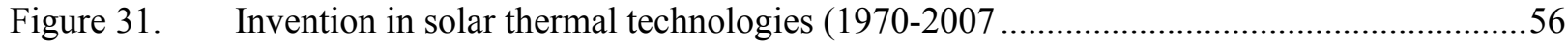

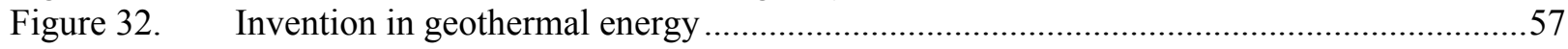

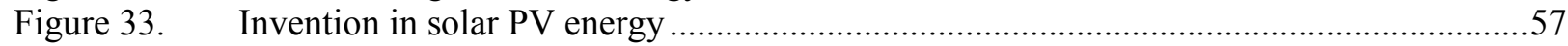

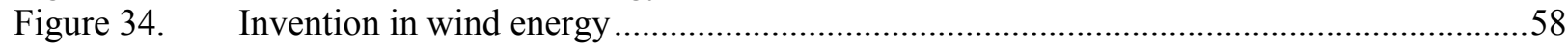

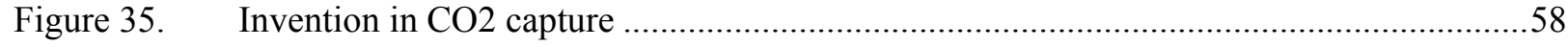

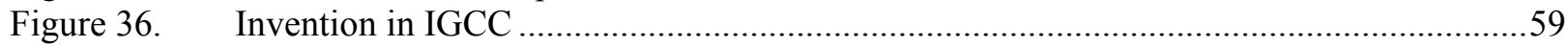

Figure 37. Targets for renewable energy certificates (REC \%) and CCMT patenting (CP).............60

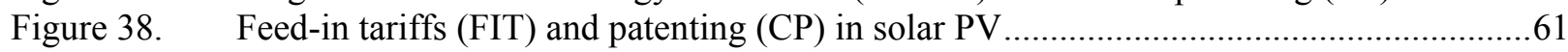

Figure 39. Feed-in tariffs (FIT) and patenting (CP) in wind power...............................................61

Figure 40. Aggregate patent transfer counts and aggregate exports for road vehicles 1988-2005....64 


\section{EXECUTIVE SUMMARY}

This paper provides evidence on the generation and diffusion of selected climate change mitigation technologies (CCMTs) and their respective links to key policies. Based upon search strategies developed by a team of patent examiners at the European Patent Office, harmonised patent counts have been extracted from the EPO/OECD World Patent Statistics (PATSTAT) database. The data covers a selection of technology fields (renewable energy and 'clean' coal) and all countries over the last 30-35 years.

Based on the data presented, it is interesting to note that the rate of innovation has accelerated in many CCMTs, coinciding approximately with the passage of the Kyoto Protocol. This is particularly true of those technologies that were closest to being competitive - i.e. wind power, some solar power, biofuels, geothermal and hydro. Patent activity for other technologies (i.e. CCS) showed falls, even in comparison with the rate of patenting in general and for other energy technologies.

The data reveals that different countries specialise in different areas of CCMT innovation. For instance, Japan and Korea are particularly prominent in solar PV technologies, Denmark in wind power technologies, and Norway in hydro/marine technologies. However, a number of 'emerging' economies are becoming increasingly active - e.g. China, India and South Africa.

Empirical analysis indicates that the most important determinant of innovation in the area of renewable energy technologies is general innovative capacity. A country with a high rate of innovation in general, will be innovative with respect to CCMTs. However, public policy makes a difference. Public $R \& D$ expenditures on renewable energies induce innovation, as do targeted measures such as renewable energy certificates and feed-in tariffs.

The effects of different measures vary by type of renewable. This is partly due to policy design, with more competitive sources benefiting from measures which do not differentiate by type of renewable. For this reason the effect of renewable quotas have a greater impact on less costly wind power innovation, while differentiated feed-in tariffs benefit more expensive technologies such as solar photovoltaics. A key policy question is to determine whether the use of differentiated policy instruments is economically efficient.

With respect to technology diffusion and transfer, there is evidence of significant CCMT equipment and knowledge flows across countries. While much of the technology transfer and international research co-operation is amongst Annex 1 countries, there are non-Annex 1 countries that have become significant trade and research partners. This is important since the international diffusion of environmental and CCMTs and knowledge is key to addressing global environmental problems such as climate change.

Empirical evidence presented indicates that the Clean Development Mechanism has played a statistically significant role in encouraging transfer of wind power technologies from Annex 1 to nonAnnex 1 countries. However, domestic innovative (or absorptive) capacity in the recipient countries is considerably more important. In order to benefit from technologies available on the international market, recipient countries need to have innovation capacity themselves. 
ENV/WKP(2010)16

\section{CLIMATE POLICY AND TECHNOLOGY INNOVATION AND TRANSFER: AN OVERVIEW OF TRENDS AND RECENT EMPIRICAL RESULTS}

\section{Introduction}

Technological innovation can lower the cost of achieving environmental objectives. As such, understanding the linkages between environmental policy and technological innovation in achieving environmental objectives is important. This is particularly true in the area of climate change, where the economic costs of slowing the rate of change are affected to a great extent by the rate of innovation. ${ }^{1}$ While the role that public policy can play in accelerating the development and diffusion of climate change mitigation technologies is important, empirical evidence in this area remains is scant.

This report summarises recent work undertaken at the OECD Environment Directorate with respect to innovation in climate change mitigation technologies (CCMTs). The paper presents data on innovation across a wide range of countries over the last three decades. It also presents the results of empirical work undertaken on the determinants and consequences of innovation in this area. Related work on the the international transfer of CCMTs is also presented, as well as evidence on the extent of international research cooperation.

Empirical analysis of the effects of policy on technical innovation requires a quantitative measure of innovation. While there is no ideal measure, patent data have been widely used as a proxy measure to assess the effects of policy and other factors on technological innovation in general. ${ }^{2}$ Given the means by which patent claims are classified, they are particularly useful when analysing innovation in specific technological fields. As such, in this report patent data is used to assess the nature, extent, and causes of innovation in the "environmental" context, with a focus on selected climate change mitigation technologies (CCMTs).

Two recent papers focus on climate change mitigation and use patent data to present on trends in climate change innovation. Lee et al. (2009) present data on six energy technologies using a 'patent landscaping' technique: wind, solar photovoltaic (PV), concentrated solar power (CSP), biomass-toelectricity, carbon capture and cleaner coal. ${ }^{3}$ Dechezlepretre et al. (2009) cover a somewhat wider range of technologies in their paper. They use the EPO/OECD World Patent Statistics Database (PATSTAT) to extract data based on the International Patent Classification (IPC) system. The use of a relational database such as PATSTAT allows for greater commensurability of data across fields, time and countries. ${ }^{4}$

This report combines the approaches in the two aforementioned reports to present and assess new data on patented innovations in the area of climate change mitigation. Specifically, the 'depth' of 'patent

\footnotetext{
${ }^{1}$ See OECD (2009d) The Economics of Climate Change Mitigation (Paris: OECD).

${ }^{2}$ See review of the literature below.

${ }^{3}$ The 'patent landscaping' technique involves a combination of Boolean search algorithms, targeted patent class-based searches and assignee-focused searches of publicly-available data. This allows for comprehensive identification of relevant patents.

${ }^{4}$ For instance, documents which are members of a single patent family can be identified. However, some relevant documents captured through more 'ad hoc' search strategies may be missed.
} 
landscaping' is combined with the 'rigour' of statistical extractions. ${ }^{5}$ In addition, by focussing on 'claimed priorities' (patents for which protection has been sought in at least two countries) only 'high-value' patents are included. Table 1 gives an indication of the fields covered, while the complete hierarchy of the CCMT fields is provided in Appendix A.

Table 1. Selected Climate Change Mitigation Technologies (CCMTs) Covered in this Report

\begin{tabular}{|c|c|}
\hline Source of Energy & Comments \\
\hline Solar & Photovoltaic (PV), Thermal, Hybrid \\
\hline Wind & incl. On- and Offshore \\
\hline $\begin{array}{l}\text { Geothermal } \\
\text { Hydro } \\
\text { conventional }\end{array}$ & \\
\hline Marine (Ocean) & Kinetic, Salinity, Thermal \\
\hline Bio Fuels & incl. Biomass Heat/Power \\
\hline Fossil (Coal) & IGCC, $\mathrm{CO}_{2}$ Capture and Storage \\
\hline
\end{tabular}

The report is structured as follows. Section 2 discusses the construction of the data. Section 3 presents data on the evidence of inventive activity through patent counts, followed by a preliminary assessment of the role of public policy in encouraging such trends in Section 4. Section 5 presents evidence on the transfer of such technologies and the extent of international co-operation in CCMT innovation research. There is a brief concluding section which ties the findings together.

\section{Construction of Patent Indicators}

All measures of innovation are imperfect. For instance, R\&D data is unsatisfactory insofar as it measures an input to innovation, rather than an output. Data on scientific personnel suffers from a similar shortcoming. In recent years, bibliometric data has been used, but it can be difficult to develop efficient search strategies, and the link between publication and value is likely to be imperfect at best (see OECD $2009 \mathrm{~b}$ for a discussion). ${ }^{6}$

As an alternative, patent data have often been used as a measure of technological innovation because they focus on outputs of the inventive process (Griliches 1990, OECD 2009a). Patent data provide a wealth of information on the nature of the invention and the applicant, the data is readily available (if not always in a convenient format), discrete (and thus easily subject to the development of indicators). Significantly, there are very few examples of economically significant inventions which have not been patented (Dernis

\footnotetext{
${ }^{5}$ The merits of the procedure can be summarised as:

- The search strategies have been developed by patent examiners at the European Patent Office who are specialised in the different fields covered;

- The patents have been identified individually in the EPO's EPODOC database, which is the most comprehensive source of data on patent documents;

- In addition to using keywords, the searches are based on the European Classification system (ECLA), which provides a significant advantage over previous searches based on the International Patent Classification (IPC) system or other systems: and,

- The final extractions have been drawn from the EPO/OECD World Patent Statistics database (PATSTAT), which allows for the development of indicators which are commensurable across time and countries, allows for the identification of 'high-value' patents, and which provide a variety of other data (e.g. assignees and inventors).

${ }^{6}$ For a discussion of the relative merits of different measures see OECD (2008) and Johnstone and Haščič (2009).
} 
et al. 2001). Most importantly, the application-based nature of the patent classification systems allows for a richer characterisation of relevant technologies.

This report has been prepared using data extracted from PATSTAT APR09 based on EPO's identification of patent applications that are relevant to CCMTs. There is no ideal way of measuring patenting activity across countries, patent offices, and over time. However, some approaches to such international comparisons are more suitable than others. For example, the concept of a triadic patent family (TPF) has been developed by constraining the interest only to a small subset of high-value patents. However, in the context of the CCMTs the TPF is not a suitable approach because the constraint it imposes is overly restrictive (this would of course hold for other rather narrow technological fields as well). Indeed, the TPF counts for many CCMT fields are very low, limiting the variation in the data and thus rendering any useful international comparisons impossible (see Figure 1). This problem is, of course, even greater for the individual CCMT sub-categories.

Figure 1. Alternative indicators of CCMT patenting activity

(Based on simple counts of EPO filings, CPs worldwide, and triadic counts)

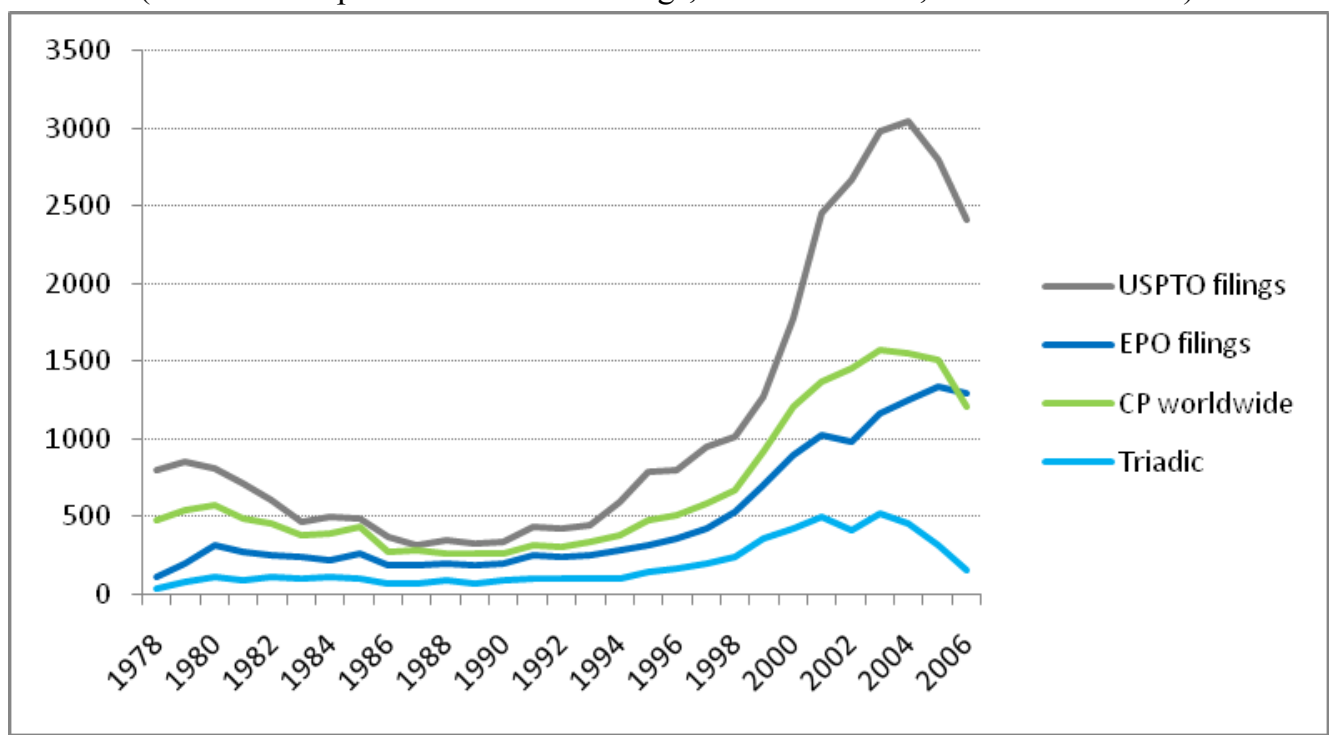

In this report we apply the concept of 'claimed priorities' (i.e. patent applications that have been claimed as priority elsewhere in the world) to measure patenting activity because, other things being equal, these are inventions of higher value. Previous research has shown that the number of additional patent applications (other than the priority application) is a good indicator of patent value (Guellec and van Pottelsberghe 2000; Harhoff et al. 2003). ${ }^{7}$

For the purpose of international comparisons, this statistic may be preferable for several reasons: (i) considering only priority applications (and not their duplicates) avoids double-counting - which would occur if data from multiple patent offices were pooled. The data is thus better suited for cross-country analysis; (ii) considering only 'claimed priorities' provides a quality threshold as priority applications which have never been claimed (singulars) are excluded. This helps contain any concerns over strategic patenting; and finally, (iii) the data are truly world-wide in their coverage, because the entire stock of patent priorities is considered.

\footnotetext{
${ }^{7}$ The results in Guellec \& van Pottelsberghe (2000) suggest that patent value increases up to family size of 4 (or 5), and decreases thereafter. However, few patent applications have family size greater than five.
} 
We identify the relevant patent applications using data on patent families (priorities and equivalents). ${ }^{8}$ We construct frequency counts of claimed priorities (CP) deposited at any office world-wide, classified by technological field (based on identification developed by the EPO), priority date $e^{9}$ (based on the first application filing date world-wide), application authority ${ }^{10}$, and inventor country (country of residence of the inventors ${ }^{11}$, generated as fractional counts ${ }^{12}$ ). CPs account for a relatively small proportion of the stock of CCMT patent applications, with protection for over $60 \%$ of all CCMT inventions only being sought at a single office (SING). However, there is significant variation across offices (See Appendix B.)

\section{Evidence of CCMT inventive activity}

\section{Trends through time}

The rate of increase in CCMT claimed priorities has been remarkably rapid in the last decade sometimes in excess of $20 \%$ per annum (see Figure 2). However, it is well-known that there has been a general increase in inventive activity (and the propensity to patent) across all technology fields. As such in order to gain a better indication of the rate of increase the Figure also shows claimed priorities for patents which relate to patenting in conventional (fossil-fuel and nuclear) energy fields and for patenting overall. ${ }^{13}$ As can be seen, CCMT innovation is far outstripping the rate of increase in patenting in general. Fossil fuel efficiency patents have been stagnant.

\footnotetext{
${ }^{8}$ Using data on patent family, the following types of documents are distinguished: Singular is patent applied for at a single office, with no subsequent filings elsewhere (i.e. patent family size $=1$ ); Claimed priority $(\mathrm{CP})$ is patent for which an application is filed at an additional office to that of the "priority office"; these are inventions that have been applied for protection in multiple countries (patent family size $>1$ ); Finally, duplicate is the additional application.

9 'Priority date' indicates the earliest application date worldwide (within a given patent family).

${ }^{10}$ For a list of application authorities (patent offices) included, and their abbreviations used, see http://documents.epo.org/projects/babylon/eponet.nsf/0/2464E1CD907399E0C12572D50031B5DD/\$File/global_paten t_data_coverage_0708.pdf. See also http://www.wipo.int/standards/en/pdf/03-03-01.pdf

${ }^{11}$ For a list of two-digit abbreviations of country names, developed by the International Organisation for Standardisation, see http://www.iso.org/iso/country_codes.htm; The relevant WIPO document is available at http://www.wipo.int/standards/en/pdf/03-03-01.pdf

${ }^{12}$ Generating the counts as 'fractional' means that if inventors from two (or three, or more) different countries are involved, only a fraction of $0.5(0.33$, etc.) will be counted for a given patent application.

${ }^{13}$ Note that 'TOTAL' refers to the entire stock of corresponding patent applications contained in PATSTAT. It is commonly used as a 'normalisation' factor to account for differences in propensity to patent across countries and over time. This is fully appropriate when the 'environmental' patents are identified using IPC classes, since most patent documents in PATSTAT do have an IPC class attributed. In cases when (English) keywords are used to complement the IPC search strategy, a corresponding 'PATSTAT TOTAL' can be constructed by selecting only applications with (English) abstracts to mitigate the potential language bias. However, the EPO's CCMT search strategy is rather complex, including not only IPC classes and keywords but also symbols from ECLA and other alternative classification systems which are not included in the current edition of PATSTAT. Consequently, we were unable to construct a corresponding 'PATSTAT TOTAL' and would need EPO's help in this regard. Until then, the current approach is not without shortcomings. These include the potential ECLA bias (the population of patent applications attributed an ECLA code is unknown) and language bias (due to searches in selected languages).
} 
Figure 2. Growth rate of CCMT patenting

(Count of CPs worldwide, 3-year moving average, indexed on 1978=1.0)

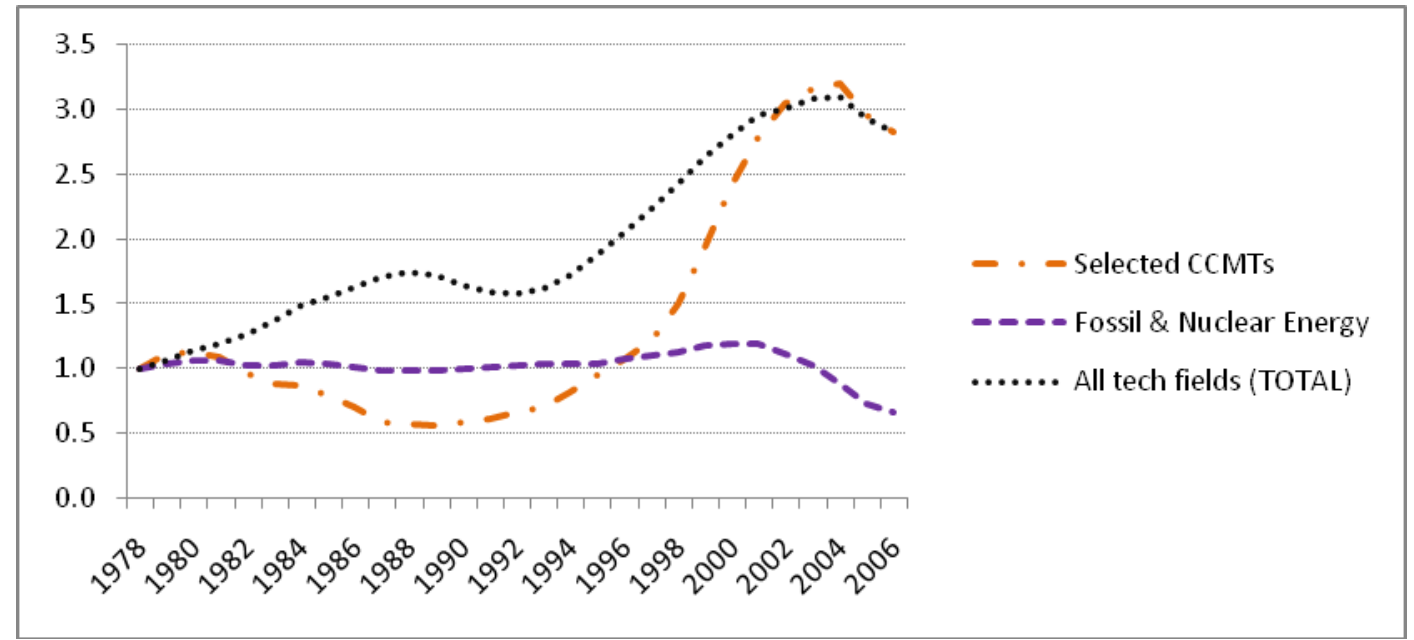

Figure 3 disaggregates the data by the classifications set out in Table 1 above. Wind power, solar photovoltaic (but not thermal) and $\mathrm{CO}_{2}$ capture have been exhibiting particularly rapid growth in recent years. Somewhat surprisingly, Integrated Gasification Combined-Cycle (IGCC) patent activity is growing more slowly than the rate of patenting in general. However, this is probably attributable to the general stagnancy of fossil fuel patenting in general.

Figure 3. Growth rate of CCMT patenting

(Count of CPs worldwide, 3-year moving average, indexed on 1978=1.0)

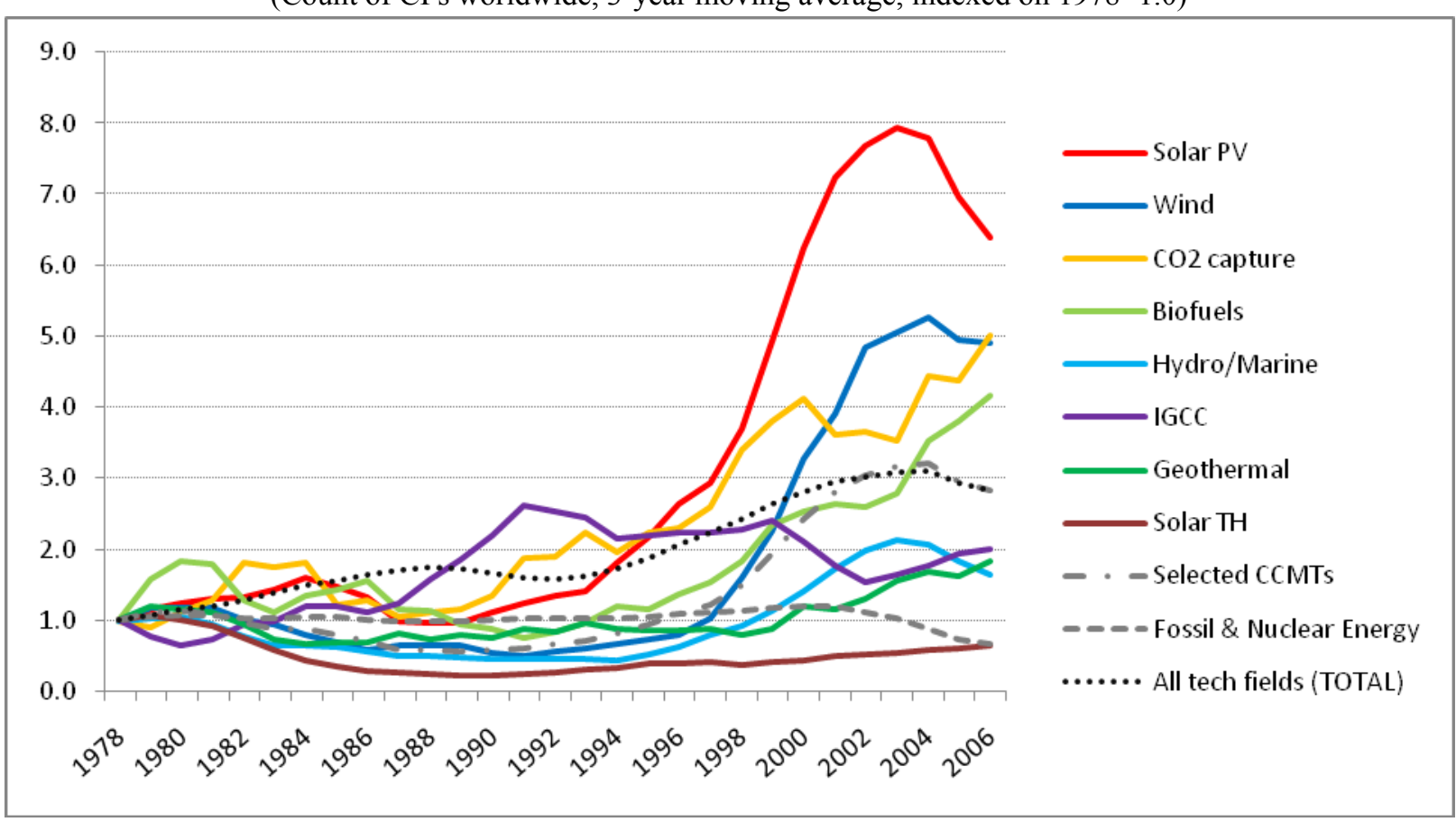

The aggregate data presented thus far gives a good indication of trends in the invention of CCMT technologies. However, within individual fields there can be significant variation, with different technology types being much more mature than others. This can be seen clearly in Figure 4 below where 
data on solar thermal and solar PV technologies are compared. Solar thermal (a much more mature technology) reached its peak in the late 1970s, while solar PV is still growing.

Figure 4. Inventive activity in solar thermal versus solar PV

(CPs worldwide, 3-year moving average)

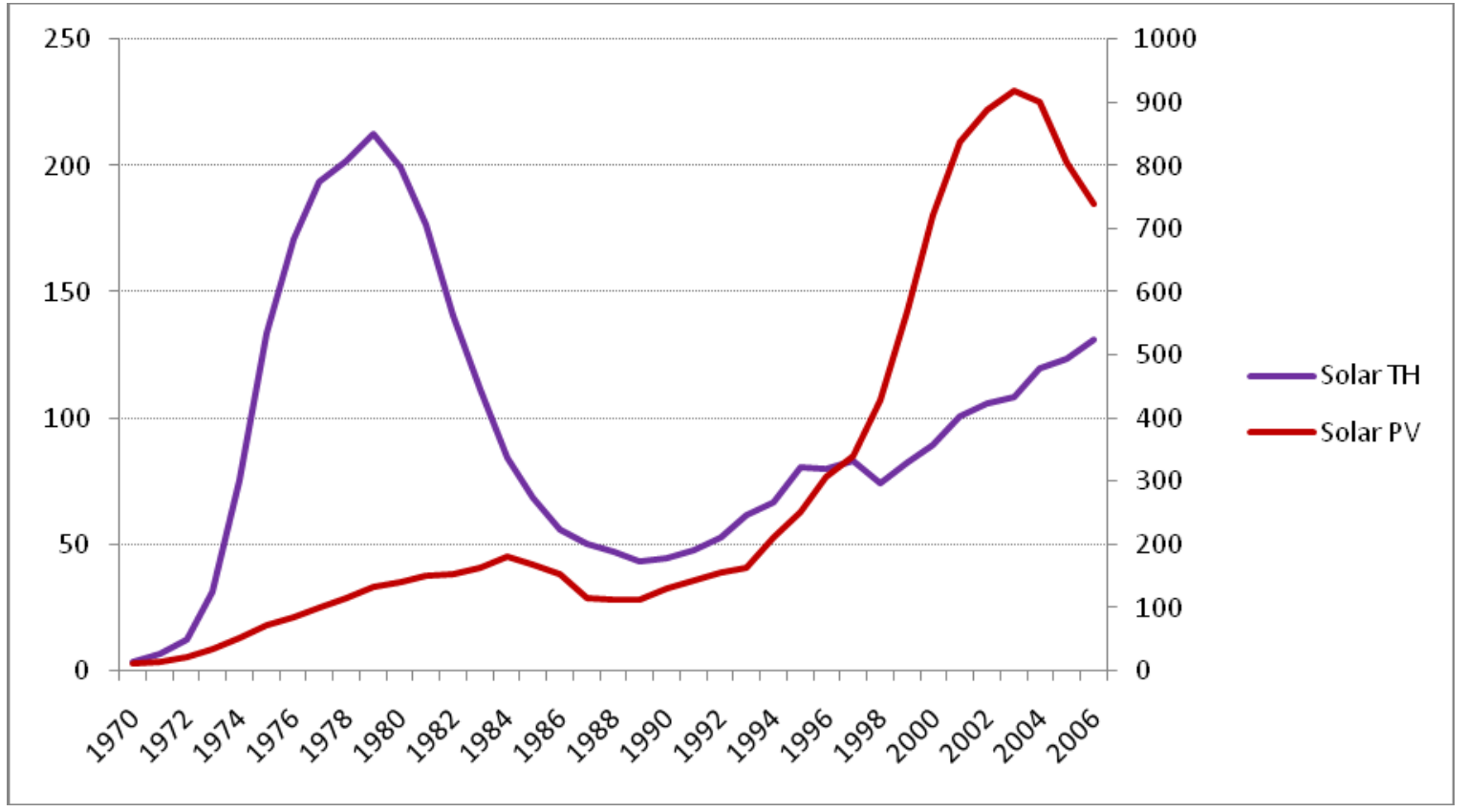

In the case of solar thermal technologies (see Appendix C) the most evident trend is the fall in the proportion of patents which relate to heat exchange systems, with mechanical technologies (mounting and tracking) showing growth. Conversely, in the case of geothermal technologies, hydro/marine, biofuels, and $\mathrm{CO}_{2}$ capture technologies there are clear trends:

- In the case of geothermal it is material technologies related to pipes which have grown, while drilling technologies have fallen;

- In hydro, conventional hydro technologies have become less important, while stream and wave technologies have grown;

- In biofuels it is diesel technology patenting which has grown most quickly; and,

- In $\mathrm{CO}_{2}$ capture, absorption and condensation have fallen, while absorption technologies and chemical capture have risen. 
Figure 5. Inventive activity in geothermal technologies (1970-2007)

(\% share of Geo_all, 3-year moving average)

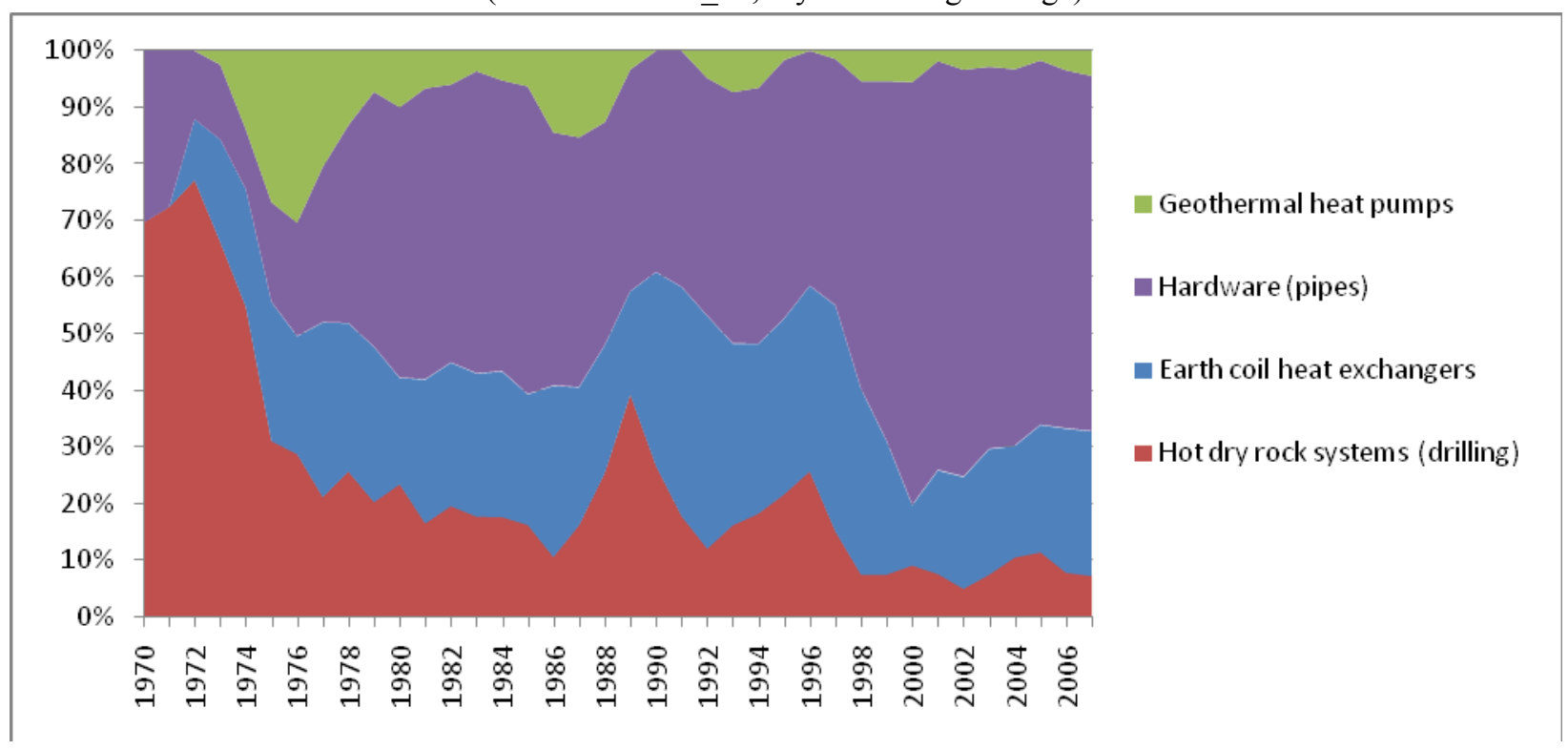

Figure 6. Inventive activity in hydro/marine technologies (1950-2007) (\% share of Hydro_all, 3-year moving average)

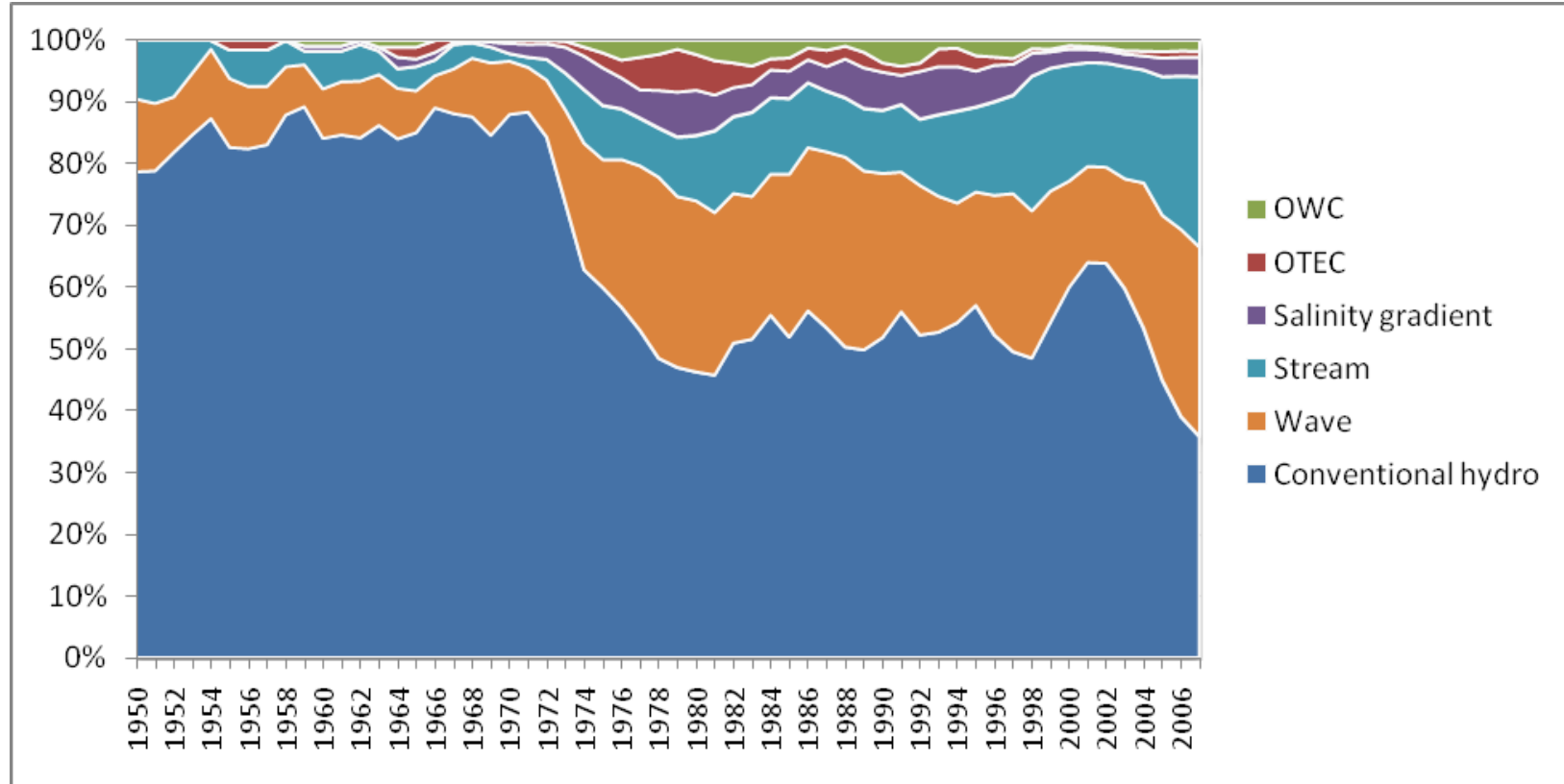

Note: OTEC = Ocean thermal energy conversion; OWC = Oscillating water column; "Stream" is mainly "river and tidal". 
Figure 7. Inventive activity in biofuels technologies (1970-2007)

(\% share of biofuels_all, 3-year moving average)

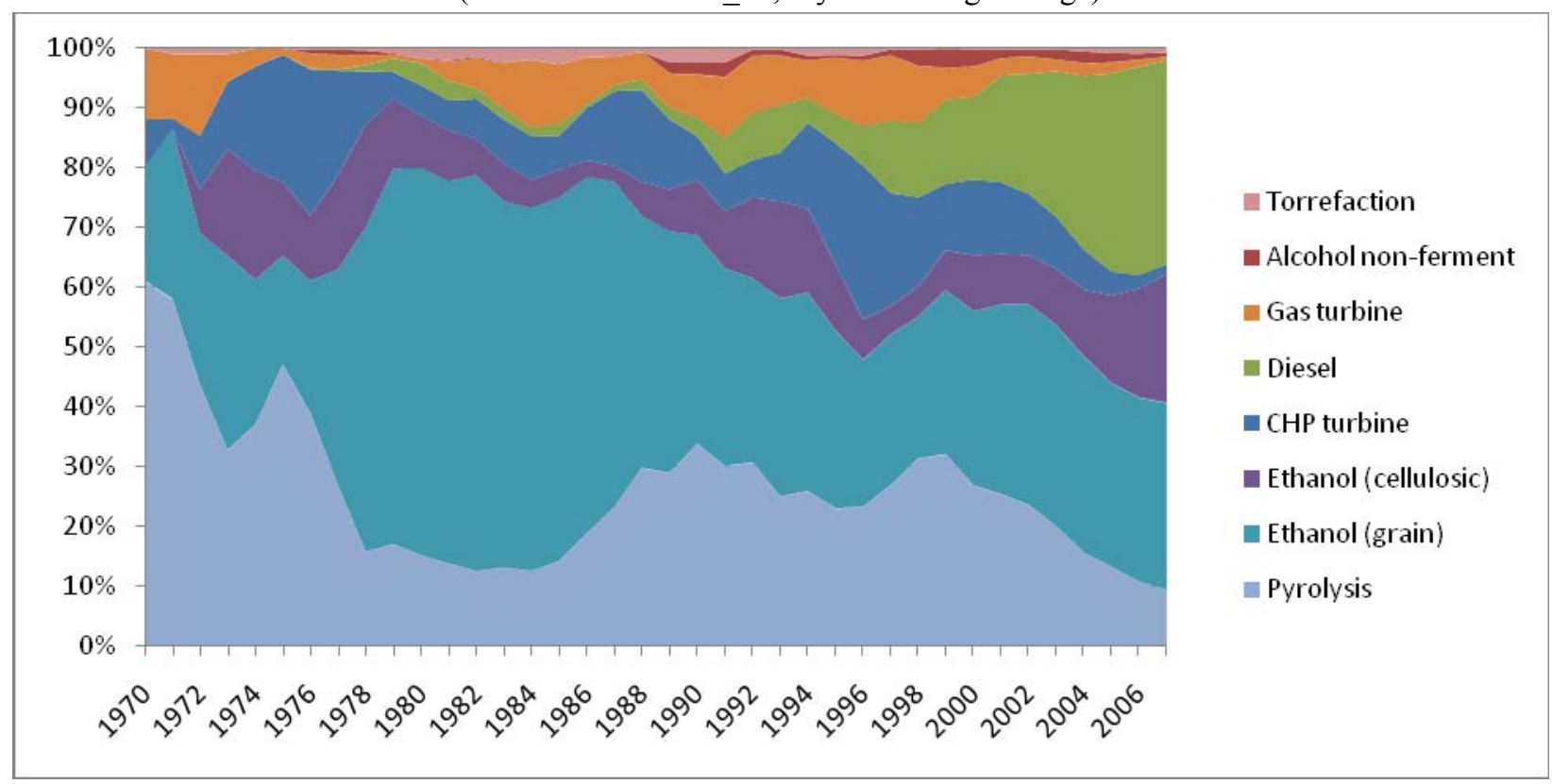

Note: CHP turbines = combined heat and power plant turbines for bio-feed; Gas turbines = gas turbines for bio-feed; Alcohol nonferment $=$ bio-alcohols produced by other means than fermentation.

Figure 8. Inventive activity in $\mathrm{CO} 2$ capture (1970-2007)

(\% share, 3-year moving average)

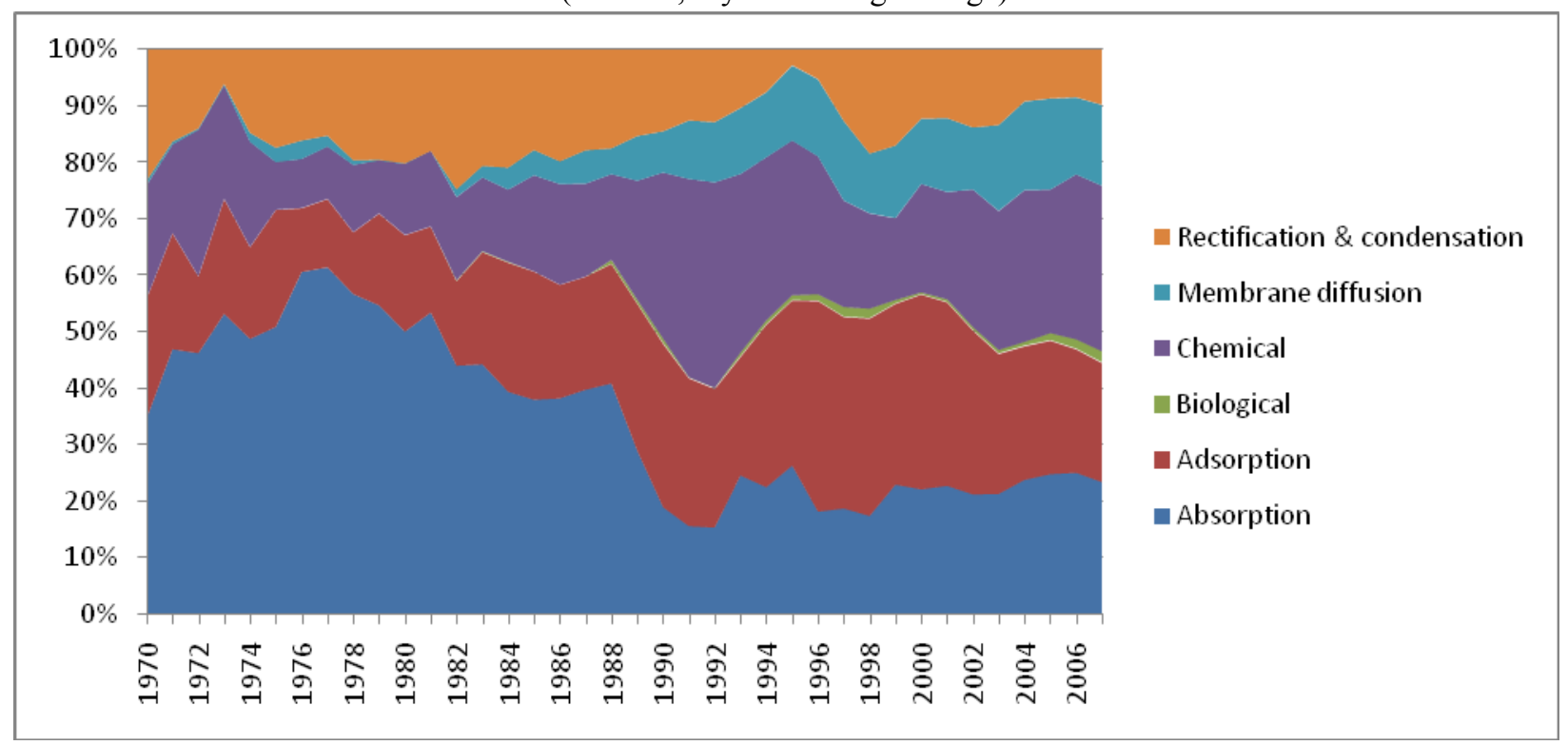

An understanding of the relative maturity of different technologies can be important in policy design.

\section{Evidence across countries}

Aggregating all technology fields, the relative importance of different countries is depicted in Figure 9. Japan, the United States and Germany lead, followed by Korea (which has had exceptionally high growth rates in recent years), and then Great Britain and France. This rank order is more or less true across 
all technology fields (see OECD Patent Statistics Manual, OECD 2009a). However, it is important to bear in mind that there is likely to be a bias toward the inclusion of documents filed at the EPO (since we use ECLA codes in the searches) and from countries in which titles and abstracts are in English (since keyword searches are used).

The first point can be seen by comparing the count of claimed priorities (Figure 9) with counts of all applications deposited at the EPO (Figure 10). There is a strong correlation between the trends for individual inventor country time-series.

Figure 9. Trends in CCMT inventive activity

(Count of CPs worldwide, 3-year moving average, by inventor country)

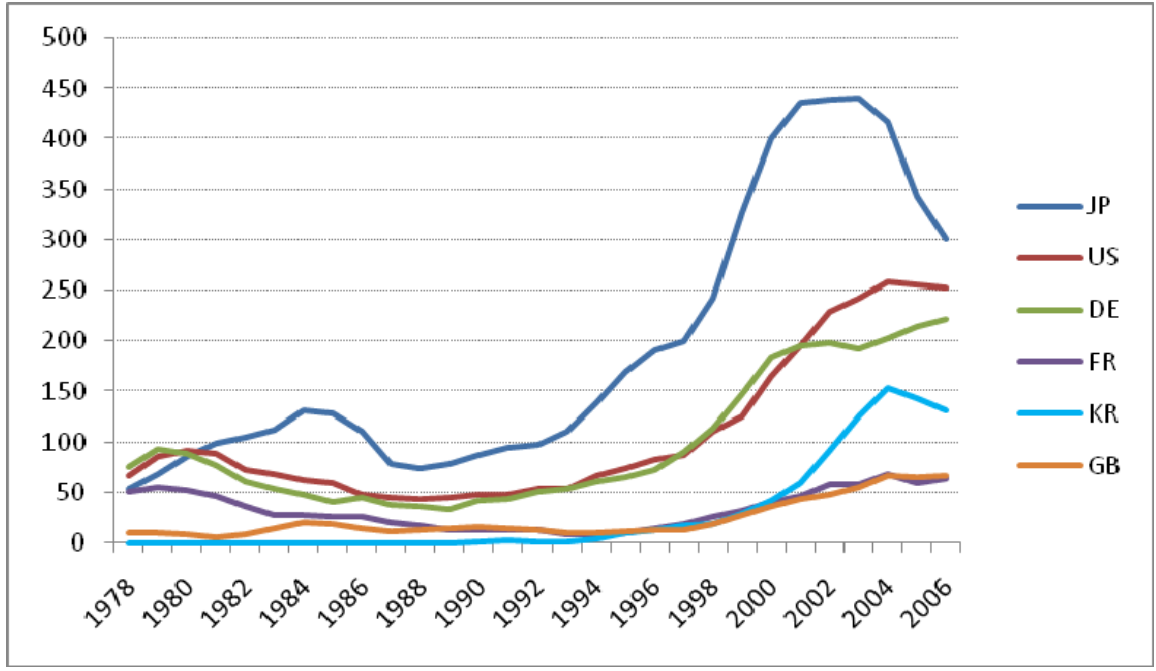

Figure 10. Trends in CCMT inventive activity

(Count of all applications deposited at the EPO, 3-year moving average, by inventor country)

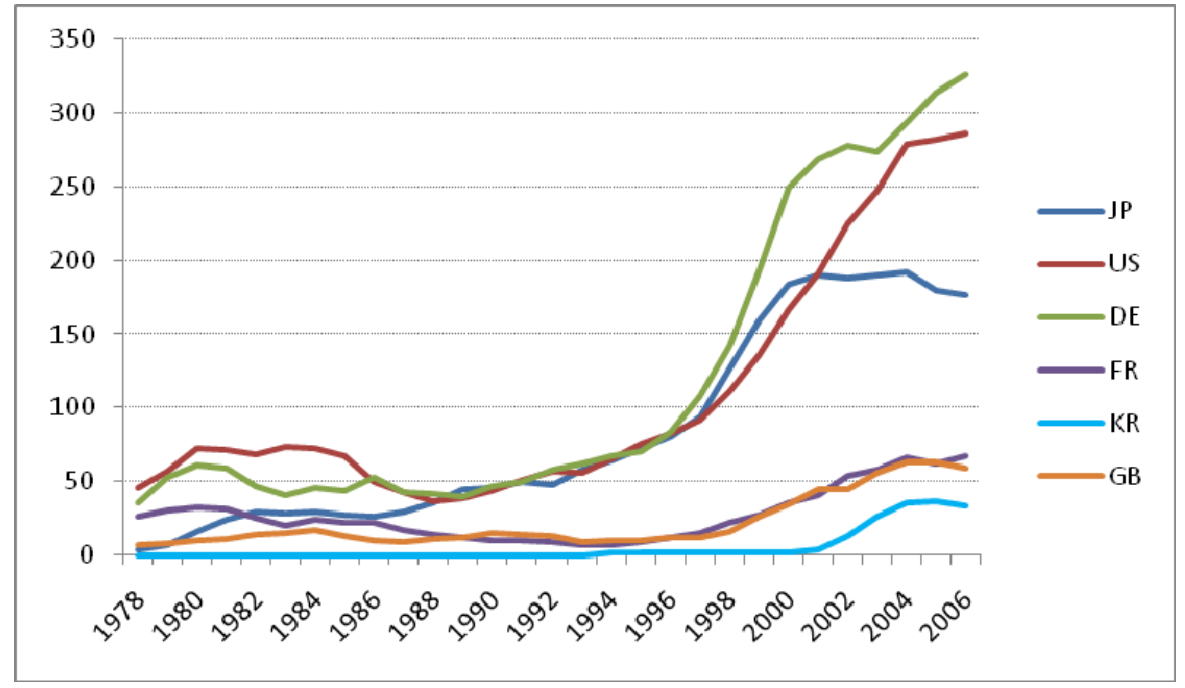

Different countries have specialised in the two types of solar energy. While Japan and the US are dominant in solar PV, Germany and France have played a leading role in solar thermal. Most of the smaller countries have also been more active in solar thermal (e.g. Israel, Spain, and Netherlands). Interestingly, China and India are amongst only four countries in which solar PV inventions exceed solar thermal. 
Figure 11. Inventor countries for solar thermal and solar PV

(\% share of inventions (CPs worldwide), 1978-2007)

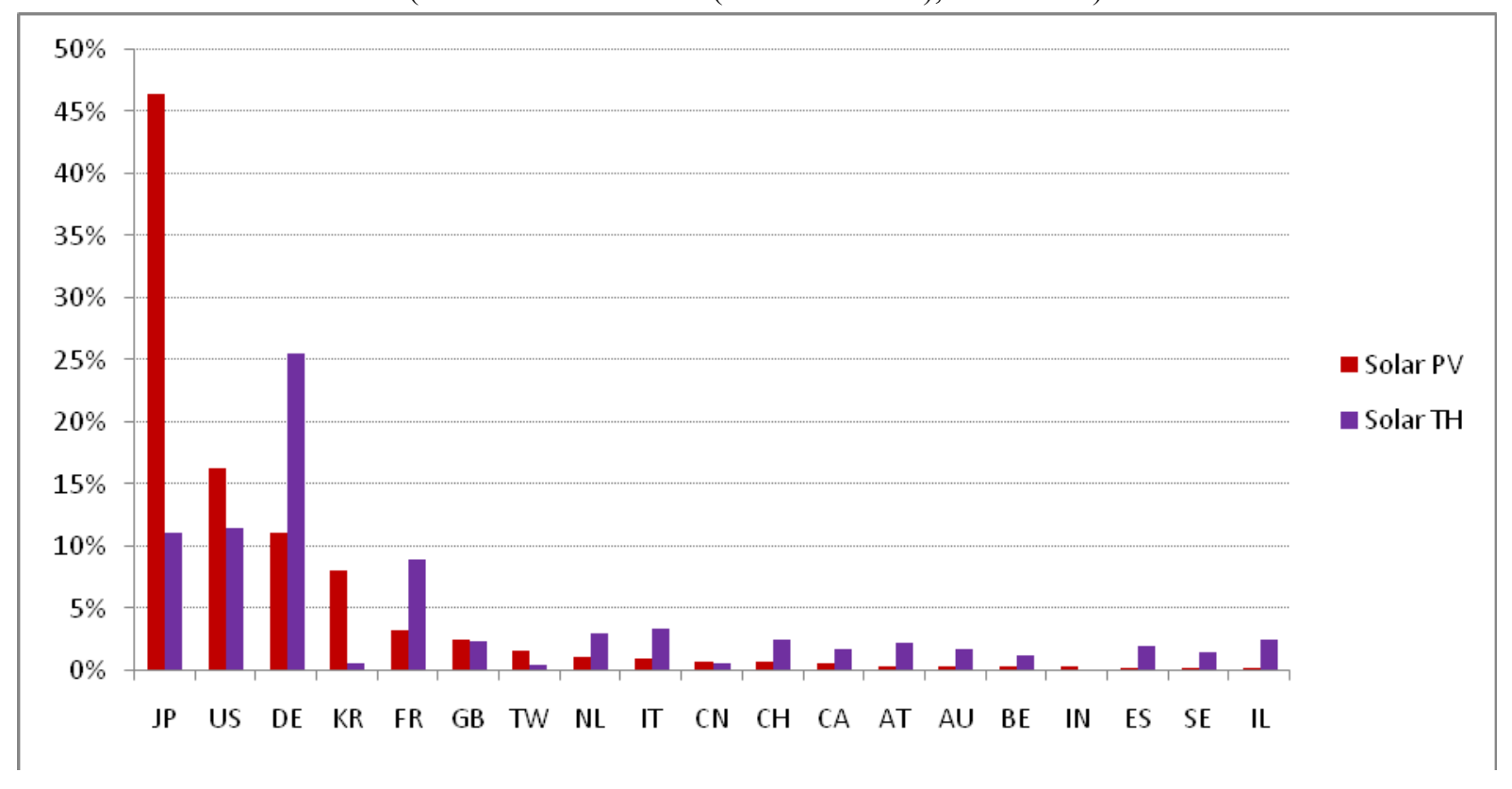

Disaggregating still further we can see trends within PV technologies (see Appendix C ). Two fields DSS cells and solar concentrating have been growing very rapidly in recent years. In solar thermal power it is innovation in mechanical elements (mounting and tracking) which has grown in recent years (Appendix C).

Figure 12 shows the proportion of claimed priority applications that the top five inventor countries comprise. Overall, nearly $80 \%$ of all CCMT CP applications come from Japan, the US, Germany, Korea and France. Approximately one-third comes from Japan, the biggest inventor country. The overall figures are heavily dominated by solar PV, the CCMT category with the largest number of applications. For solar PV, 87\% of CPs are invented by 5 countries (JP, US, DE, KR and FR), with Japan inventing nearly half of all PV CPs. Geothermal is the least concentrated technology field, with just over $60 \%$ of CP patent applications invented by the top 5 inventors, and $20 \%$ by the top inventor country (a similar percentage to biofuels). 
Figure 12. Proportion of patenting (CP) by the top 5 ranking inventor countries for each CCMT field, 19882007

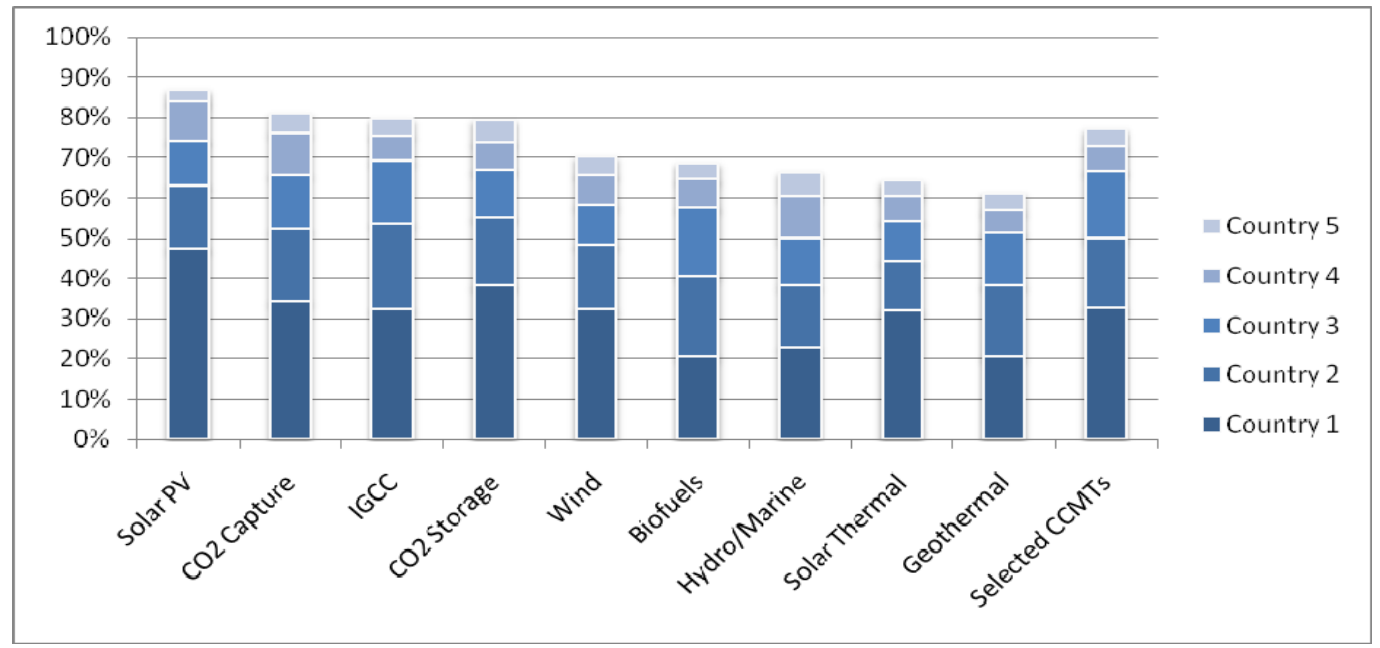

Note: Patent applications with missing inventor countries have been removed when calculating the above proportions.

Table 2 shows the rank of inventor countries. In the 1988-2007 period, Japanese invented patents had the highest number of claimed priorities for all CCMT fields combined, followed by the US, Germany, Korea and France. Japan ranked in the top 3 for all CCMT fields investigated, while the US ranked in the top 2 and Germany in the top 4 for all categories. Korea was ranked fourth overall, but appeared in the top 5 for PV only, the largest category where Korea was ranked fourth. France and Germany were also notable inventors. Some smaller countries also figure in particular fields: Denmark in wind; Finland in IGCC, and Israel in geothermal.

Table 2. Rank of top inventor countries 1988-2007 (counting CP), by CCMT class

\begin{tabular}{|c|c|c|c|c|c|c|c|c|c|c|}
\hline & $\begin{array}{l}\text { Selected } \\
\text { CCMTs }\end{array}$ & $\begin{array}{l}\text { Solar } \\
\text { PV }\end{array}$ & Wind & $\begin{array}{l}\text { Hydro/ } \\
\text { Marine }\end{array}$ & $\begin{array}{c}\text { Solar } \\
\text { TH }\end{array}$ & Biofuels & $\begin{array}{c}\mathrm{CO} 2 \\
\text { Capture }\end{array}$ & $\begin{array}{c}\text { Geo- } \\
\text { thermal }\end{array}$ & IGCC & $\begin{array}{c}\mathrm{CO} 2 \\
\text { Storage }\end{array}$ \\
\hline $\mathrm{JP}$ & 1 & 1 & 3 & 3 & 3 & 3 & 2 & 3 & 2 & 3 \\
\hline US & 2 & 2 & 2 & 1 & 2 & 1 & 1 & 1 & 1 & 1 \\
\hline $\mathrm{DE}$ & 3 & 3 & 1 & 2 & 1 & 2 & 3 & 2 & 3 & 4 \\
\hline KR & 4 & 4 & & & & & & & & \\
\hline FR & 5 & 5 & & 5 & 4 & 4 & 4 & & & 2 \\
\hline GB & 6 & & & 4 & & 5 & 5 & & 4 & \\
\hline IT & 7 & & & & 5 & & & & & \\
\hline CA & 9 & & & & & & & 5 & & 5 \\
\hline DK & 12 & & 4 & & & & & & & \\
\hline ES & 13 & & 5 & & & & & & & \\
\hline $\mathrm{FI}$ & 19 & & & & & & & & 5 & \\
\hline $\mathrm{IL}$ & 20 & & & & & & & 4 & & \\
\hline
\end{tabular}

These ranks have changed over the years. For instance, German's dominance of wind power innovation has grown, while the relative importance of its role in the area of $\mathrm{CO}_{2}$ capture and IGCC (particularly) has decreased over time. Specialisation in individual technology field within CCMT in general is documented in Table 3. Figures in red indicate that the degree of specialisation is amongst the five highest for the field. In some cases this may result in a relatively high \% overall (i.e. solar PV), but in other cases percentage is relatively low since the overall level of activity in these areas (i.e. carbon capture, storage and IGCC) is very limited. 
Table 3. Specialisation of inventor countries in CCMT fields (1988-2007)

\begin{tabular}{|c|c|c|c|c|c|c|c|c|c|c|}
\hline & $\begin{array}{c}\text { Solar } \\
\text { PV }\end{array}$ & $\begin{array}{c}\text { Solar } \\
\text { TH }\end{array}$ & Wind & $\begin{array}{c}\text { Geo- } \\
\text { thermal }\end{array}$ & $\begin{array}{l}\text { Hydro/ } \\
\text { Marine }\end{array}$ & Biofuels & $\begin{array}{c}\mathrm{CO} 2 \\
\text { Capture }\end{array}$ & $\begin{array}{c}\mathrm{CO} 2 \\
\text { Storage }\end{array}$ & IGCC & $\begin{array}{l}\text { Selected } \\
\text { CCMTs }\end{array}$ \\
\hline$J P$ & 84 & 3 & 4 & 1 & 4 & 2 & 2 & 0 & 1 & 100 \\
\hline US & 52 & 7 & 13 & 2 & 15 & 5 & 8 & 1 & 2 & 100 \\
\hline $\mathrm{DE}$ & 39 & 19 & 27 & 2 & 11 & 6 & 3 & 0 & 1 & 100 \\
\hline $\mathrm{KR}$ & 91 & 1 & 4 & 0 & 3 & 1 & 1 & 0 & 0 & 100 \\
\hline $\mathrm{FR}$ & 40 & 15 & 14 & 2 & 17 & 7 & 10 & 1 & 1 & 100 \\
\hline GB & 38 & 8 & 15 & 2 & 31 & 5 & 5 & 0 & 2 & 100 \\
\hline IT & 32 & 19 & 15 & 3 & 28 & 10 & 3 & 0 & 0 & 100 \\
\hline $\mathrm{NL}$ & 41 & 21 & 24 & 4 & 9 & 6 & 6 & 0 & 1 & 100 \\
\hline CA & 22 & 17 & 21 & 5 & 25 & 10 & 7 & 1 & 1 & 100 \\
\hline TW & 82 & 6 & 4 & 1 & 7 & 2 & 0 & 0 & 0 & 100 \\
\hline $\mathrm{CH}$ & 42 & 19 & 9 & 4 & 22 & 7 & 2 & 1 & 3 & 100 \\
\hline DK & 3 & 3 & 86 & 1 & 10 & 2 & 1 & 0 & 0 & 100 \\
\hline ES & 17 & 24 & 52 & 1 & 15 & 3 & 1 & 1 & 0 & 100 \\
\hline $\mathrm{CN}$ & 56 & 9 & 14 & 4 & 10 & 8 & 3 & 0 & 1 & 100 \\
\hline AT & 29 & 25 & 14 & 8 & 27 & 8 & 1 & 0 & 1 & 100 \\
\hline SE & 19 & 15 & 28 & 6 & 29 & 5 & 1 & 0 & 5 & 100 \\
\hline NO & 11 & 10 & 23 & 6 & 45 & 0 & 17 & 2 & 2 & 100 \\
\hline $\mathrm{AU}$ & 36 & 38 & 9 & 1 & 19 & 6 & 3 & 0 & 2 & 100 \\
\hline $\mathrm{FI}$ & 13 & 10 & 22 & 4 & 12 & 31 & 5 & 0 & 8 & 100 \\
\hline IL & 24 & 47 & 11 & 17 & 20 & 4 & 2 & 0 & 4 & 100 \\
\hline $\mathrm{BE}$ & 39 & 15 & 24 & 1 & 9 & 14 & 4 & 0 & 2 & 100 \\
\hline IN & 62 & 2 & 7 & 0 & 2 & 13 & 13 & 1 & 1 & 100 \\
\hline$R U$ & 33 & 25 & 21 & 0 & 19 & 6 & 7 & 0 & 1 & 100 \\
\hline GR & 33 & 42 & 21 & 0 & 34 & 0 & 0 & 0 & 4 & 100 \\
\hline BR & 1 & 0 & 18 & 0 & 59 & 21 & 0 & 0 & 0 & 100 \\
\hline PT & 14 & 36 & 9 & 5 & 31 & 5 & 0 & 5 & 0 & 100 \\
\hline IE & 26 & 5 & 11 & 0 & 46 & 17 & 0 & 0 & 0 & 100 \\
\hline $\mathrm{HU}$ & 8 & 60 & 6 & 25 & 19 & 6 & 0 & 0 & 0 & 100 \\
\hline SG & 86 & 7 & 7 & 7 & 14 & 0 & 0 & 0 & 0 & 100 \\
\hline UA & 7 & 13 & 29 & 0 & 7 & 36 & 7 & 0 & 7 & 100 \\
\hline$N Z$ & 26 & 35 & 8 & 8 & 23 & 8 & 12 & 0 & 0 & 100 \\
\hline HK & 36 & 30 & 21 & 0 & 24 & 0 & 10 & 0 & 0 & 100 \\
\hline TR & 28 & 31 & 15 & 0 & 31 & 0 & 5 & 0 & 0 & 100 \\
\hline $\mathrm{TH}$ & 58 & 53 & 42 & 0 & 0 & 0 & 0 & 0 & 0 & 100 \\
\hline$C Z$ & 18 & 24 & 12 & 12 & 35 & 24 & 0 & 0 & 0 & 100 \\
\hline PL & 2 & 38 & 30 & 0 & 45 & 0 & 0 & 0 & 0 & 100 \\
\hline $\mathrm{MX}$ & 19 & 19 & 0 & 0 & 56 & 6 & 19 & 0 & 0 & 100 \\
\hline
\end{tabular}

Note: The top five countries in each field are shown in bold.

\section{Market Structure}

In this sub-section we review the evidence of market concentration in the different technology fields. It is important to note that a high degree of specialisation at the country level does not necessarily translate into a high degree of market concentration.

The data is generated on the basis of 'assignee' (patent owner) data which is held in PATSTAT. Statistics reported in this Section are based on applicant names from PATSTAT that have been partially 
cleaned (name matching). The data have not been adjusted for changes in company structure (mergers \& acquisitions, etc.).

Figure 13 shows the one-firm, five-firm, and ten-firm concentration ratios for the different technology fields. $\mathrm{CO}_{2}$ storage (for which there are relatively few $\mathrm{CPs}$ ) has the highest concentration with over $36 \%$ of inventions attributable to ten firms. Conversely, for solar thermal the relevant figure is $5 \%$. The figure also includes the concentration ratio for CCMTs overall, with 10 firms accounting for almost $10 \%$ of all CPs. This is closely comparable with concentration observed in conventional (fossil \& nuclear) energy technology fields.

Figure 13. Market concentration (1998-2007)

(\% market share by the first 1,5 and 10 applicants)

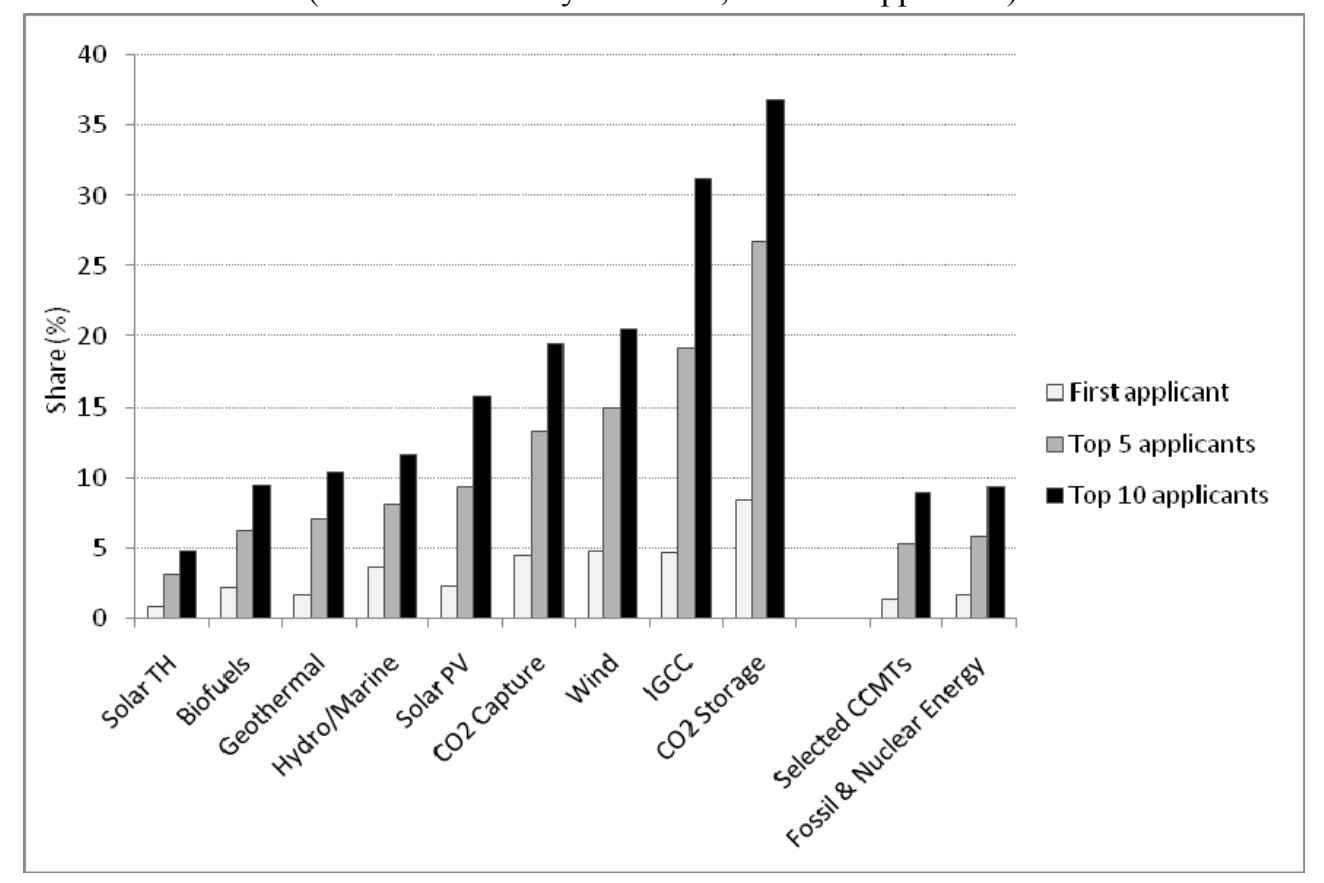

Note: Statistics are based on data on applicant names as they appear in PATSTAT; the data have not been cleaned or harmonized.

Table 4 provides the names of the most important assignees in CCS and IGCC technologies. Concentration has decreased in all areas in the last few years. However, carbon storage (in particular) continues to be dominated by a very small number of firms. Across the three areas there is a split between petroleum firms (e.g. Shell, Exxon), general engineering firms (e.g. Siemens, Schlumberger, General Electric), chemical firms (e.g. AirLiquid, Praxair), and even mineral companies (BHP). Some firms (e.g. Mitsubishi) are important in all areas, and have been for some time, while others have emerged recently. Many of the firms are the same as those found in Lee et al. (2009), but there are some differences. 
Table 4. Major applicants in CCS \& IGCC technologies (1988-2007)

(Number of filings and \% share)

\begin{tabular}{|c|c|c|c|c|c|}
\hline \multicolumn{6}{|c|}{$\mathrm{CO}_{2}$ Capture } \\
\hline 1988-1997 & $\mathrm{n}$ & $\%$ & 1998-2007 & $\mathrm{n}$ & $\%$ \\
\hline BOC GROUP & 157 & $9.7 \%$ & PRAXAIR & 206 & $6.3 \%$ \\
\hline MITSUBISHI & 138 & $8.6 \%$ & AIR LIQUID & 162 & $5.0 \%$ \\
\hline AIR PRODUCTS AND CHEMICALS & 93 & $5.8 \%$ & AIR PRODUCTS AND CHEMICALS & 141 & $4.3 \%$ \\
\hline KANSAI & 78 & $4.8 \%$ & BOC GROUP & 113 & $3.5 \%$ \\
\hline AIR LIQUID & 58 & $3.6 \%$ & SHELL & 100 & $3.1 \%$ \\
\hline PRAXAIR & 53 & $3.3 \%$ & MITSUBISHI & 96 & $3.0 \%$ \\
\hline UNION CARBIDE & 45 & $2.8 \%$ & EXXON & 81 & $2.5 \%$ \\
\hline UOP & 34 & $2.1 \%$ & CECA & 70 & $2.2 \%$ \\
\hline LINDE & 32 & $2.0 \%$ & GENERAL ELECTRIC & 59 & $1.8 \%$ \\
\hline \multirow[t]{2}{*}{ UNITED TECHNOLOGIES CORP. } & 28 & $1.7 \%$ & INSTITUT FRANCAIS DU PETROLE & 57 & $1.8 \%$ \\
\hline & & $44 \%$ & & & $33 \%$ \\
\hline \multicolumn{6}{|c|}{$\mathrm{CO}_{2}$ Storage } \\
\hline 1988-1997 & $\mathrm{n}$ & $\%$ & 1998-2007 & $\mathrm{n}$ & $\%$ \\
\hline MITSUBISHI & 18 & $38 \%$ & SHELL & 98 & $21 \%$ \\
\hline AGRICULTURAL GAS CO & 9 & $19 \%$ & INSTITUT FRANCAIS DU PETROLE & 43 & $9.3 \%$ \\
\hline NKK CORP & 5 & $10 \%$ & TERRALOG & 23 & $5.0 \%$ \\
\hline SEEC INC & 4.5 & $9.4 \%$ & EXXON & 20 & $4.2 \%$ \\
\hline ELECTRIC POWER RESEARCH INST & 2.5 & $5.2 \%$ & SCHLUMBERGER & 18 & $3.9 \%$ \\
\hline BAL AB & 2 & $4.2 \%$ & CDX GAS & 17 & $3.7 \%$ \\
\hline UNION OIL CO. OF CALIFORNIA & 2 & $4.2 \%$ & AIR PRODUCTS AND CHEMICALS & 15 & $3.2 \%$ \\
\hline DANIEL STEWART ROBERTSON & 1 & $2.1 \%$ & DIAMOND QC TECHNOLOGIES & 14 & $3.0 \%$ \\
\hline HEINZ SEBASTIAN, LEIPZIG DE & 1 & $2.1 \%$ & DROPSCONE & 11 & $2.4 \%$ \\
\hline NAUCHNO-TEKHNICHESKIJ TSENTR & 1 & $2.1 \%$ & BHP BILLITON INNOVATION & 8.5 & $1.8 \%$ \\
\hline \multicolumn{4}{|c|}{$96 \%$} & & $57 \%$ \\
\hline \multicolumn{6}{|c|}{ IGCC } \\
\hline 1988-1997 & $\mathrm{n}$ & $\%$ & 1998-2007 & $\mathrm{n}$ & $\%$ \\
\hline MITSUBISHI & 90 & $9.3 \%$ & MITSUBISHI & 57 & $7.8 \%$ \\
\hline AIR PRODUCTS AND CHEMICALS & 82 & $8.5 \%$ & SIEMENS & 56 & $7.7 \%$ \\
\hline EBARA & 80 & $8.3 \%$ & GENERAL ELECTRIC & 54 & $7.4 \%$ \\
\hline HITACHI & 52 & $5.4 \%$ & TEXACO & 46 & $6.2 \%$ \\
\hline FOSTER WHEELER & 47 & $4.9 \%$ & HITACHI & 39 & $5.3 \%$ \\
\hline TEXACO & 42 & $4.4 \%$ & TOSHIBA & 27 & $3.7 \%$ \\
\hline IMATRAN VOIMA & 32 & $3.3 \%$ & ISHIKAWAJIMA HARIMA & 22 & $3.0 \%$ \\
\hline ISHIKAWAJIMA HARIMA & 32 & $3.3 \%$ & NORSK HYDRO & 21 & $2.9 \%$ \\
\hline SIEMENS & 32 & $3.3 \%$ & ALSTOM & 19 & $2.7 \%$ \\
\hline AHLSTROM & 25 & $2.6 \%$ & ORMAT & 19 & $2.6 \%$ \\
\hline & & $53 \%$ & & & $49 \%$ \\
\hline
\end{tabular}

Note: Data on applicant names have been partially cleaned (name matching).

\section{Determinants and Consequences of CCMT Innovation: the Role of Policy}

\section{Determinants of Innovation}

It has long been recognised that the environmental policy framework can affect the rate and direction of innovation in pollution abatement technologies. This argument is an extension of a more general postulate that public policy may induce innovation by changing relative factor prices or introducing production constraints. The idea was first raised by Hicks (1932), who observed that a change in the 
relative prices of factors of production will motivate firms to invent new production methods in order to economise the use of a factor which has become relatively expensive. Since markets often fail to put a price on environmental resources, the opportunity costs of many environmental assets is to a large extent a consequence of government regulation and incentives (see Johnstone and Haščič 2009 and OECD 2009c for recent evidence.)

There are a limited number of empirical studies which have sought to analyse the determinants of patented environmental innovations. An early paper by Lanjouw and Mody (1996), examined the relationship between the number of patents granted and environmental policy stringency, measured in terms of pollution abatement expenditures (PACE) at the macroeconomic level, for Japan, the US, and Germany. For the period 1971-1988, they found that pollution abatement costs affect the number of patents successfully granted, but with a 1-2 year lag.

Using US industry-level data, Jaffe and Palmer (1997) extended Lanjouw and Mody's study, by incorporating various factors that potentially affect environmental innovation. They examined the relationship between stringency and innovation for a set of US manufacturing industries in the period 1977-1989, where innovation was captured in terms of both R\&D expenditures and patents. They found that increased environmental stringency (higher level of PACE) does increase R\&D expenditures. But the study did not support the hypothesis that the number of patents increased in response to environmental regulation.

Brunnemeier and Cohen (2003) built on Jaffe and Palmer's work, by narrowing innovation down to purely "environmental" patents. They used US manufacturing industry data and analysed factors that determined environmental technological innovation. For indicators of policy stringency, they used pollution abatement costs and the number of inspections undertaken by the direct regulatory institutions. Contrary to Jaffe and Palmer, they found that the PACE variable has a significant (and positive) effect on environmental innovation, whereas subsequent monitoring does not.

Taylor et al. (2003) studied the time path of innovation in sulphur dioxide $\left(\mathrm{SO}_{2}\right)$ control, especially activities related to flue gas desulphurisation. Analysing a very long time span (1887-1995), they found that consistently more patent applications were placed after $\mathrm{SO}_{2}$ regulation was introduced in the $1970 \mathrm{~s}$. In addition to $\mathrm{SO}_{2}$ regulation, Popp (2006) also examined $\mathrm{NO}_{\mathrm{X}}$ regulation in the US, as well as the German and Japanese electricity sectors - to explore whether these regulations affected (inter)national innovation and diffusion. One of Popp's main findings was that it is mainly domestic regulation that fosters innovative activities in the home country. But he also found an important role being played by foreign innovation in the development of these patents.

Popp (2003) examined the effects of the introduction of the tradable permit system for $\mathrm{SO}_{2}$ emissions as part of US Clean Air Act Amendments on the technological efficiency of flue-gas desulphurisation. Comparing patent applications after the introduction of the tradable permit scheme with those submitted under the previous technology-based regulatory system, he found evidence of the improved removal efficiency of scrubbers.

Crabb and Johnson (2007) assessed the effects of fuel prices (and thus taxes) on innovation in automotive energy-efficient technologies in the US in the period 1980-1999. Using USPTO patent classes, they found that applications for patents on relevant automotive products and processes were induced by increases in domestic "wellhead" extraction costs (but not by increases in the import price of oil or the price of gasoline). This is consistent with the induced innovation hypothesis, if it is assumed that domestic sources can substitute for imported oil, at least temporarily.

As a preliminary indicator of the effect of public policy on innovation in CCMTs, Figure 14 presents the aggregate data on CCMT claimed priorities indexed on the year of the signing of the Kyoto Protocol 
(1997). As can be seen, in this period there is a marked increase in the rate of patenting for CCMT technologies, while general patent levels are unaffected and fossil fuel patents actually begin to decrease soon thereafter.

Figure 14. Growth rate of CCMT patenting

(Count of CPs worldwide, 3-year moving average, indexed on 1997=1.0)

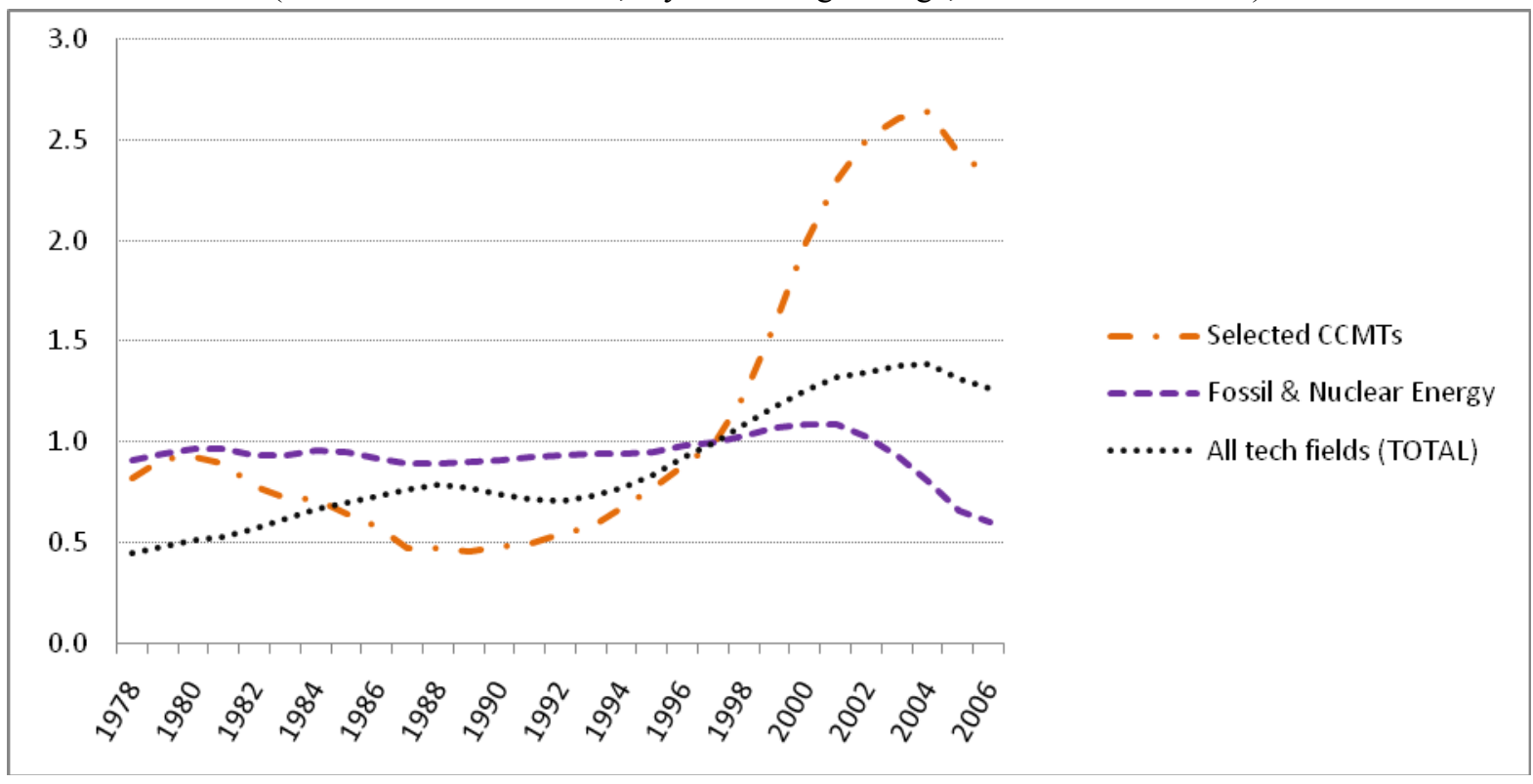

The technology fields are disaggregated in Figure 15 below. There was a marked 'take-off' in wind, solar PV, and hydro/marine innovation after Kyoto. To a lesser extent this is also true of biofuels and geothermal innovation. IGCC has actually fallen.

Figure 15. Growth rate of CCMT patenting

(Count of CPs worldwide, 3-year moving average, indexed on 1997=1.0)

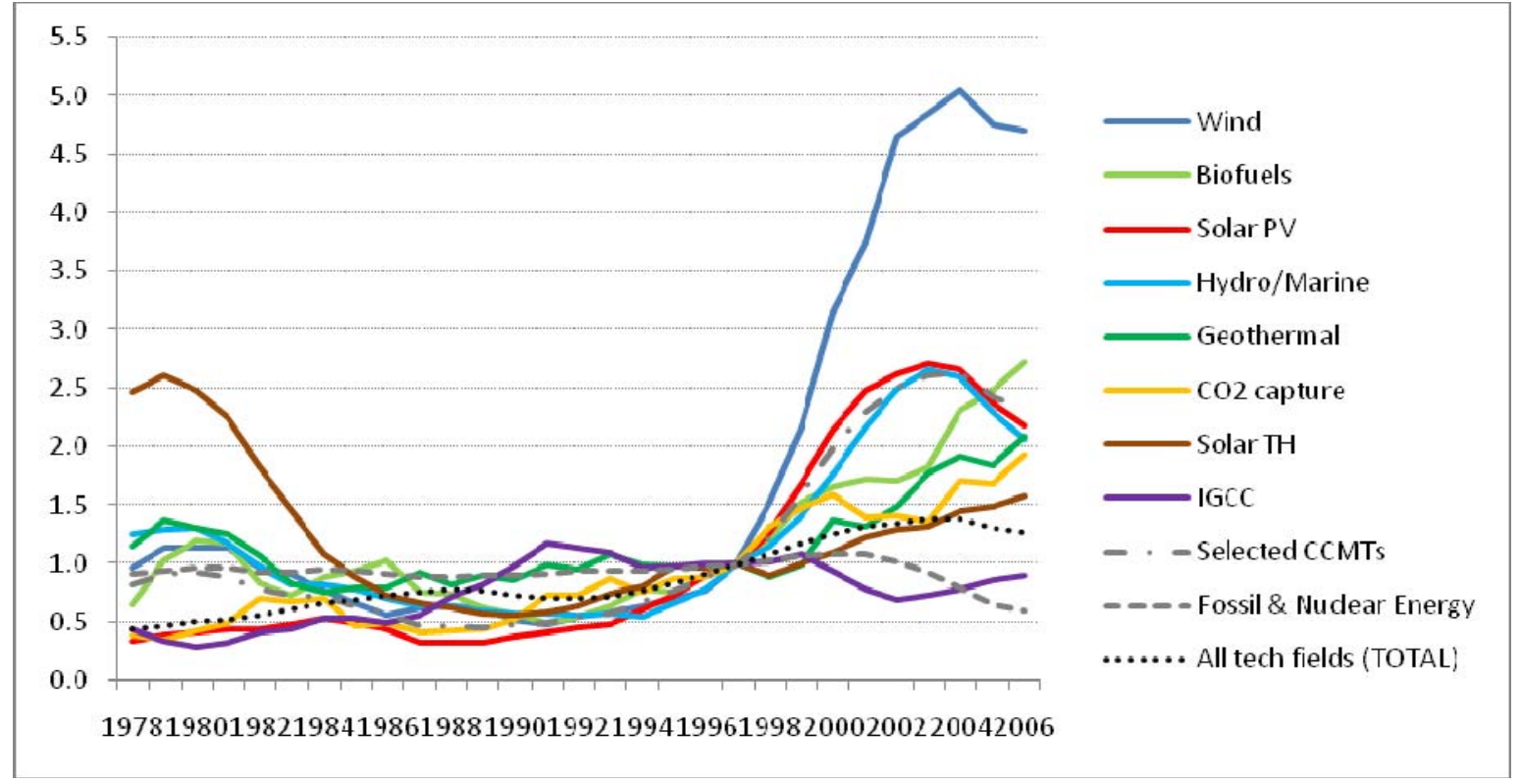

This highlights the importance of looking at the determinants of innovation in a more comprehensive manner, taking into account all policy and market factors. For instance, general market conditions can also 
play an important role since in many cases the achievement of environmental objectives is complementary with efforts to improve the efficiency of production more generally (i.e. the environment is an 'impure' public good). In the case of climate change mitigation technologies (CCMT), the price of oil is likely to be an important influence, and the relationship between CCMT patenting and crude oil prices is shown in Figure 16.

Figure 16. Crude oil prices (2006 USD) and biofuels patenting (CP)

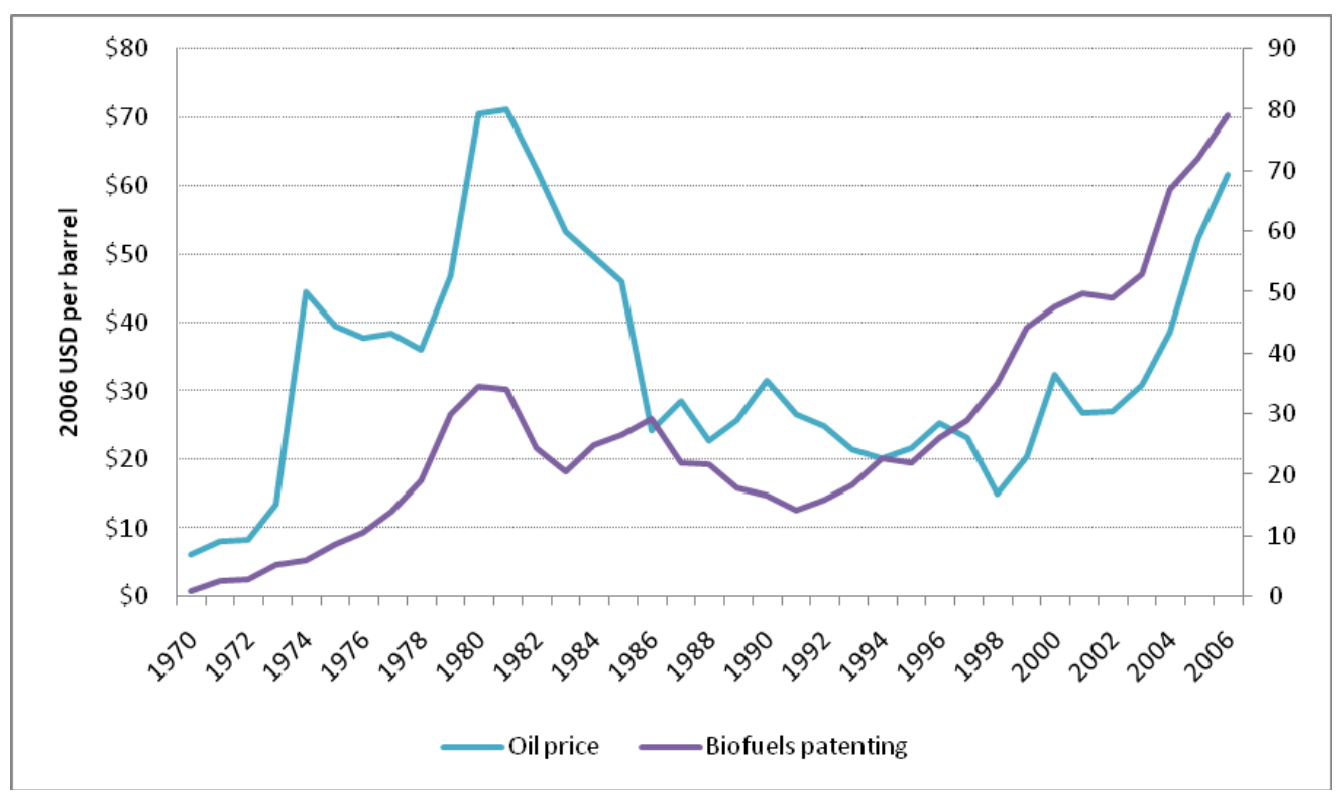

It is, however, important to look at how individual countries have sought to encourage renewable energy use and innovation in a more disaggregated manner. Figure 17 shows the relationship between government expenditures on energy technology R\&D and countries' inventive activity, for the three major inventing countries (DE, JP, US). It suggests that while R\&D budgets dedicated to traditional energy sources have generally decreased, government $R \& D$ spent on renewables has remained more-or-less stable. Indeed, patenting activity in CCMT has been much greater than in conventional fossil-fuel and nuclear energy sectors. However, without further analysis it is difficult to draw conclusions about the role of government $R \& D$ relative to other determinants that may encourage inventive activity. 
Figure 17. Patenting Activity and Government Expenditures on Energy Technology R\&D (indexed on 1978=1.0)

a. Germany

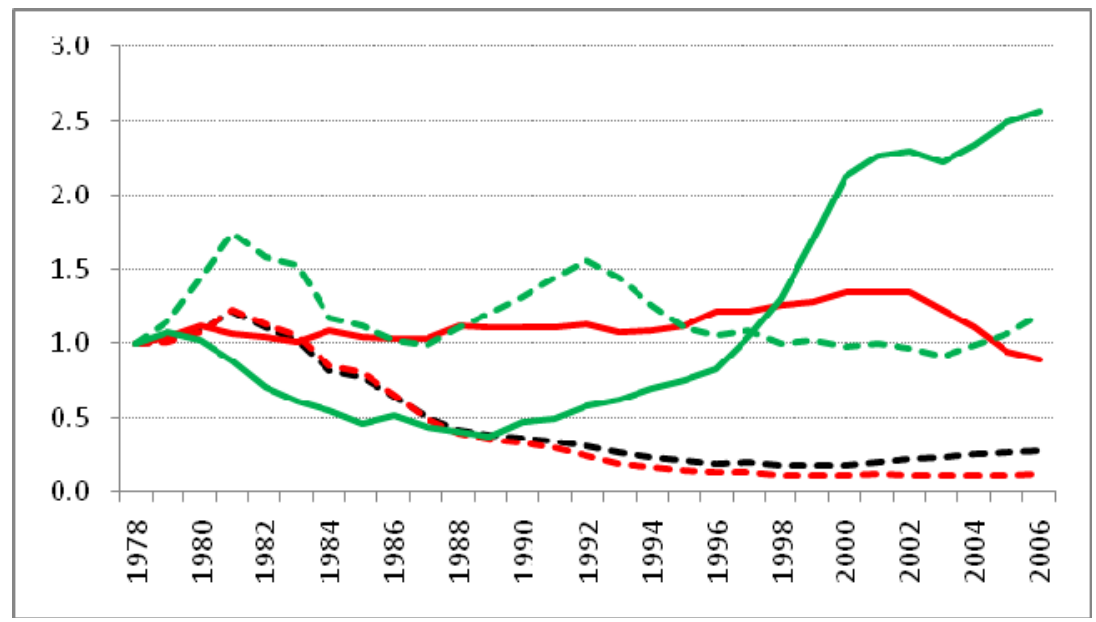

b. Japan

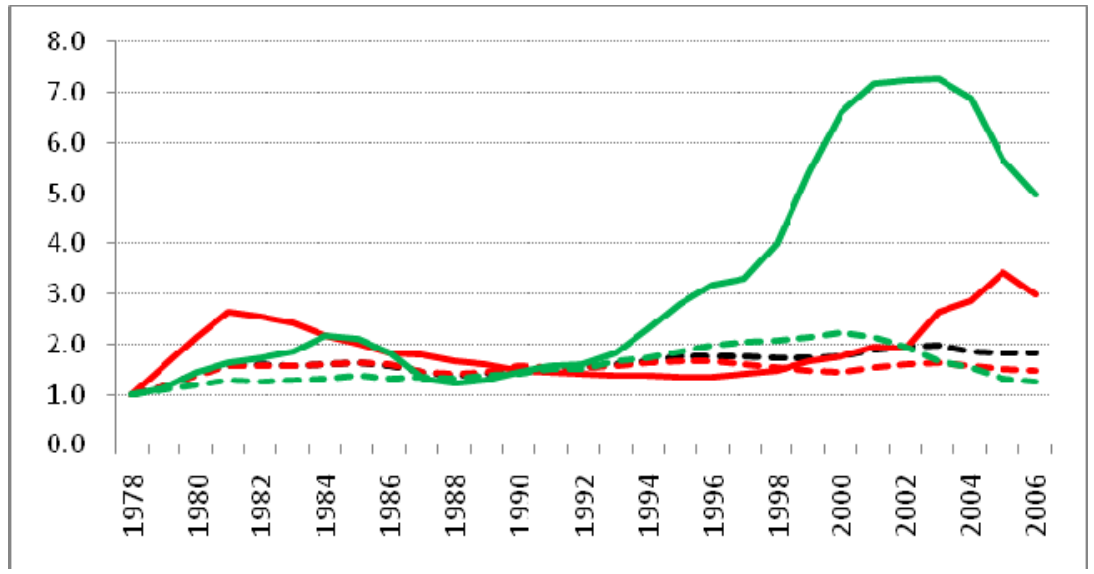

c. United States

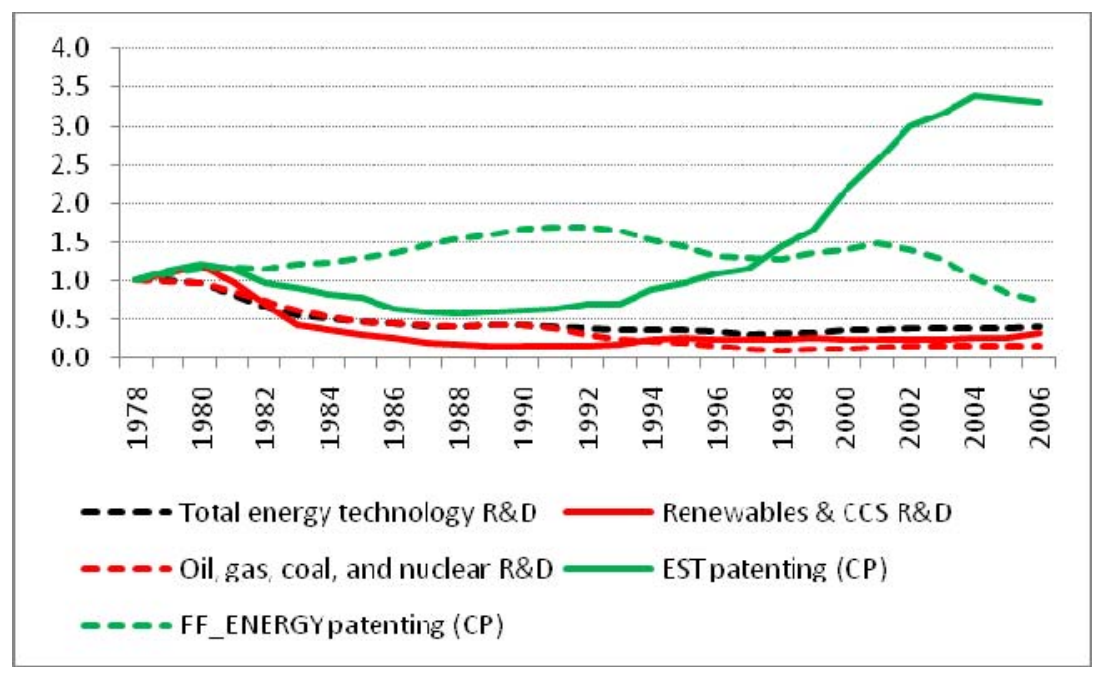


Indeed, more disaggregated data on $R \& D$ budgets suggest that the role of $R \& D$ varies by technological field (Table 5). While the correlation between dedicated energy R\&D and patenting is rather high at the aggregated level (TOTAL, F\&N_ENERGY, and CCMT), the correlation is much less for the individual CCMT fields (with the exception of $\mathrm{CO}_{2}$ capture).

Table 5. Correlation between CCMT patenting and specific R\&D expenditures

(Number of CCMT claimed priorities worldwide by inventor country and priority year; IEA's Energy Technology $R \& D$ expenditures by country and year)

\begin{tabular}{lll}
\hline \multicolumn{3}{c}{ Pearson correlation coefficients } \\
\hline Solar PV & Solar PV R\&D & 0.52 \\
Solar TH & Solar TH power R\&D & 0.34 \\
Wind & Wind power R\&D & 0.31 \\
Geothermal & Geothermal R\&D & 0.28 \\
Biofuels & Bio-energy R\&D & 0.48 \\
$\mathrm{CO}_{2}$ capture & $\mathrm{CO}_{2}$ capture R\&D & 0.77 \\
$\mathrm{CO}_{2}$ storage & $\mathrm{CO}_{2}$ storage R\&D & 0.18 \\
$\mathrm{CCMT}$ & $\mathrm{Renewables} \mathrm{R \& D}$ & 0.38 \\
$\mathrm{CCMT}$ & Total Energy R\&D & 0.61 \\
F\&N Energy & Total Energy R\&D & 0.72 \\
TOTAL & Total Energy R\&D & 0.69 \\
\hline
\end{tabular}

In addition to public sector investment in R\&D related to renewable energy, OECD governments have, of course, introduced a wide variety of measures in support of their increased penetration in the market. Based on data collected by the IEA, Figure 18 presents a chronology of the implementation policy measures in different IEA countries. Significant changes have occurred in the public policy framework put in place to support renewable energy. Initially $R \& D$ programs were introduced in a number of countries. This was followed by investment incentives, and later, tax incentives and preferential tariffs. Next, voluntary programs were developed. More recently, quantitative obligations, and finally tradable certificates, have been applied. 
Figure 18. Introduction of renewable energy policies by type in OECD countries

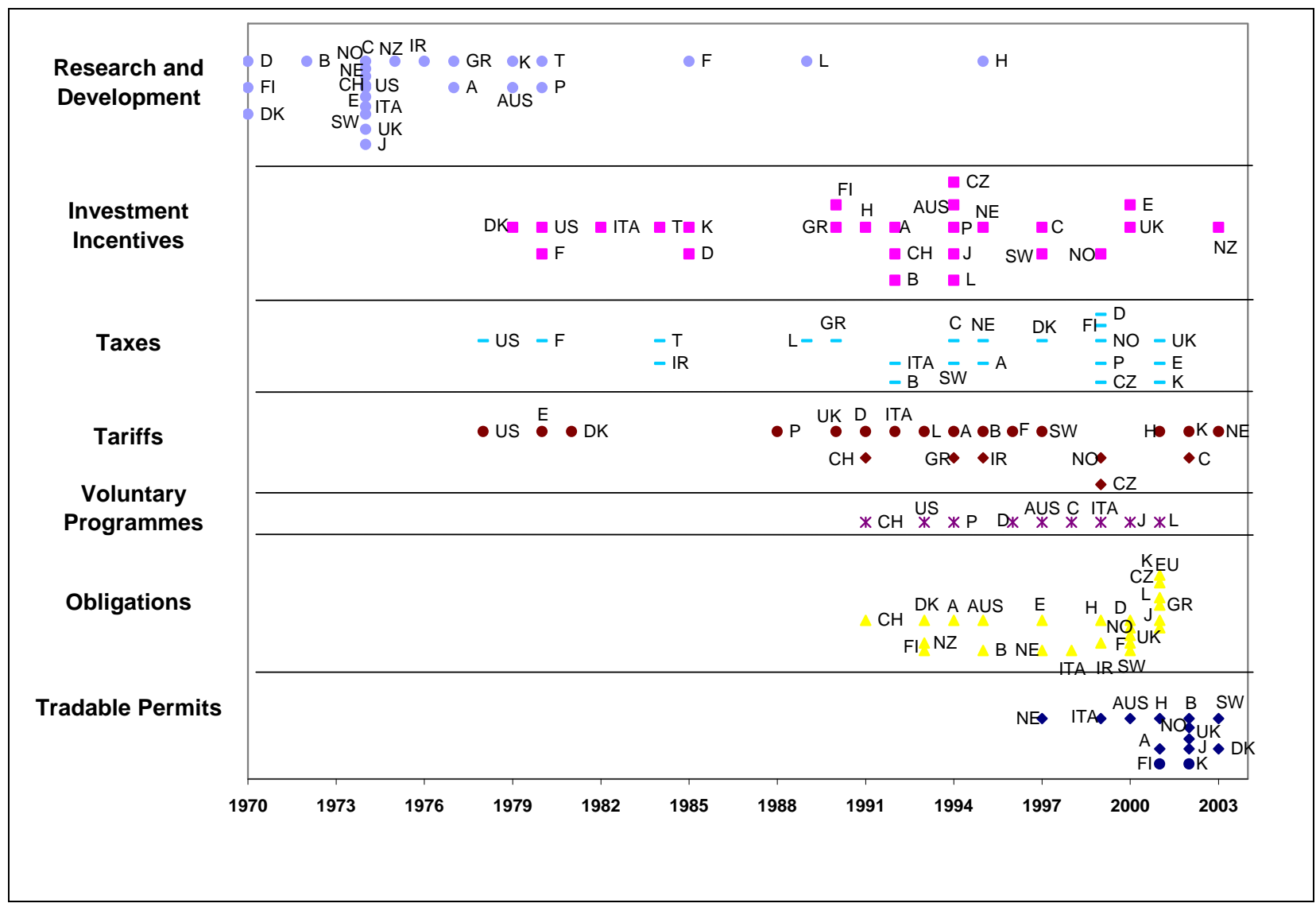

In recent years, renewable energy certificates (some of which are tradable) and feed-in tariffs have become the most important measures to support renewable energy. At the descriptive level, the relationship between renewable energy certificate targets and CCMT patenting is not evident (see Appendix D). While there is a close relationship for some countries (e.g. Italy, Great Britain, and the US) this is not always the case. Similarly, there is no obvious distinction between groups of countries which have introduced feed-in tariffs and the rate of innovation in PV technologies (Appendix D).

However, in a more formal econometric study Johnstone, Haščič and Popp (2010) examine the effects of public policies on innovation in the area of renewable energies for a cross-section of OECD countries over the period 1978-2006. They do find that measures such as feed-in-tariffs and renewable energy certificates have induced innovation. However, this varies by type of renewable. Using the patent counts developed with the EPO a similar analysis is undertaken. ${ }^{14}$

On the basis of this work, it would appear that the most important factor in determining innovation in renewable energy is general innovation capacity (as reflected in the count of patents for all technology fields), shown in Figure 19. Interestingly, the price of electricity - used as a proxy for the cost of electricity from fossil fuel generation - is only significant for wind power. This may reflect the relatively high competitiveness of wind power relative to other renewable energy sources.

\footnotetext{
${ }^{14}$ See also ENV/EPOC/WPNEP(2010)6/FINAL for evidence on determinants of innovation in alternative-fuel vehicles.
} 
Figure 19. Effect of Different Factors on Renewable Energy Patents (CPs)

(elasticities at means)

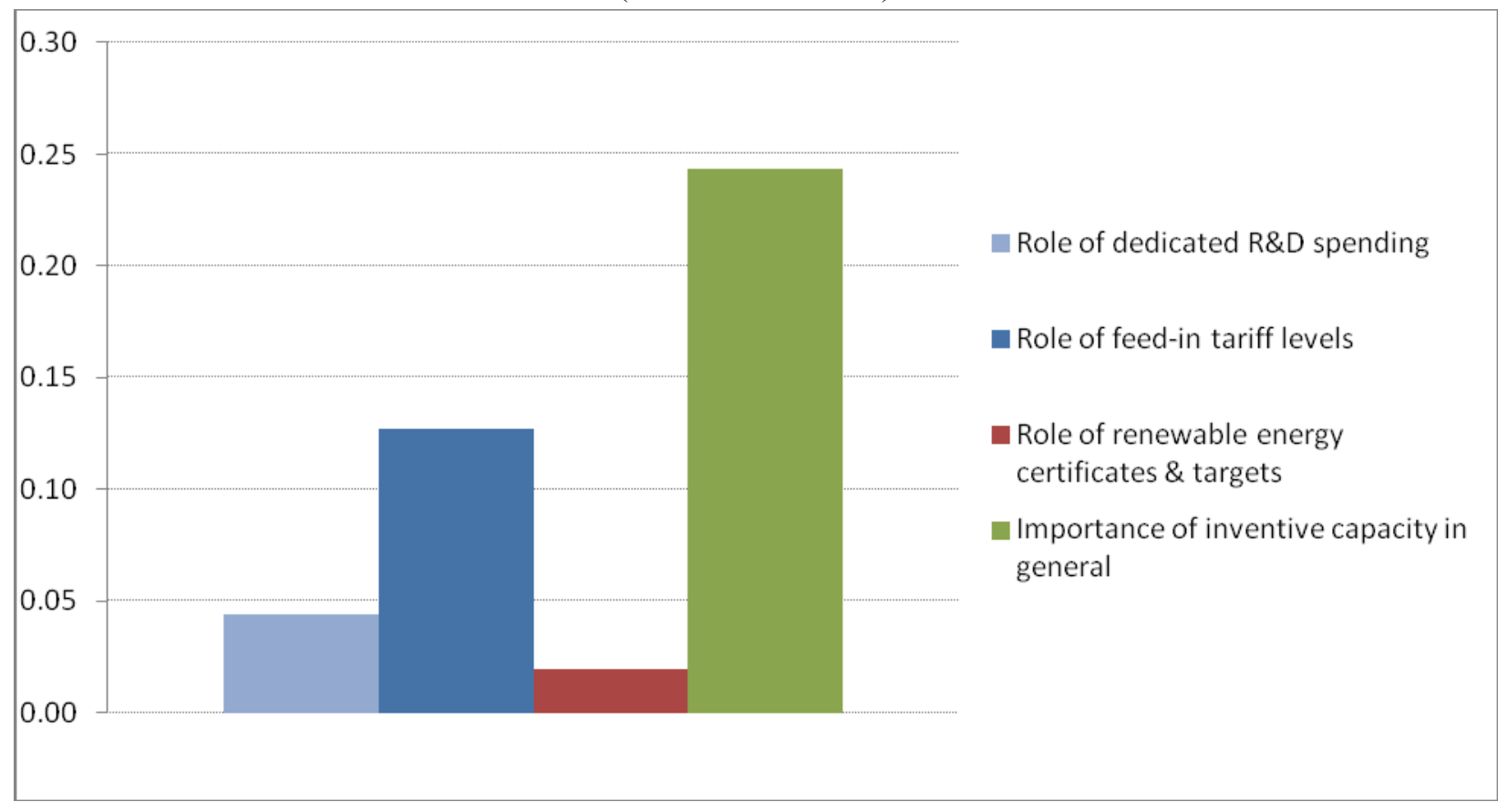

However, public policy has had an effect on the development of new technologies in the area of renewable energy. Public expenditures on $R \& D$ have a positive and significant effect on innovation in renewable energy innovation, although the effect is quite small relative to general innovation capacity - a $1 \%$ increase in targeted public expenditures on R\&D results in a $0.05 \%$ increase in patent counts. The role of feed-in tariffs is much greater than that of renewable energy certificates. However, since the latter have generally been introduced more recently, a longer time series may be required to tease out the relative effect of the two instruments.

Moreover, source-specific models indicate that there is variation in the effects of instrument type on different types of renewable energy. As governments place increasing emphasis on developing a portfolio of energy alternatives, understanding these differences is important for policy design. In particular there appears to be a difference between the influence of feed-in tariffs and REC targets by type of renewable. For instance, RECs are shown to have a greater impact on wind power, while feed-in tariffs have a stronger impact on solar power. This may be due to policy design (see figures $20 \& 21]$.

By guaranteeing a set price that can be differentiated by technology, feed-in tariffs establish a market even for technologies with high costs, such as solar energy. Conversely, REC targets generally allow producers the choice of which technology they will use to comply, making low-cost renewable sources more attractive than high-cost sources. While the results are interesting and robust, further work in the area could be undertaken. This includes accounting for variation in natural conditions as determinants of patenting in renewable energy technologies. 
Figure 20. Effect of Renewable Energy Certificates on Renewable Energy Patents (CPs) (elasticities at mean values)

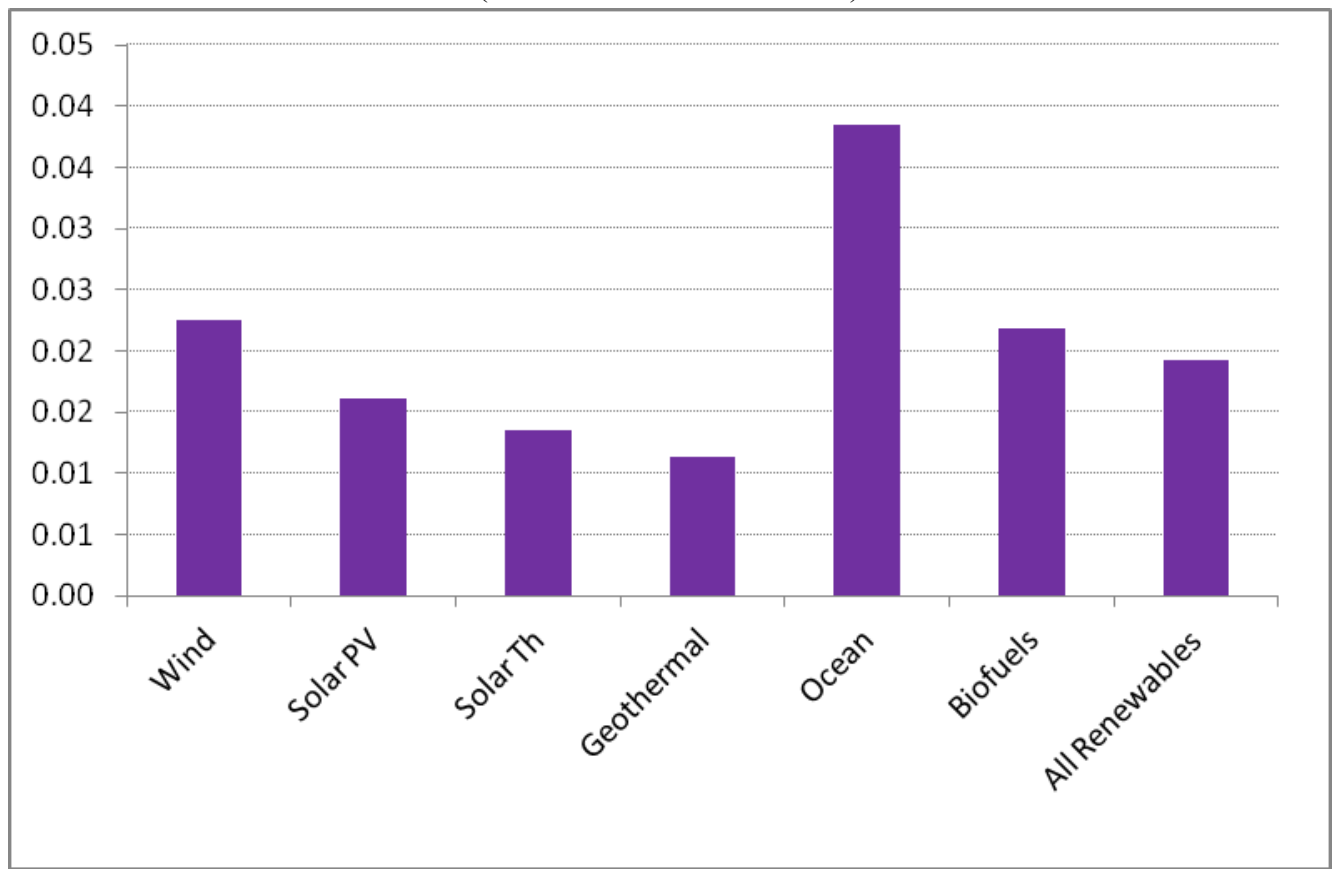

Figure 21. Effect of Feed-in Tariffs on Renewable Energy Patents (CPs) (elasticities at mean values)

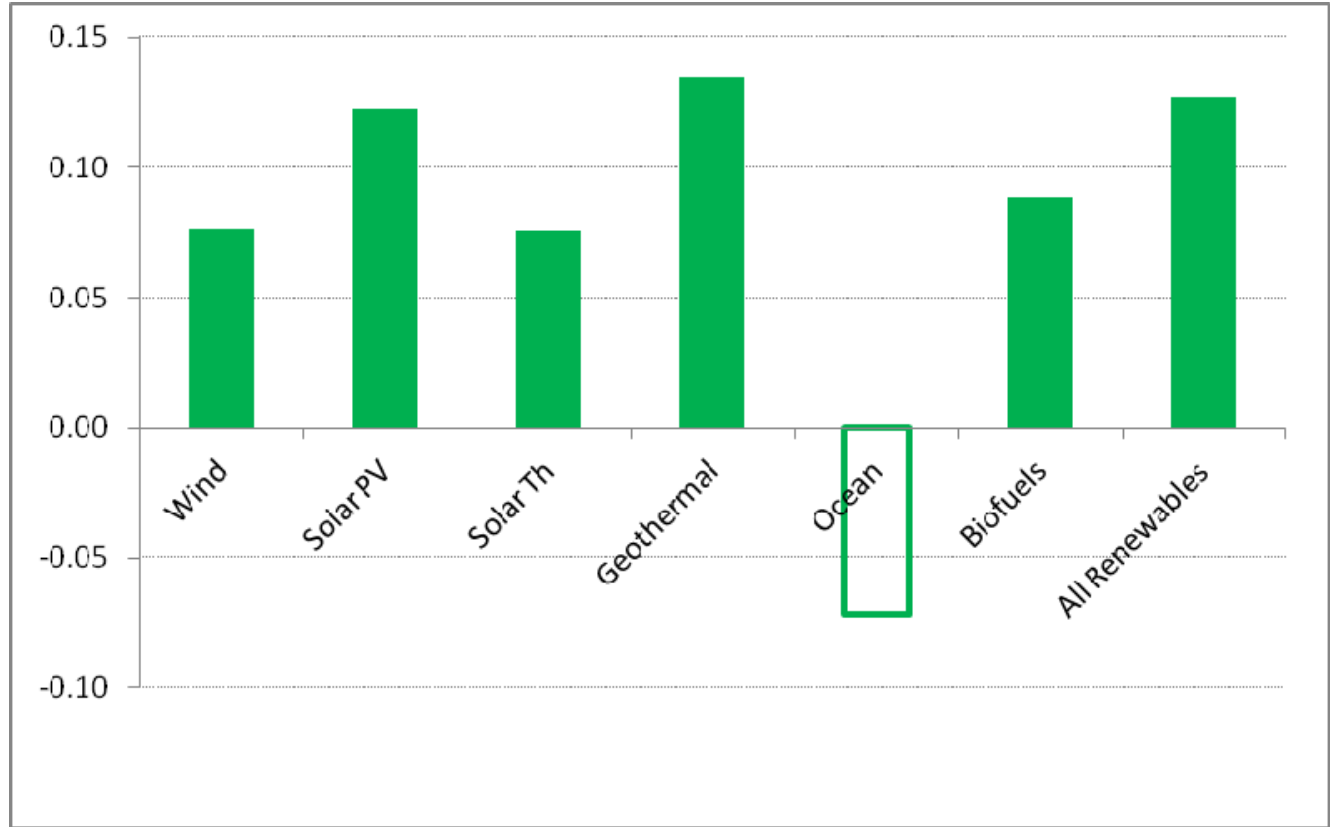




\section{Consequences of Innovation}

Innovation is not an end in itself. Consequently, the role that such patenting activity has had on downstream economic and environmental outcomes should be examined. In principle, innovation leads to knowledge stocks, which leads to reduced costs and consequently increased penetration of renewables and lower GHG emissions. Popp et al. (2010) ${ }^{15}$ evaluate the determinants of investments in wind, solar photovoltaic, geothermal, and electricity from biomass \& waste across 26 OECD countries from 19912004. The knowledge stock is created as the discounted sum of cumulative patent counts for each technology field. This gives an indicator of the global technological frontier.

The conclusions of this work are:

1. Technological advances do lead to greater investment, but the effect is small. For instance, a 10 percent increase in the knowledge stock increases investment in wind and biomass by a little less than one percent. While this small effect may be surprising, it is consistent with findings in the climate policy modelling literature that show induced technological change playing a lesser role than policy-induced substitution (e.g. Nordhaus 2002; Bosetti et al. 2007).

2. However, the effect for some other renewable energy sources is much greater. For instance, in the case of solar PV technologies, a 10 percent increase in knowledge results in a 5 percent increase in investment.

3. Environmental policy appears more important, as countries that have ratified the Kyoto Protocol invest in more renewable capacity. Ratifying the Kyoto Protocol increases investment as much as a 21 percent increase in knowledge.

4. The primary driver behind renewable investments appears to be the requirement to reduce carbon emissions. Investment in other carbon-free energy sources, such as hydro and nuclear power, serve as substitutes for renewable energy. Countries making greater use of nuclear and hydro power have less investment in renewable capacity. In contrast, energy security concerns appear less important, as neither the natural resource base of a country, nor the percentage of energy imported by a country have statistically significant effects.

On-going work is examining the effects of knowledge stocks on other key environmental outcomes such as changes in the efficiency of fossil fuel combustion and in $\mathrm{CO} 2$ emissions over time.

\section{Technology Transfer, Knowledge Spillovers and Research Co-operation}

The international diffusion of mitigation technologies and knowledge is key to addressing transfrontier and global environmental problems. In the case of a global public "bad" (such as global warming) all countries benefit from increased greenhouse gas mitigation arising out of the wide international diffusion of climate change mitigation technologies and knowledge (see Haščič and Johnstone 2011 for a discussion). Indeed, in the debate surrounding the recent climate talks it was apparent that achieving an effective global response to the climate change problem will necessitate significant involvement of nonOECD developing countries in mitigation efforts.

\footnotetext{
${ }^{15}$ Note that the counts used in this work are slightly different from those presented in this report.
} 
ENV/WKP(2010)16

\section{International Transfer of CCMT Inventions}

The potential to use patent data as the base from which to develop a proxy measure of technology transfer arises from the fact that protection for the invention may be sought in a number of countries. ${ }^{16}$ While the vast majority of inventions are only patented in one country (often that of the inventor, particularly for large countries), some are patented in several countries (i.e. the "international patent family size" is greater than one). Such "duplicate" applications can then be used to develop indicators of technology transfer. Of course, patents only give the applicant protection from potential imitators. It does not reflect actual transfer of technologies. If applying for protection did not cost anything, inventors might patent widely and indiscriminately.

However, patenting is costly - both in terms of the costs of preparation of the application and in terms of the administrative costs and fees associated with the approval procedure. [See Helfgott 1993 for some comparative data. Van Pottelsberghe and Francois (2006) also provide more recent data for European Patent Office applications.] If enforcement is weak, the publication of the patent in a local language can also increase vulnerability to imitation (see Eaton and Kortum 1996 and 1999). As such, inventors are unlikely to apply for patent protection in a second country unless they are relatively certain of the potential market for the technology that the patent covers.

Unfortunately, our understanding of patterns of technology transfer remains limited. ${ }^{17}$ In one of the few papers to model the international diffusion of technologies, Eaton and Kortum (1996) modelled the probability that a claim for a patented invention originating in a particular country would be filed in another country. Amongst the determinants they included geographic distance between the countries and the level of trade between the countries, as well as the level of human capital in the 'adopting' country. They find that diffusion falls rapidly with geographic distance.

In the environmental sphere, Constantini and Crespi (2008) find that environmental stringency in the inventing countries and adopting countries are significant determinants of trade in renewable energy technologies and inputs and energy efficiency technologies. However, the measure of environmental stringency used ( $\mathrm{kg}$ of $\mathrm{CO}_{2}$ per unit of GDP) is, at best, a proxy. Moreover, the use of trade data to measure technology transfer for 'environmental' technologies is constrained by the relatively crude nature of the classification system (Harmonised System 1996), resulting in significant measurement error (OECD 2009b). Irrespective of the classifications adopted to develop the measure of trade, a large percentage of the trade flows measured are not related to climate change mitigation. In addition, a number of important technologies which are related to climate change mitigation are not included.

Drawing upon a database of patent applications from a cross-section of countries evidence is provided by Johnstone and Haščič (2011) for the positive effect of environmental policy 'flexibility' on the propensity for the inventions induced to be diffused widely in the world economy. For a given level of policy stringency, countries with more flexible environmental policies are more likely to generate innovations which are diffused widely and are more likely to benefit from innovations generated elsewhere.

A set of influential papers has examined the role of the Clean Development Mechanism within the Kyoto Protocol, which was designed in part to support the diffusion of technologies to non-Annex 1 countries in an effort to accelerate efforts to mitigate climate change. Its success in encouraging such transfer remains an open question (see e.g., Dechezlepretre et al. 2008; Seres, Haites and Murphy 2009;

\footnotetext{
${ }^{16}$ See Appendix E for a discussion of the reliability of the use of duplicate patent applications as a measure of technology transfer.

${ }^{17}$ See Keller (2002) and Keller (2004) for evidence.
} 
Haites et al. 2006; de Coninck et al. 2007). These studies analyse project-level data and conclude, among other things, that technology transfer is more likely to feature in larger CDM projects or projects involving foreign parties (Dechezlepretre et al. 2008; Seres, Haites and Murphy 2009).

Haščič and Johnstone (2011) examine the effect of the Kyoto Protocol's Clean Development Mechanism on the international transfer of wind power technologies. The analysis is conducted using patent data on over 100 countries during a 20 -year period from 1988 to 2007. It is found that public policy plays a significant role in determining technology transfer. In particular, it is found that transfers from Annex 1 countries to non-Annex 1 countries are significantly affected by involvement with the Clean Development Mechanism. However, the effect of CDM is small compared to those of other factors such as domestic absorptive capacity.

The finding that recipient country absorptive capacity plays a key role in encouraging transfer is confirmed in a study (Fisher-Vanden et al. 2006) of the determinants of energy productivity in China's industrial sector. Based on data from approximately 2500 medium- and large-sized industrial facilities, they find that the firms' in-house technology development activities are important for creating the absorptive capacity required for the successful diffusion of imported technology'. This result is consistent with an analysis of CDM-project level data for China, Brazil, India and Mexico undertaken by Dechezleprêtre et al. (2009), although they note differences across countries.

One measure of the extent of 'transfer' is 'family' size, which indicates the number of offices in which protection for a particular invention has been sought. Using the data extracted for this report, In Figure 22 the change in family size for CCMT technologies is presented, along with that for patents in general. The two correlate very highly.

Figure 22. Average Family Size

(Conditional AFS $=($ DUPL + CP $) / C P$ worldwide, 3 -year moving average $)$

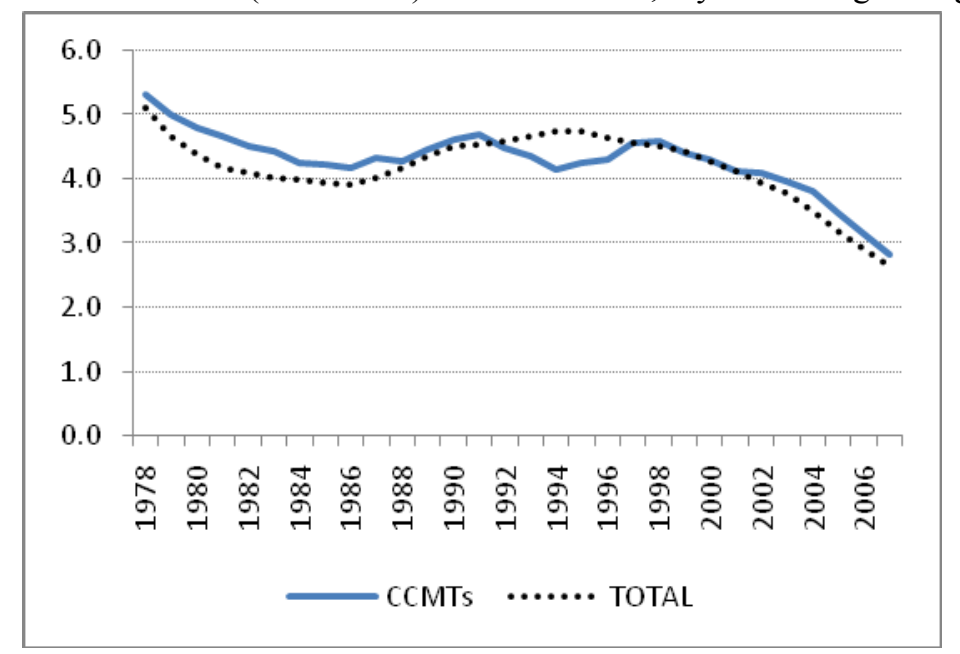

Note: The statistic for average family size shown here is calculated as the mean number of simple patent family members, given that the family size $>1$; hence, "conditional AFS". This is because the decision to 'file abroad' (the first foreign filing) is conceptually different from the decision in how many countries to file (additional foreign filings).

In terms of specific technology fields, however, there is variation. For instance, in the case of $\mathrm{CO}_{2}$ storage family size has been increasing rapidly. On the other other hand, IGCC family size has fallen in recent years (see Figure 23). 
Figure 23. Average Family Size

$($ Conditional AFS $=($ DUPL $+\mathrm{CP}) / \mathrm{CP}$, worldwide $)$

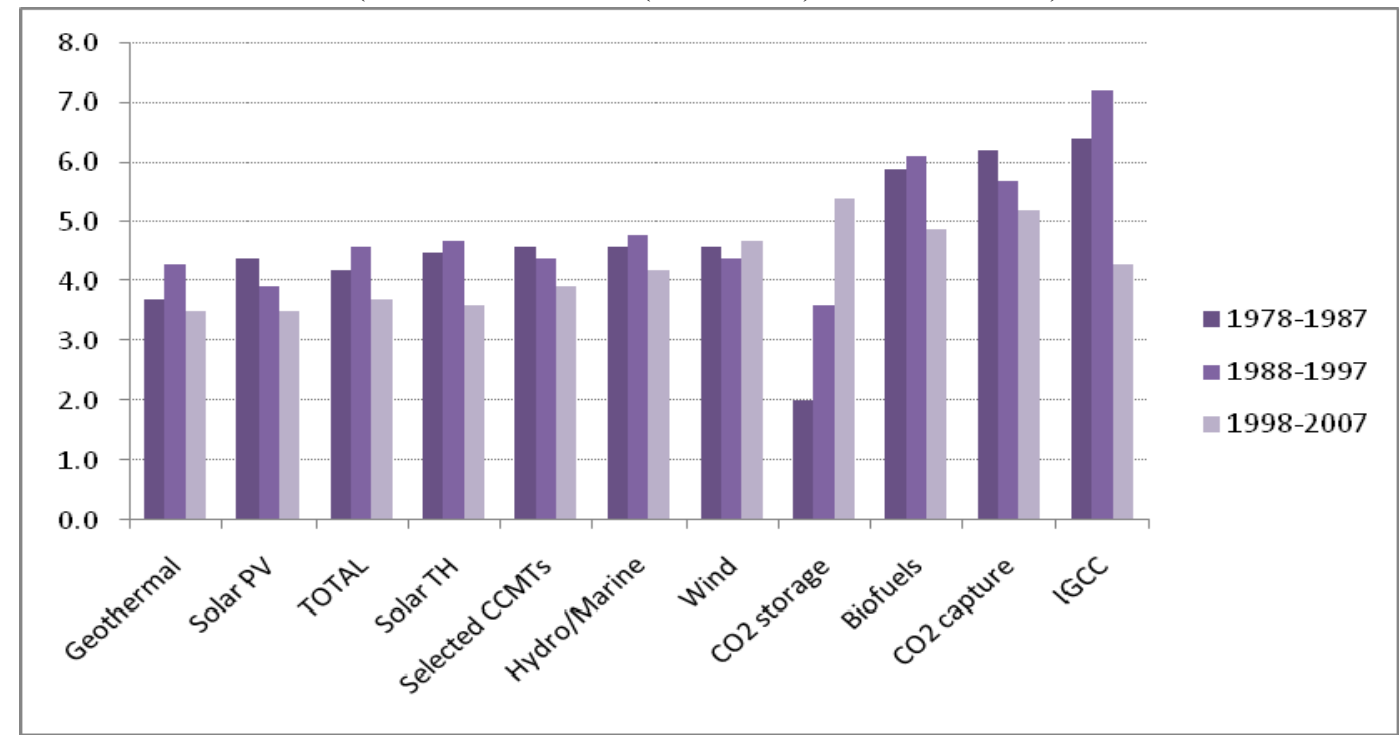

While aggregate trends are interesting, patent documentation also allows us to look at bilateral transfers between pairs of countries. ${ }^{18}$ Table 6 presents data on the main source and recipient countries for CCMT technology transfers during the period of 1988-2007. As can be seen the most important bilateral relationships are between Annex 1 countries.

Table 6. Major bilateral transfer relations in CCMT (1988-2007)

(Count of duplicate patent applications between pairs of priority and duplicate offices)

\begin{tabular}{l|rrrrrrrrrrrrrrrrr}
\hline & US & EP & JP & DE & AU & CN & CA & KR & AT & ES & GB & TW & BR & NO & FR & DK & MX \\
\hline US & & 2188 & 1798 & 1146 & 1312 & 1136 & 946 & 569 & 165 & 162 & 142 & 344 & 235 & 91 & 48 & 90 & 163 \\
JP & 4633 & 1533 & & 1161 & 561 & 1338 & 213 & 883 & 65 & 59 & 72 & 536 & 36 & 42 & 65 & 28 & 14 \\
DE & 1252 & 2501 & 751 & 850 & 610 & 471 & 344 & 186 & 406 & 310 & 35 & 49 & 192 & 136 & 62 & 160 & 75 \\
GB & 463 & 485 & 263 & 260 & 334 & 142 & 149 & 60 & 78 & 65 & 742 & 20 & 39 & 43 & 7 & 32 & 19 \\
FR & 393 & 521 & 255 & 314 & 188 & 116 & 175 & 27 & 94 & 100 & 13 & 10 & 37 & 35 & 414 & 26 & 21 \\
KR & 1008 & 140 & 484 & 95 & 37 & 348 & 9 & 168 & 2 & 3 & 22 & 41 & 2 & 4 & 8 & 1 & 2 \\
EP & 327 & & 157 & 243 & 129 & 146 & 73 & 47 & 137 & 75 & 6 & 5 & 17 & 18 & 2 & 66 & 8 \\
SE & 84 & 106 & 47 & 82 & 103 & 28 & 42 & 10 & 31 & 24 & & 6 & 13 & 23 & 1 & 16 & 3 \\
NL & 77 & 167 & 53 & 110 & 121 & 28 & 33 & 7 & 37 & 34 & 4 & 2 & 15 & 13 & 1 & 25 & 6 \\
AU & 105 & 86 & 52 & 25 & 346 & 46 & 39 & 9 & 10 & 10 & 3 & 2 & 15 & 5 & & 2 & 11 \\
NO & 74 & 98 & 41 & 53 & 104 & 41 & 53 & 14 & 30 & 20 & 7 & & 11 & 179 & 14 & 1 \\
IT & 88 & 207 & 32 & 78 & 46 & 32 & 28 & 6 & 27 & 23 & 1 & 6 & 13 & 9 & 1 & 8 & 2 \\
DK & 80 & 114 & 27 & 74 & 93 & 65 & 52 & & 35 & 23 & 1 & & 6 & 16 & 107 & 6 \\
ES & 60 & 115 & 18 & 47 & 47 & 37 & 16 & 1 & 24 & 179 & 2 & & 11 & 4 & 2 & 8 & 10 \\
AT & 38 & 102 & 24 & 54 & 38 & 21 & 28 & 11 & 91 & 19 & & & 14 & 12 & 1 & 5 & 8 \\
FI & 46 & 71 & 29 & 49 & 51 & 16 & 31 & 4 & 20 & 12 & 1 & & 7 & 10 & 1 & 9 & 1 \\
CA & 97 & 45 & 24 & 30 & 53 & 17 & 104 & 5 & 9 & 7 & 5 & & 8 & 6 & 2 & 2 & 7 \\
CN & 60 & 35 & 11 & 8 & 46 & 158 & 8 & 5 & 2 & 1 & & & 2 & & 2 & 1 \\
IL & 48 & 32 & 13 & 23 & 47 & 10 & 7 & 3 & 9 & 9 & 3 & & 9 & 2 & 1 \\
\hline
\end{tabular}

${ }^{18}$ See OECD (2009b). 
Given the relative importance of developed economies in CCMT innovation, there are particular benefits from encouraging flows of climate change mitigation inventions originating in Annex 1 countries to nonAnnex 1 countries. Indeed, the Clean Development Mechanism within the Kyoto Protocol has sought to encourage diffusion of technologies (amongst other aims) to non-Annex 1 countries in an effort to accelerate efforts to mitigate climate change. Tables 7-8 below provide data on the extent of flows from Annex 1 to non-Annex 1 countries with respect solar PV and solar thermal technologies. In addition to China, Korea and Taiwan, the biggest recipient countries include Israel, Brazil, Mexico, South Africa and Morocco.

Table 7. Transfer of solar PV to non-Annex I (1988-2007)

(Count of duplicate patent applications between pairs of priority and duplicate offices)

\begin{tabular}{l|rrrrrrrrrrrrr}
\hline & CN & KR & TW & BR & SG & MX & IL & HK & ZA & AR & ID & IN & MA \\
\hline JP & 1067 & 788 & 503 & 7 & 13 & 3 & 1 & 9 & 1 & & 3 & 1 & \\
US & 663 & 409 & 318 & 47 & 74 & 46 & 46 & 20 & 11 & 15 & 1 & 2 & \\
DE & 185 & 104 & 46 & 19 & 3 & 14 & 10 & 11 & 9 & & & 1 & \\
GB & 57 & 41 & 17 & 6 & & 4 & 4 & 6 & 8 & & & 2 & \\
FR & 35 & 10 & 3 & 8 & 1 & 7 & 5 & & 7 & & & & 2 \\
AU & 18 & 5 & 1 & 3 & & 3 & 3 & & 5 & & 3 & & 1 \\
NL & 10 & 3 & 2 & 4 & 1 & 2 & 1 & 1 & 1 & & & & \\
SE & 6 & 3 & 3 & & & & & 1 & & & & & \\
IT & 5 & 1 & 2 & & & & 1 & 2 & & & & & \\
NO & 9 & & & 2 & & & & 4 & & & & & \\
ES & 5 & & & & & 3 & & & & & & \\
AT & 7 & 3 & & & & & & & & 1 & & & \\
CH & 4 & 1 & 1 & & & & & & & & & \\
\hline
\end{tabular}

Note: While TW and HK were not parties to the UNFCCC Convention, are included in the table due to the important volume of transfer. 
Table 8. Transfer of solar TH to non-Annex I (1988-2007)

(Count of duplicate patent applications between pairs of priority and duplicate offices)

\begin{tabular}{|c|c|c|c|c|c|c|c|c|c|c|c|c|c|c|c|}
\hline & $\mathrm{CN}$ & $\mathrm{IL}$ & BR & $\mathrm{MX}$ & $\mathrm{KR}$ & ZA & $\mathrm{HK}$ & MA & AR & EG & $\mathrm{DZ}$ & TW & ID & SG & IN \\
\hline DE & 46 & 28 & 16 & 11 & 8 & 11 & 2 & 4 & 1 & 3 & 1 & & & 1 & 3 \\
\hline US & 58 & 33 & 23 & 25 & 18 & 7 & 8 & 1 & 4 & 1 & & 3 & 1 & 1 & \\
\hline $\mathrm{JP}$ & 49 & 1 & 3 & 5 & 16 & & 1 & & & & & 2 & 1 & 1 & \\
\hline FR & 8 & 7 & 6 & 7 & 1 & 4 & & 2 & & & 1 & & & & \\
\hline$A U$ & 19 & 2 & 7 & 4 & 3 & 8 & 1 & 1 & & 1 & 1 & & 1 & & 1 \\
\hline GB & 9 & 1 & 1 & 3 & & 4 & & & & & & & & & \\
\hline NL & 7 & 3 & 4 & 4 & 2 & 1 & 2 & 2 & & & & & & & \\
\hline AT & 4 & 2 & 3 & 2 & 2 & 1 & 1 & 1 & & & 1 & & & 1 & \\
\hline ES & 9 & 3 & 4 & 2 & & 1 & & 1 & 1 & & & & & & \\
\hline IT & 4 & 2 & 1 & 1 & 2 & 1 & 2 & & 2 & & & & & & \\
\hline SE & 6 & & & & 1 & & & & & & & & & & \\
\hline NO & 2 & & & & & & & & & & & & & & \\
\hline CA & 3 & 1 & 1 & 3 & 1 & 1 & 1 & 1 & & & & & & & \\
\hline $\mathrm{HU}$ & 3 & 1 & 5 & 1 & 1 & 1 & & & & & & & 1 & & \\
\hline $\mathrm{CH}$ & 3 & & & 1 & & & & & & & & & & & \\
\hline GR & 3 & & & & & 1 & & & & & & & & & \\
\hline
\end{tabular}

However, there are large differences in the volume of patent applications deposited at different patent offices. Data presented in Appendix C lists patent offices with the highest proportion of CCMT filings. Interestingly, among the largest offices those located in Asia rank highest in recent years, a trend most likely driven by patenting in solar PV.

In the context of climate change mitigation, transfer of CCMTs to non-Annex I countries is of particular importance. The largest flows of solar PV, wind power, biofuels and $\mathrm{CO}_{2}$ capture are represented graphically in Figure 24. In this case European inventors are shown as one country. ${ }^{19}$ The sizes of arrows are comparable within and between the figures; with the exception of solar PV where the flows are approximately three orders of magnitude greater than in the remaining three cases.

China dominates as the most important recipient country, with Korea, Brazil and South Africa also important in all areas. However, in some specific areas other countries emerge as important recipients e.g. Morocco for wind power and Indonesia for carbon capture. The relative importance of the source countries is also very different in the different fields. While the US dominates PV, Europe is most important for wind power and biofuels. While Japan is a dominant innovator in all fields, there is less evidence of transfer.

\footnotetext{
${ }^{19}$ This includes countries of the European Economic Area (i.e. EU27 + Norway, Iceland, Switzerland, Liechtenstein).
} 
ENV/WKP(2010)16

Figure 24. International Transfer of Selected CCMT Technologies, from Annex I to non-Annex I countries (1988-2007)

a. Solar PV

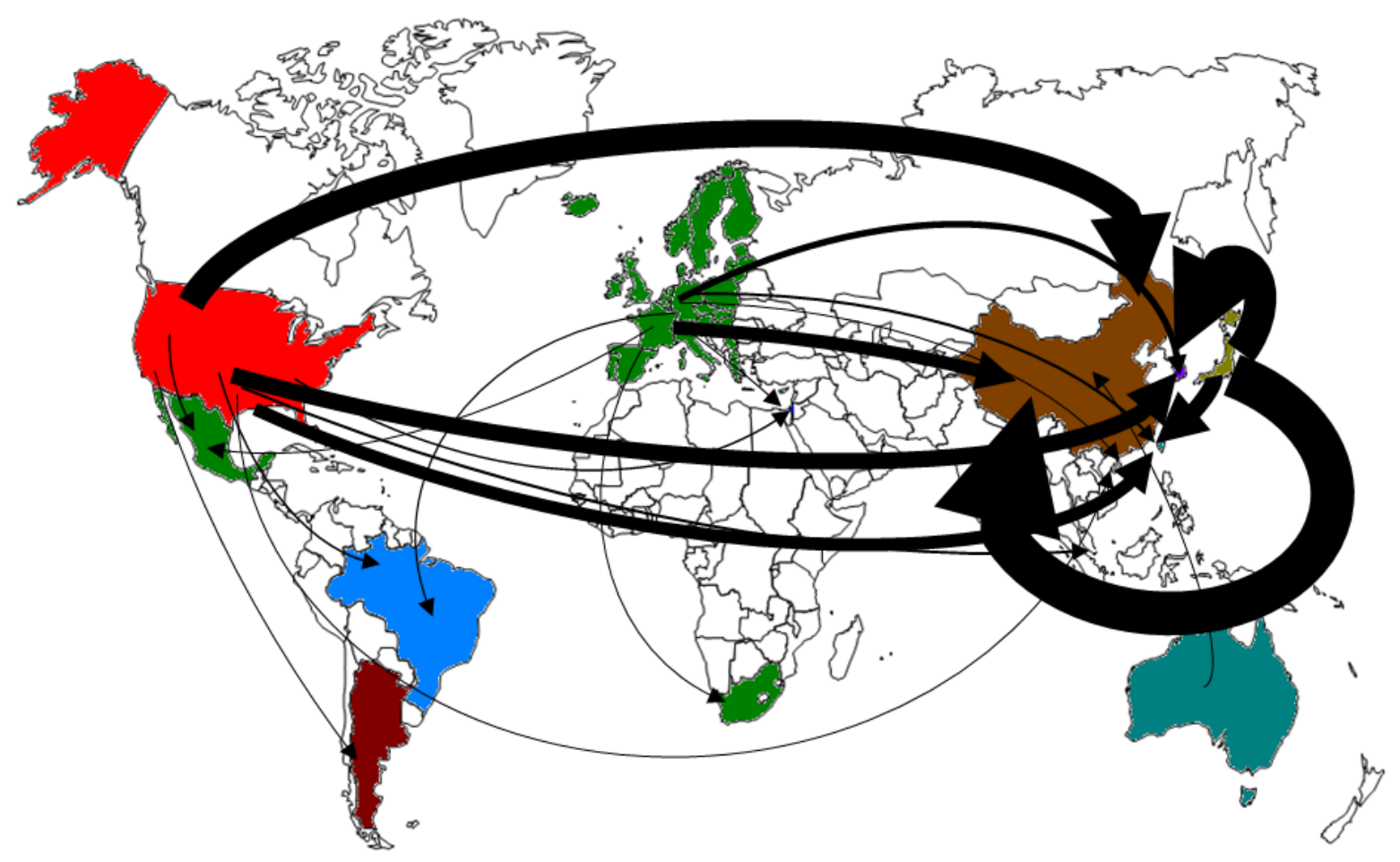

b. Wind power

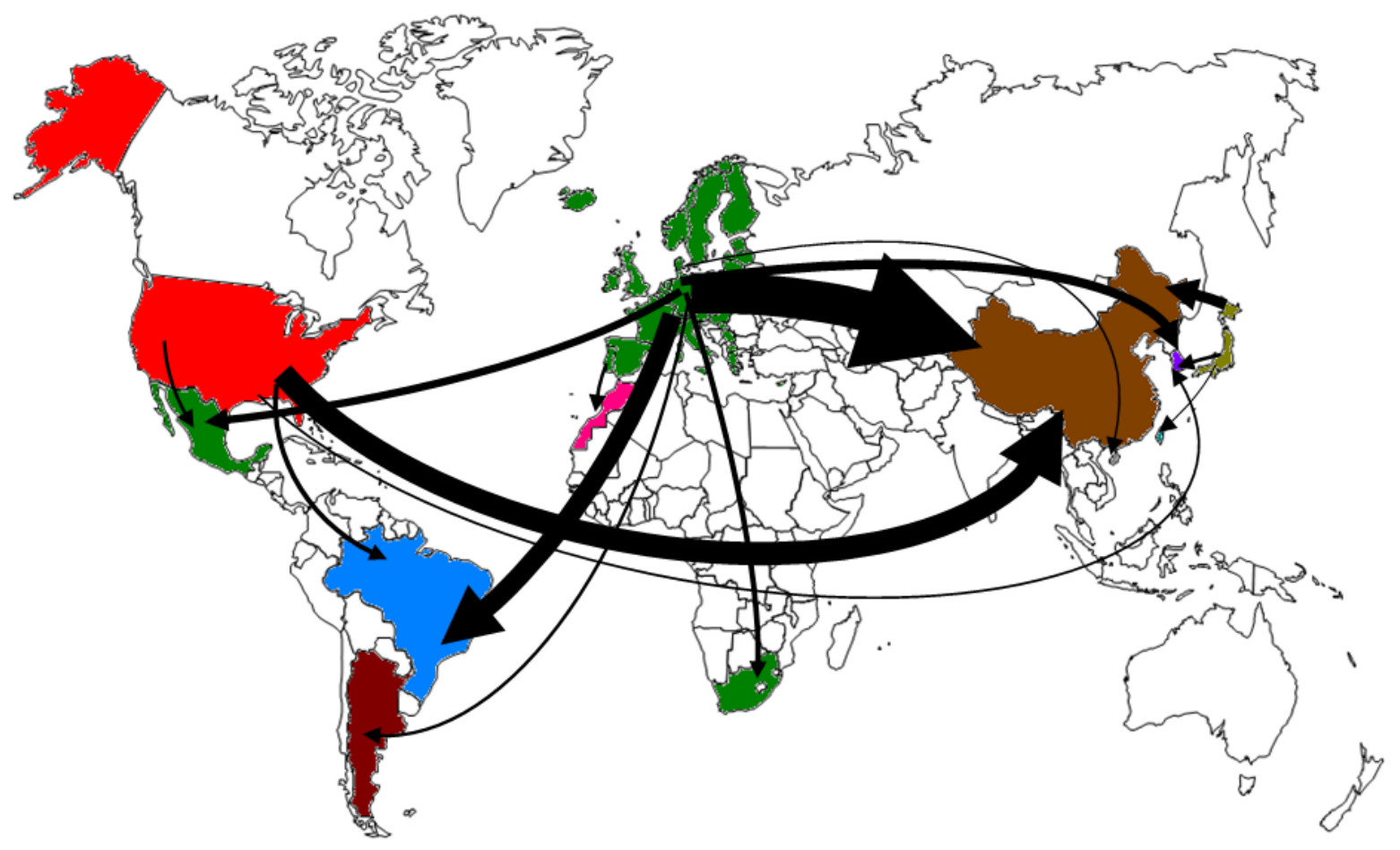


c. Biofuels

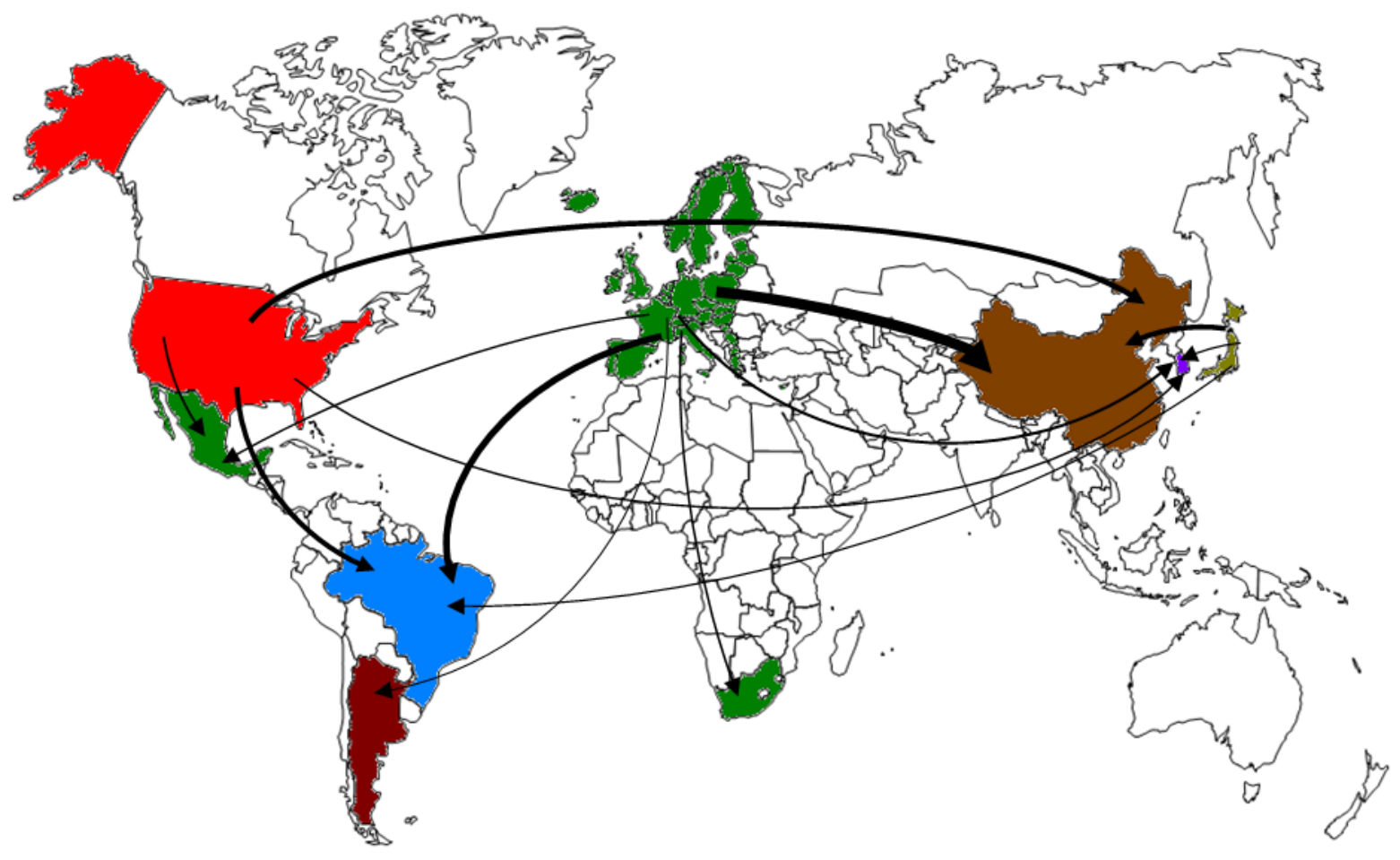

d. $\mathrm{CO}_{2}$ capture

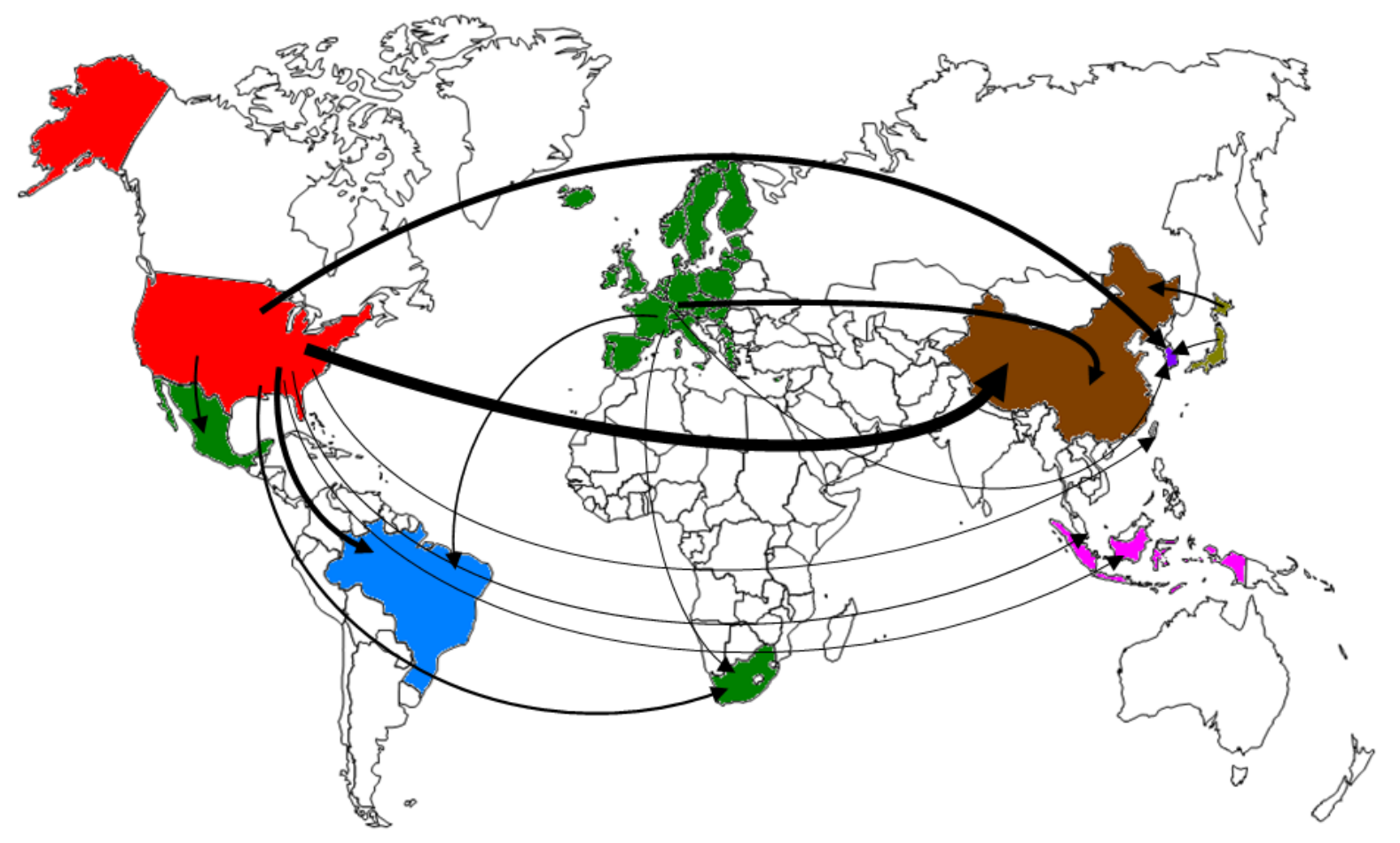

However, it should be recognised that large bilateral transfers in a specific technology may simply be associated with large volume of technology transfers in general. Therefore, it is important to control for 
these effects econometrically. In regression models estimated for wind power, a variable representing technology transfers overall is included. This allows isolating the effect of the CDM (and other factors).

The results suggest that the effect of CDM is small compared to other factors. For example, domestic innovation capacity in host countries plays a much greater role than CDM involvement in encouraging transfer. Moreover, the benefits of CDM in encouraging transfer appear to diminish with the cumulative stock of projects in place. While further research is required, these results may be attributable to the important role that initial projects play in helping develop domestic innovation capacity, and in facilitating access to technologies available on the world market (Haščič and Johnstone 2011).

\section{Internationalisation of Research in the CCMT sector}

As noted above, climate change is a global problem, requiring international co-operation - both at the level of policy and at the level of innovation itself. Moreover, some of the most important channels of 'transfer' are not embedded in technologies, but in knowledge itself. In this section we look at the extent of internationalisation of research which is taking place in CCMT technologies.

At the crudest level it is interesting to examine the propensity for inventors to patent abroad. Distinguishing by field of technology, the figure below presents this data for the last thirty years. There has been a general increase, since the fall in recent years is certainly due to the lags associated with duplicate applications.

Figure 25. Propensity to Patent Abroad

$(\%$ share of $\mathrm{CP} /(\mathrm{CP}+\mathrm{SING}))$

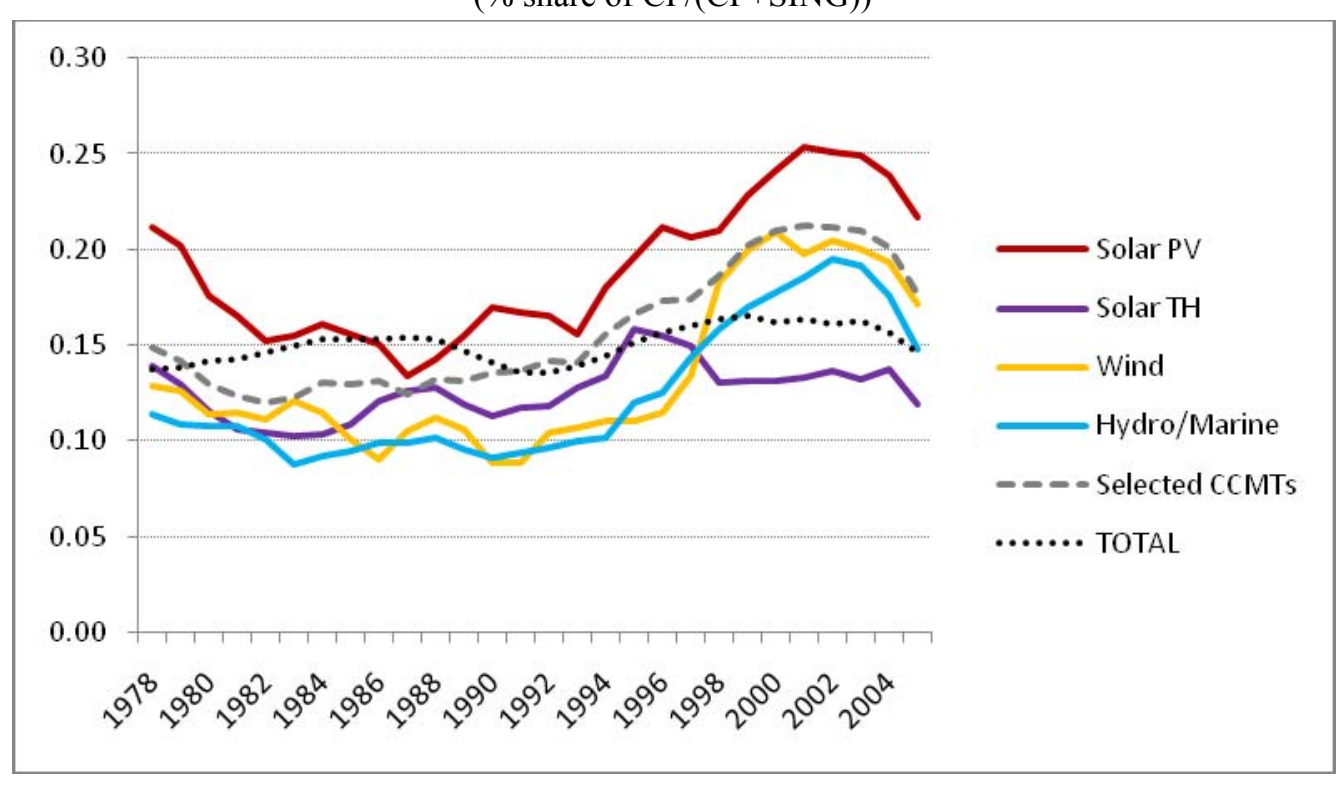

However, it is more illuminating to examine the extent of direct research collaboration. To this end Table 9 shows the rank of countries in different fields in terms of the likelihood of the technologies having been invented by researchers from more than one country. While Japan is the dominant inventor in many fields, co-operation is much less evident. Conversely, the US is the biggest 'co-inventor' in all but two fields.

Table 9. International Research Collaboration in CCMT (co-invention)

(Top five co-inventors, measured as number of inventions that involve co-invention, 1978-2007)

1. $2 . \quad 3.4$. 5 .


ENV/WKP(2010)16

\begin{tabular}{llllll}
\hline Solar PV & US & DE & JP & GB & CN \\
Solar TH & DE & US & CH & ES & FR \\
Wind & US & DE & DK & GB & NL \\
Geothermal & GB & US & AT & CN & NO \\
Hydro/Marine & US & DE & CA & GB & CH \\
Biofuels & US & DK & DE & NL & GB \\
$\mathrm{CO}_{2}$ Capture & US & GB & DE & CA & NL \\
$\mathrm{CO}_{2}$ Storage & US & NL & CA & GB & FR \\
IGCC & US & GB & NL & DE & FI \\
Selected & & & & & \\
CCMTs & US & DE & GB & JP & NL
\end{tabular}

Table 10. International Research Collaboration in CCMT

(Number of inventions (priorities) that involve co-invention between a pair of countries, 1978-2007)

\begin{tabular}{|c|c|c|c|c|c|c|c|c|c|c|c|c|c|c|c|c|c|c|c|c|}
\hline & $\mathrm{DE}$ & GB & $\mathrm{CN}$ & CA & $\mathrm{CH}$ & $\mathrm{JP}$ & $\mathrm{BE}$ & FR & AT & IN & $\mathrm{NL}$ & DK & $\mathrm{RU}$ & $\mathrm{AU}$ & IT & KR & TW & ES & SE & Other \\
\hline US & 309 & 181 & 132 & 143 & 43 & 175 & 40 & 62 & 33 & 98 & 107 & 53 & 44 & 27 & 35 & 54 & 52 & 27 & 9 & 186 \\
\hline $\mathrm{DE}$ & & & 23 & 11 & 102 & & 20 & & 51 & & & & & 17 & & & & & & \\
\hline $\mathrm{NL}$ & 47 & 48 & 1 & 2 & 3 & 5 & 32 & 7 & 1 & 1 & & 3 & & 5 & 5 & & & 14 & & \\
\hline GB & 58 & & 22 & 13 & 7 & & 4 & 17 & 4 & & & 29 & & 6 & & & & 10 & & \\
\hline JP & 46 & 38 & 31 & 6 & 13 & & 1 & 4 & & 3 & & 11 & & 6 & 1 & & & & & \\
\hline FR & 44 & & 3 & 17 & 26 & & 24 & & 6 & & & 1 & & 1 & & & & 3 & & \\
\hline IT & 26 & 13 & 1 & 4 & 14 & & 4 & 11 & 4 & 2 & & 1 & & & & & & 1 & & \\
\hline $\mathrm{KR}$ & 22 & 6 & 9 & 6 & & 21 & & 7 & & 5 & & & & & 2 & & & & & \\
\hline DK & 35 & & 18 & & 4 & & 7 & & & & & & & 2 & & & & & & \\
\hline TW & 6 & 3 & 44 & & & 5 & 3 & & & 2 & & & & & & 2 & & & & \\
\hline IN & 13 & 16 & 11 & 7 & 1 & & 2 & 6 & 1 & & & & & 1 & & & & & & \\
\hline SE & 13 & 2 & 1 & 5 & 12 & & 1 & 6 & 2 & 1 & 1 & 3 & 1 & & 8 & & & & & \\
\hline RU & 12 & 15 & 2 & 2 & 2 & 1 & & 1 & & 2 & 2 & 1 & & 2 & 1 & 6 & & & & \\
\hline ES & 16 & & & 1 & 5 & & 6 & & 2 & & & 11 & & & & & & & & \\
\hline $\mathrm{CH}$ & & & & 4 & & & 6 & & 11 & & & & & 12 & & & & & & \\
\hline $\mathrm{CN}$ & & & & 7 & 4 & & 4 & & 4 & & & & & 5 & & & & & & \\
\hline$C A$ & & & & & & & 8 & & 1 & & & & & 1 & & & & & & \\
\hline Other & 90 & 82 & 27 & 40 & 14 & 26 & 21 & 26 & 12 & 23 & 13 & 2 & 55 & 11 & 20 & 10 & 13 & 2 & 21 & 74 \\
\hline
\end{tabular}

Overall, $4.3 \%$ of all the selected CCMT inventions involve inventors from more than one country. In terms of individual CCMT fields, the rate of co-invention is highest for $\mathrm{CO}_{2}$ storage $(15.2 \%)$ and lowest for hydro/marine, geothermal and solar thermal (2.6-2.1\%). (Figure 26) 
Figure 26. CCMT fields by rate of co-invention

(\% share of inventions that involve co-invention, 1978-2007)

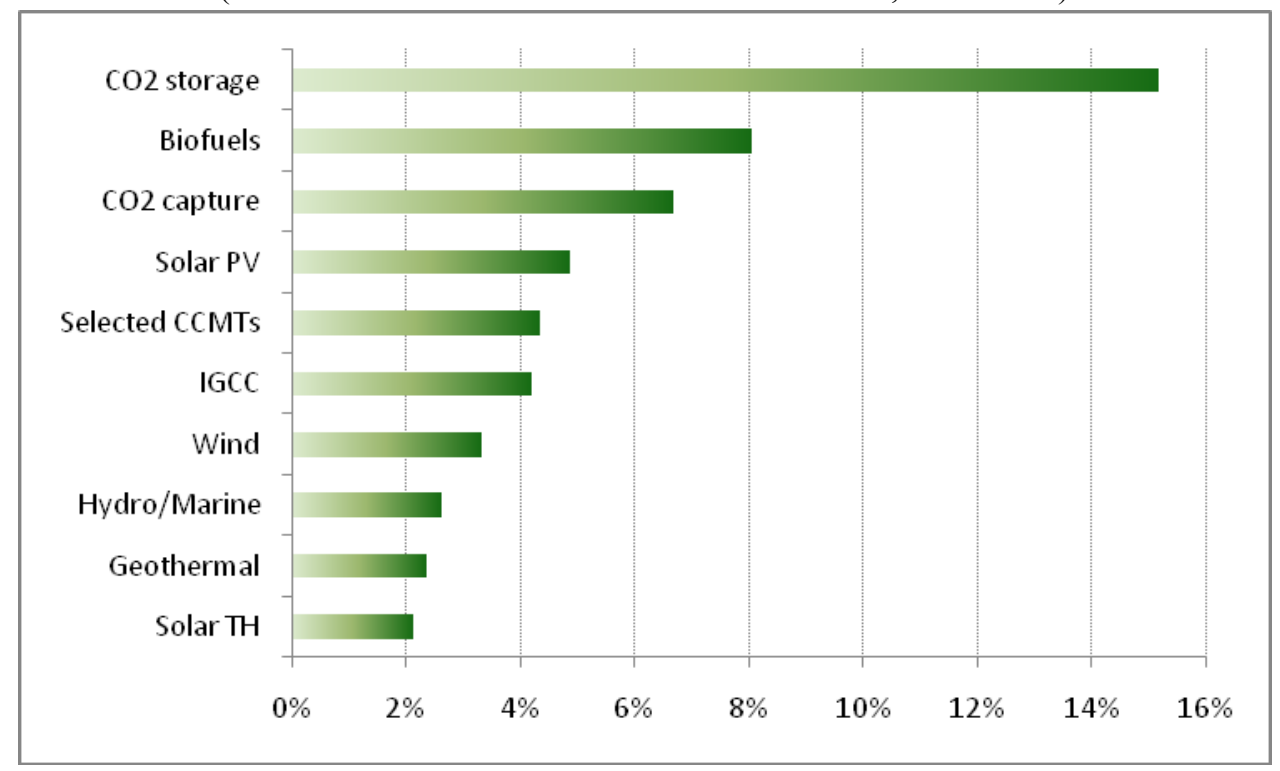

Note: The proportions are relative to the stock of inventions with known inventor countries. Inventions with missing information on country of the inventor(s) are not considered here.

Focusing on solar PV, solar thermal, wind, and biofuels, the maps below show the important coinvention relationships graphically. In all areas, the US and Europe have a high degree of co-operation. Other interesting bilateral relationships include Belarus and Russia (solar PV and thermal), South AfricaEurope (biofuels and wind), India-US (solar PV, wind), China-US (solar PV). In addition, it is interesting to note that there is little co-operation with China in terms of wind power, despite its importance in the field. 
ENV/WKP(2010)16

Figure 27. International Research Collaboration in Selected CCMT Technologies (1988-2007) a. Solar photovoltaics

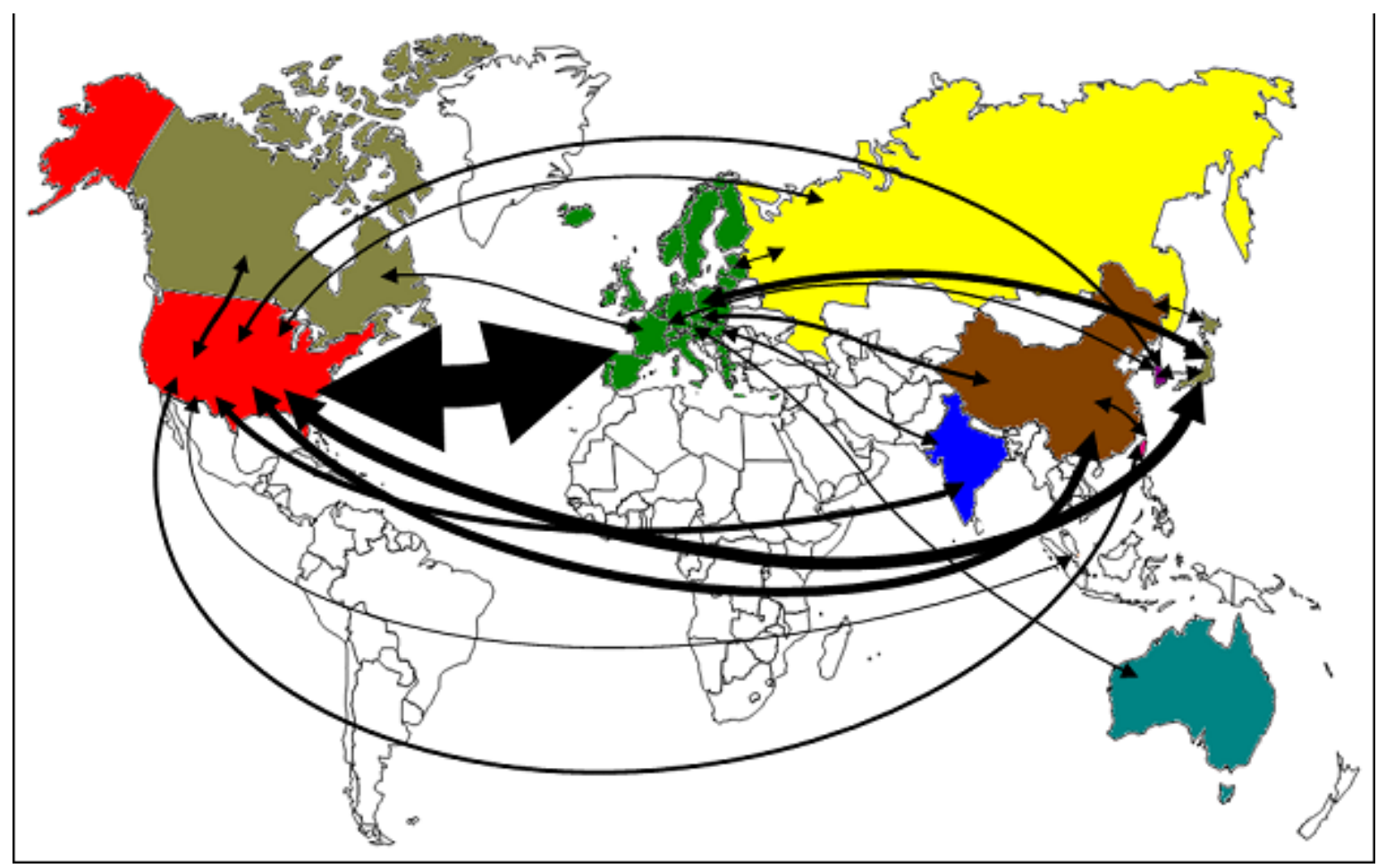

b. Solar thermal energy

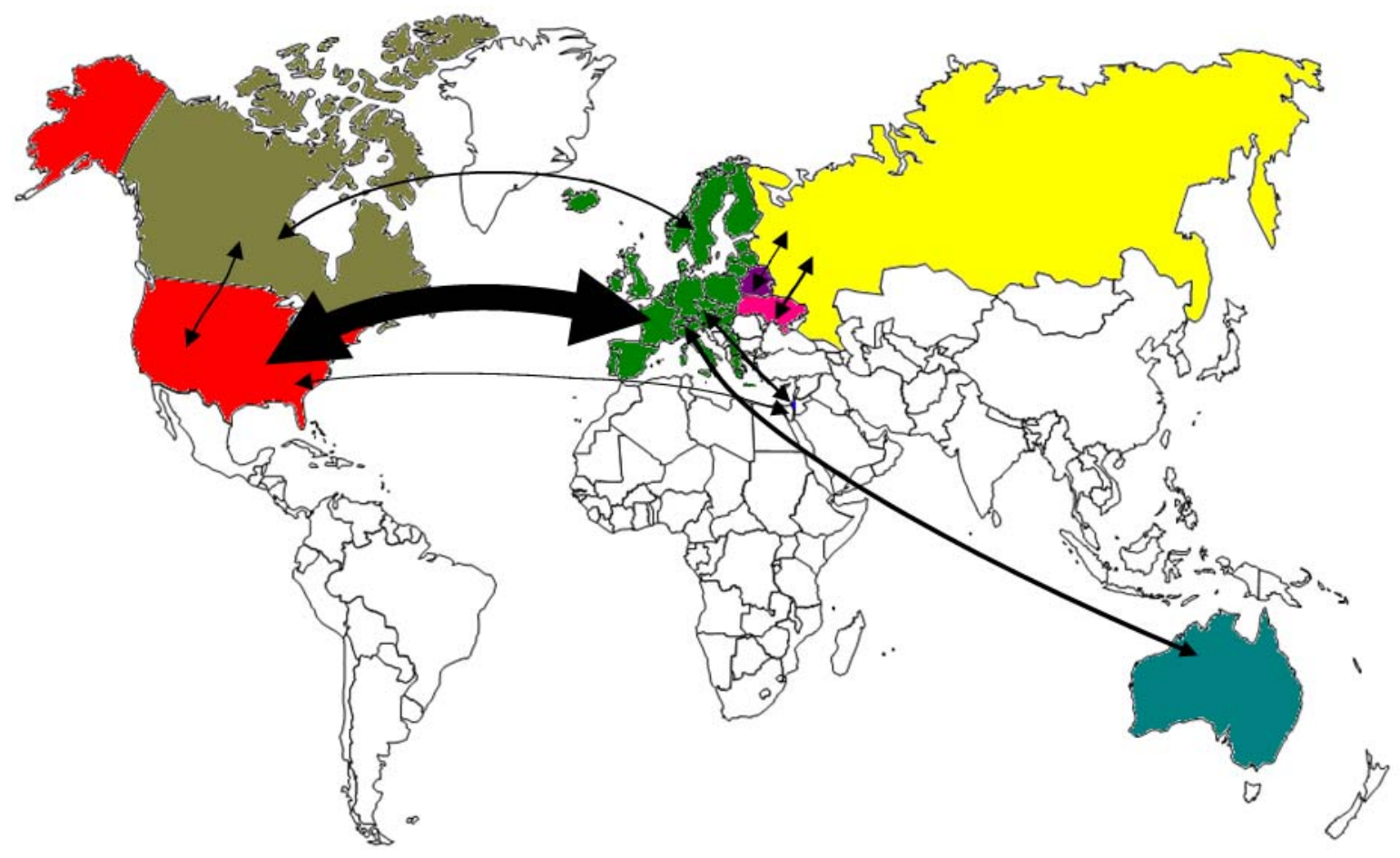


ENV/WKP(2010)16

c. Wind power

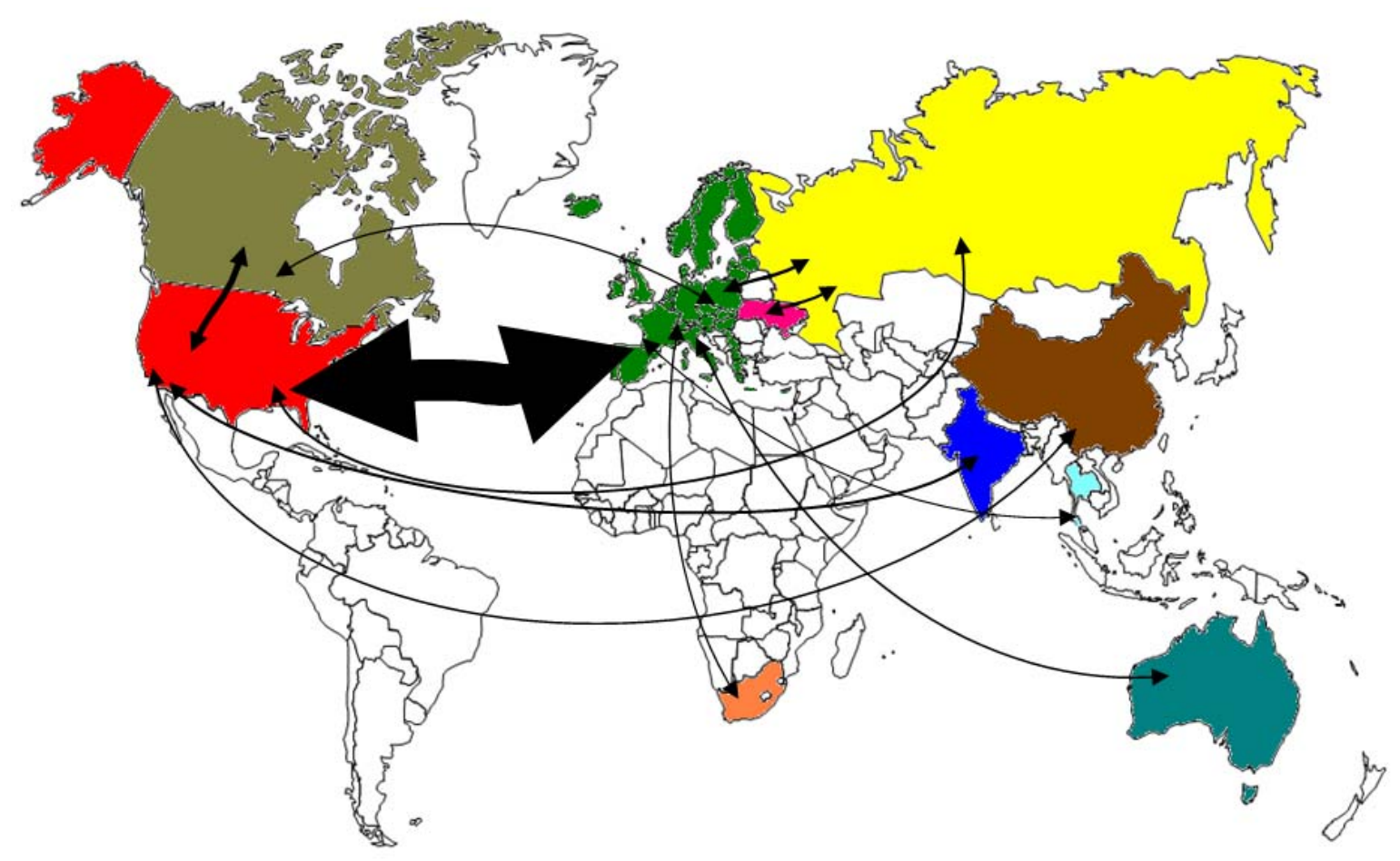

d. Biofuels

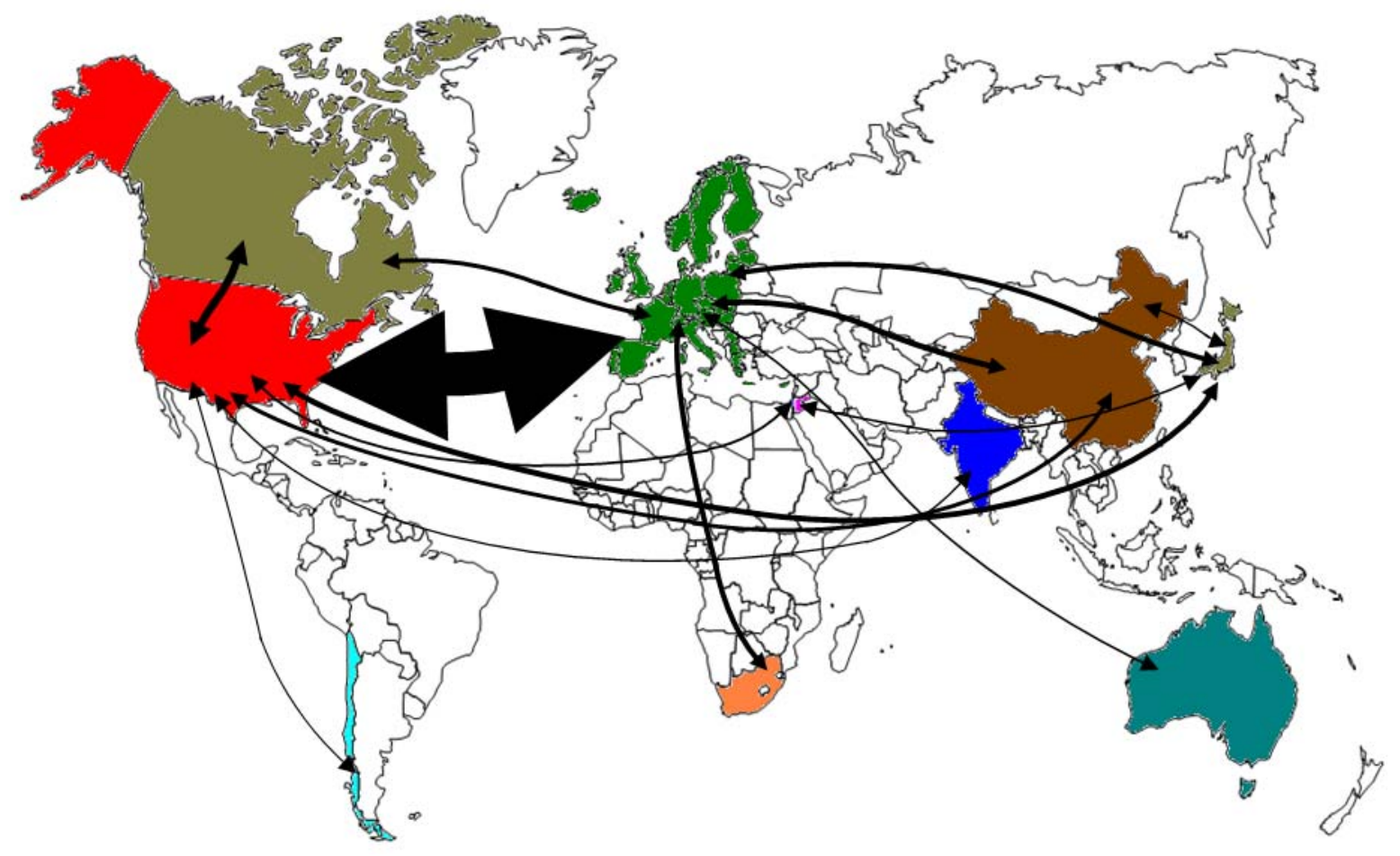




\section{ENV/WKP(2010)16}

\section{Conclusions}

This paper has provided evidence on the generation and diffusion of selected climate change mitigation technologies (CCMTs) and their respective links to key policies. The evidence presented indicates that the rate of innovation has accelerated in many CCMTs, coinciding approximately with the passage of the Kyoto Protocol. This is particularly true of those technologies that were closest to being competitive - i.e. wind power, some solar power, biofuels, geothermal and hydro. Patent activity for other technologies (i.e. CCS) showed falls, even in comparison with the rate of patenting in general and for other energy technologies.

Empirical analysis indicates that the most important determinant of innovation in the area of renewable energy technologies is general innovative capacity. A country with a high rate of innovation in general, will be innovative with respect to CCMTs. However, public policy makes a difference. Public R\&D expenditures on renewable energies induces innovation, as do targeted measures such as renewable energy certificates and feed-in tariffs. However, the effects of different measures vary by type of renewable.

With respect to technology diffusion and transfer, there is evidence of significant CCMT equipment and knowledge flows across countries. While much of the technology transfer and international research co-operation is amongst Annex 1 countries, there are non-Annex 1 countries that have become significant trade and research partners. The international diffusion of environmental and CCMTs and knowledge is key to addressing global environmental problems such as climate change.

This is particularly important since environmental technologies are currently developed, for the most part, in OECD countries, and they are not being diffused in the world economy at sufficient speed and scale. Moreover, certain technologies that are specific to the needs of developing countries are not being developed at all, because the developing countries lack the innovation capacity to do so, while the developed countries lack incentives to develop such 'neglected' technologies in the first place. This is similar in nature to the problems faced by many medicines for which demand is primarily located in developing countries with limited innovative capacity (e.g., tropical diseases).

The introduction of environmental and innovation policies by developing country governments is a pre-requisite for the development and diffusion of such technologies. However, OECD country governments themselves can also play an active role. In particular, OECD countries would need to adopt policies to provide incentives for private inventors located within their borders to develop such technologies, ideally in collaboration with innovators in developing countries. Both national measures and coordinated international agreements can play an important role in this regard.

Further work at the OECD will focus on the role of market factors, national policies and international mechanisms on the international diffusion of climate change mitigation technologies and knowledge. Particular attention will be paid to the development and adoption of technologies for which demand in nonAnnex 1 countries is likely to be significant. 


\section{REFERENCES}

Brunnermeier, S. B. and M. A. Cohen (2003), "Determinants of environmental innovation in US manufacturing industries" Journal of Environmental Economics and Management, Vol. 45, pp. 278-293.

Crabb, J.M. and D.K.N. Johnson (2007), "Fueling the Innovation Process: Oil Prices and Induced Innovation in Automotive Energy-Efficient Technology", Working Paper, Colorado Department of Economics and Business, May 2007.

de Coninck, H.C., Haake, F., van der Linden, N.H. (2007), "Technology Transfer in the Clean Development Mechanism", ECN Working Paper.

Dechezleprêtre, A., Glachant, M., Haščič, I., Johnstone, N. and Y. Ménière (2011), "Invention and Transfer of Climate Change Mitigation Technologies: A Global Analysis", Review of Environmental Economics and Policy (forthcoming 2011).

Dechezleprêtre, A., M. Glachant and Y. Ménière (2009), "Technology Transfer by CDM Projects: A Comparison of Brazil, China, India and Mexico", Energy Policy, Vol. 37, pp. 703-711.

Dechezleprêtre, A., Glachant, M., and Y. Ménière (2008), "The Clean Development Mechanism and the International Diffusion of Technologies: An Empirical Study”, Energy Policy, Vol. 36, pp. 12731283.

Dernis, H., Guellec D. and B. van Pottelsberghe (2001), "Using Patent Counts for Cross-Country Comparisons of Technology Output", STI Review 27, OECD, Paris, France.

(http://www.oecd.org/LongAbstract/0,3425,en_2649_33703_21682516_1_1_1_1,00.html).

Eaton, J. and S. Kortum (1999), "International Technology Diffusion: Theory and Measurement", International Economic Review, Vol. 40, No. 3, pp. 537-570.

Eaton, J., and S. Kortum (1996), "Trade in ideas Patenting and productivity in the OECD", Journal of International Economics, Vol. 40(3-4), pp. 251-278.

EPO (European Patent Office) (2009), Worldwide Patent Statistical Database (PATSTAT), April 2009 version.

Fisher-Vanden, K., G. Jefferson, J. Ma, and J. Xu (2006), “Technology development and energy productivity in China", Energy Economics 28(5/6):690-705.

Griliches Z. (1990), "Patent Statistics as Economic Indicators: A Survey", Journal of Economic Literature, Vol. 28, No. 4, p. 1661-1707.

Guellec, D. and B. van Pottelsberghe de la Potterie (2000). "Applications, Grants and the Value of a Patent", Economics Letters, Vol. 69, pp. 109-114.

Haites, E., Duan, M., and S. Seres (2006), "Technology Transfer by CDM Projects", Report for the BASIC Project (http://www.basic-project.net).

Harhoff, D., Scherer, F.M. and K. Vopel (2003), "Citations, family size, opposition and the value of patent rights", Research Policy 32: 1343-63.

Haščič, I. and N. Johnstone (2011), "The Clean Development Mechanism and International Technology Transfer: Empirical Evidence on Wind Power," Climate Policy (forthcoming).

Haščič, I., Johnstone, N. and M. Kalamova (2009), "Environmental Policy Flexibility, Search and Innovation", Czech Journal of Economics and Finance, Vol. 59, Issue 5.

Helfgott, S. (1993), "Patent filing costs around the world", Journal of the Patent and Trademark Office Society, July, pp. 567-580. 
Jaffe, A. B. and K. Palmer (1997), "Environmental Regulation and Innovation: A Panel Data Study", The Review of Economics and Statistics, Vol. 79, No. 4, pp. 610-619.

Johnstone, N. and I. Haščič (2011), "Environmental Policy Design and the Fragmentation of International Markets for Innovation”, In Ghosal, V. (ed.) Reforming Rules and Regulations, Chapter 4. Cambridge, Mass: MIT Press.

Johnstone, N. and I. Haščič (2009), "Environmental Policy Framework Conditions, Innovation and Technology Transfer". OECD Environment Directorate, General Distribution Document ENV/EPOC/WPNEP(2009)2/FINAL (http://www.oecd.org/environment/innovation).

Johnstone, N., I. Haščič and D. Popp (2010), "Renewable Energy Policies and Technological Innovation: Evidence Based on Patent Counts", Environmental and Resource Economics 45(1):133-55.

Lanjouw, J.O. and A. Mody (1996), "Innovation and the International Diffusion of Environmentally Responsive Technology", Research Policy, Vol. 25, pp. 549-571.

Lee, B., Ilian Iliev, and Felix Preston (2009), "Who Owns Our Low Carbon Future? Intellectual Property and Energy Technologies", Chatham House Report.

OECD (2008). Environmental Policy, Technological Innovation and Patents. Paris: OECD.

OECD (2009a). OECD Patent Statistics Manual. Paris: OECD.

OECD (2009b). "Indicators of Innovation and Transfer in Environmentally Sound Technologies: Methodological Issues". OECD Environment Directorate, General Distribution Document ENV/EPOC/WPNEP(2009)1/FINAL (http://www.oecd.org/environment/innovation).

OECD (2009c). "Energy and Climate Change Policy, Innovation and Technology Transfer", OECD Environment Directorate report ENV/EPOC/WPNEP(2009)3, revised version forthcoming (http://www.oecd.org/environment/innovation).

OECD (2009d). The Economics of Climate Change Mitigation. Paris: OECD.

Popp, David (2006), "International Innovation and Diffusion of Air Pollution Control Technologies: The Effects of NOX and SO2 Regulation in the U.S., Japan, and Germany", Journal of Environmental Economics and Management, Vol. 51, Issue 1, pp. 46-71.

Popp, David (2003), "Pollution Control Innovations and the Clean Air Act of 1990", Journal of Policy Analysis and Management, Vol. 22, No. 4, pp. 641-660.

Popp, D., Haščič, I. and N. Medhi (2010), "Technology and the Diffusion of Renewable Energy”, Energy Economics (forthcoming) (http://dx.doi.org/10.1016/j.eneco.2010.08.007).

Seres S., Haites, E. and K. Murphy (2009), "Analysis of Technology Transfer in CDM Projects: An Update", Energy Policy, Volume 37, Issue 11, November 2009, Pages 4919-4926

Taylor, Margaret R., Edward S. Rubin and David D. Hounshell (2003), "Effect of government actions on technological innovations for SO2 control", Environmental Science and Technology 37: 4527-4534.

van Pottelsberghe, B., and D. Francois (2006), The Cost Factor in Patents. CEPR Discussion Paper No. 5944, Nov. 2006. 
ENV/WKP(2010)16

APPENDIX A. LIST OF CCMT FIELDS

\begin{tabular}{|c|c|c|c|}
\hline Field & Sub-field & Notes & $\begin{array}{l}\text { Count of } \\
\text { appln_id's in } \\
\text { PATSTAT } \\
\text { (APR09) } \\
\end{array}$ \\
\hline \multirow[t]{5}{*}{ GEOTHERMAL_all } & & & 4761 \\
\hline & geo_earthcoil_he & Earth coil heat exchangers & 560 \\
\hline & geo_hdr & Hot Dry Rock systems (drilling) & 354 \\
\hline & geo_heatpump & $\begin{array}{l}\text { geothermal heat pump (for } \\
\text { buildings) }\end{array}$ & 133 \\
\hline & geo_pipes & hardware (pipes) & 1188 \\
\hline \multirow[t]{7}{*}{ HYDRO_all } & & & 45028 \\
\hline & hydro_conventional & & 15475 \\
\hline & hydro_otec & $\begin{array}{l}\text { OTEC = ocean thermal energy } \\
\text { conv. }\end{array}$ & 567 \\
\hline & hydro_owc & OWC = oscillating water column & 527 \\
\hline & hydro_salinity_gradient & & 1073 \\
\hline & hydro_stream & "stream" is mainly "river and tidal" & 4369 \\
\hline & hydro_wave & & 6491 \\
\hline \multirow[t]{7}{*}{ SOLAR_THERMAL_all } & & & 43806 \\
\hline & solar_thermal_dish & & 1435 \\
\hline & solar_thermal_fresnel & & 912 \\
\hline & solar_thermal_trough & & 2030 \\
\hline & solar_thermal_tower & & 1734 \\
\hline & solar_heat-exchange-systems & & 24465 \\
\hline & solar_mountings_and_tracking & & 6657 \\
\hline \multirow[t]{10}{*}{ SOLAR_PV_all } & & & 89675 \\
\hline & Amorph_Si_PV & & 2351 \\
\hline & cis_mater_pv & & 1602 \\
\hline & concentr_pv & & 5678 \\
\hline & DSSC_cells & & 4345 \\
\hline & II-VI_mater_PV & & 1867 \\
\hline & III-V_mater_PV & & 2771 \\
\hline & Microcryst_Si & & 179 \\
\hline & Polycryst_Si & & 506 \\
\hline & pv_roof_systems & & 4597 \\
\hline \multicolumn{2}{|c|}{ SOLAR_THERMAL_PV_HYBRID } & & 1876 \\
\hline
\end{tabular}


ENV/WKP(2010)16

\begin{tabular}{|c|c|c|c|}
\hline \multirow[t]{8}{*}{ WIND_all } & & & 33996 \\
\hline & wind_blades_and_rotors & & 9736 \\
\hline & wind_components_and_gearbox & & 11970 \\
\hline & wind_control & & 9879 \\
\hline & wind_generator_and_configuration & & 4896 \\
\hline & wind_nacelles & & 878 \\
\hline & wind_offshore_tower & & 798 \\
\hline & wind_onshore_tower & & 5672 \\
\hline \multirow[t]{9}{*}{ BIOFUELS } & & & 15403 \\
\hline & bio_CHPturbines & CHP turbines for bio-feed & 1453 \\
\hline & bio_Gasturbines & gas turbines for bio-feed & 689 \\
\hline & bio_diesel & & 2300 \\
\hline & bio_pyrolysis & & 4375 \\
\hline & bio_torrefaction & & 123 \\
\hline & bio_ethanol_cellulosic & & 1540 \\
\hline & bio_ethanol_grain & & 5816 \\
\hline & bio_alcohol-non-ferment & by other means than fermentation & 197 \\
\hline \multirow[t]{7}{*}{ CCS_capture } & & & 8069 \\
\hline & ccs_capture_absorption & CCS $=$ Carbon Capture and Storage & 2838 \\
\hline & ccs_capture_adsorption & & 2422 \\
\hline & ccs_capture_biological & & 83 \\
\hline & ccs_capture_chemical & & 2284 \\
\hline & ccs_capture_membrane_diffusion & & 985 \\
\hline & $\begin{array}{l}\text { ccs_capture_rectification } \\
\text { and_condensation }\end{array}$ & & 1342 \\
\hline CCS_storage & & & 670 \\
\hline \multirow[t]{3}{*}{ IGCC } & & & 2581 \\
\hline & igcc & $\begin{array}{l}\text { IGCC = Integrated Gasification } \\
\text { Combined Cycle }\end{array}$ & 2572 \\
\hline & igcc_with-ccs & & 28 \\
\hline
\end{tabular}

Note: The classification of CCMT fields as well as their tagging inside PATSTAT was provided by the European Patent Office (EPO). 


\section{APPENDIX B. COMPARISON OF COUNTS FOR DIFFERENT TYPES OF PATENT CLAIM}

Figure 28 shows that CPs account for a relatively small proportion of the stock of CCMT patent applications, with protection for over $60 \%$ of all CCMT inventions only being sought at a single office (SING).

\section{Figure 28. The Relative Importance of Different Patent Claims}

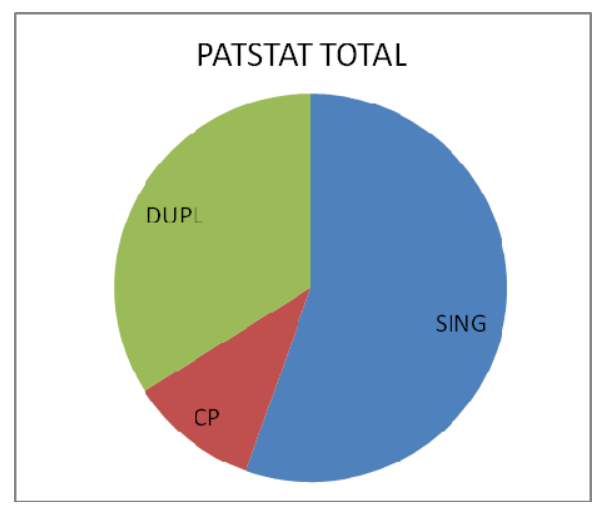

It is interesting to compare these proportions at the major intellectual property offices. The percentage of "claimed priorities' (our chosen measure), varies between $1 \%$ to $13 \%$ of all applications filed at the four major patent offices (11\% for the data included in PATSTAT overall), and represents between $2 \%$ and $20 \%$ of the stock of inventions (SING+CP) $(16 \%$ for PATSTAT overall). Therefore, in addition to allowing for the identification of high-value patents, the use of 'claimed priorities' controls for some of the biases associated with different practices at different IP offices.

Figure 29. Comparison of CCMT patent counts (1978-2007)

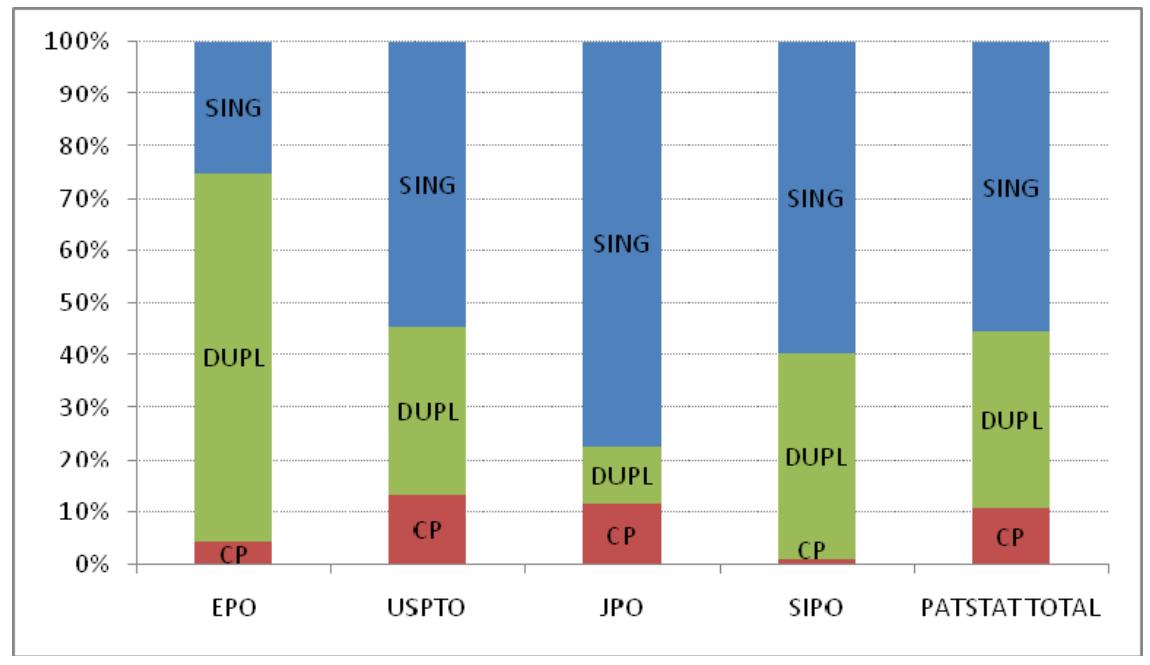




\section{APPENDIX C. SUPPLEMENTARY DATA}

Table 11. Patenting activity of inventor countries in selected CCMT fields (1988-2007)

\begin{tabular}{|c|c|c|c|c|c|c|c|c|c|c|c|c|}
\hline & $\begin{array}{c}\text { Solar } \\
\text { PV }\end{array}$ & $\begin{array}{c}\text { Solar } \\
\text { TH }\end{array}$ & Wind & Geo-thermal & $\begin{array}{l}\text { Hydro/ } \\
\text { Marine }\end{array}$ & Biofuels & $\begin{array}{c}\mathrm{CO} 2 \\
\text { Capture }\end{array}$ & $\begin{array}{c}\mathrm{CO} 2 \\
\text { Storage }\end{array}$ & IGCC & $\begin{array}{l}\text { Selected } \\
\text { CCMTs }\end{array}$ & $\begin{array}{c}\text { F\&N } \\
\text { Energy }\end{array}$ & $\begin{array}{c}\text { All_sectors } \\
\text { (TOTAL) }\end{array}$ \\
\hline US & 1303 & 172 & 320 & 50 & 387 & 135 & 199 & 19 & 56 & 2508 & 5543 & 423187 \\
\hline $\mathrm{KR}$ & 802 & 13 & 32 & 1 & 26 & 11 & 10 & & & 885 & 584 & 107001 \\
\hline FR & 242 & 88 & 84 & 10 & 104 & 45 & 60 & 9 & 4 & 607 & 2795 & 126924 \\
\hline NL & 96 & 51 & 56 & 9 & 22 & 13 & 14 & 1 & 3 & 236 & 539 & 29009 \\
\hline $\mathrm{CA}$ & 51 & 39 & 49 & 11 & 59 & 22 & 17 & 3 & 2 & 233 & 549 & 35528 \\
\hline TW & 160 & 11 & 9 & 2 & 14 & 4 & & & & 195 & 122 & 20850 \\
\hline $\mathrm{CH}$ & 75 & 35 & 16 & 7 & 39 & 12 & 4 & 1 & 5 & 179 & 600 & 27081 \\
\hline DK & 5 & 5 & 152 & 2 & 17 & 4 & 1 & & & 177 & 175 & 7929 \\
\hline NO & 13 & 12 & 28 & 7 & 54 & 0.2 & 20 & 3 & 2 & 119 & 165 & 6362 \\
\hline$A U$ & 41 & 43 & 11 & 1 & 22 & 7 & 3 & & 3 & 112 & 132 & 10150 \\
\hline $\mathrm{FI}$ & 11 & 8 & 18 & 3 & 10 & 25 & 4 & & 7 & 82 & 399 & 20178 \\
\hline IL & 19 & 38 & 9 & 14 & 16 & 3 & 2 & & 3 & 82 & 59 & 11441 \\
\hline $\mathrm{BE}$ & 31 & 12 & 19 & 1 & 7 & 11 & 3 & & 1 & 79 & 212 & 13207 \\
\hline IN & 28 & 1 & 3 & & 1 & 6 & 6 & 0.3 & 1 & 45 & 22 & 4584 \\
\hline $\mathrm{RU}$ & 12 & 9 & 7 & & 7 & 2 & 2 & & 1 & 35 & 150 & 4617 \\
\hline GR & 8 & 10 & 5 & & 8 & & & & 1 & 24 & 8 & 990 \\
\hline BR & 0.3 & & 4 & & 14 & 5 & & & & 24 & 30 & 2322 \\
\hline $\mathrm{PT}$ & 3 & 7 & 2 & 1 & 6 & 1 & & 1 & & 19 & 17 & 565 \\
\hline
\end{tabular}


ENV/WKP(2010)16

Table 11. Patenting activity of inventor countries in selected CCMT fields (1988-2007) (continued)

\begin{tabular}{|c|c|c|c|c|c|c|c|c|c|c|c|c|}
\hline & $\begin{array}{c}\text { Solar } \\
\text { PV }\end{array}$ & $\begin{array}{c}\text { Solar } \\
\text { TH }\end{array}$ & Wind & Geo-thermal & $\begin{array}{l}\text { Hydro/ } \\
\text { Marine }\end{array}$ & Biofuels & $\begin{array}{c}\mathrm{CO} 2 \\
\text { Capture } \\
\end{array}$ & $\begin{array}{c}\mathrm{CO} 2 \\
\text { Storage } \\
\end{array}$ & IGCC & $\begin{array}{l}\text { Selected } \\
\text { CCMTs }\end{array}$ & $\begin{array}{c}\text { F\&N } \\
\text { Energy }\end{array}$ & $\begin{array}{c}\text { All_sectors } \\
\text { (TOTAL) }\end{array}$ \\
\hline$N Z$ & 3 & 5 & 1 & 1 & 3 & 1 & 2 & & & 13 & 11 & 1388 \\
\hline HK & 4 & 4 & 3 & & 3 & & 1 & & & 12 & 17 & 1976 \\
\hline TR & 3 & 3 & 2 & & 3 & & 1 & & & 10 & 8 & 566 \\
\hline $\mathrm{TH}$ & 6 & 5 & 4 & & & & & & & 10 & 4 & 253 \\
\hline$C Z$ & 2 & 2 & 1 & 1 & 3 & 2 & & & & 8 & 63 & 1788 \\
\hline PL & 0.2 & 3 & 2 & & 3 & & & & & 7 & 26 & 1149 \\
\hline $\begin{array}{l}\text { MX } \\
\text { World }\end{array}$ & 1 & 1 & & & 3 & 0.3 & 1 & & & 5 & 15 & 998 \\
\hline total & 8972 & 1639 & 2232 & 285 & 1902 & 731 & 616 & 54 & 190 & 15755 & 30235 & 2310472 \\
\hline
\end{tabular}

Note: Inventor countries selected include those where TOTAL $>1000$ or CCMT $>10$ (incl. 27 OECD countries and 10 non-OECD countries). Countries are ordered in descending order by their volume of CCMT patenting. The top five countries in each field are shown in bold. F\&N Energy = Fossil-fuel \& nuclear energy. TOTAL refers to the entire stock of CP patent applications in PATSTAT with priority dates during the given time period; note that for approx. $8.5 \%$ of all CPs the country of the inventor(s) is unknown. 
Table 12. CCMT patent intensity of inventor countries (\% share of patenting in an CCMT field on patenting overall (TOTAL), 1988-2007 annual average)

\begin{tabular}{|c|c|c|c|c|c|c|c|c|c|c|c|}
\hline & $\begin{array}{c}\text { Solar } \\
\text { PV }\end{array}$ & $\begin{array}{c}\text { Solar } \\
\text { TH }\end{array}$ & Wind & $\begin{array}{c}\text { Geo- } \\
\text { thermal }\end{array}$ & $\begin{array}{l}\text { Hydro/ } \\
\text { Marine }\end{array}$ & Biofuels & $\begin{array}{c}\mathrm{CO} 2 \\
\text { Capture }\end{array}$ & $\begin{array}{c}\mathrm{CO} 2 \\
\text { Storage }\end{array}$ & IGCC & $\begin{array}{r}\text { Selected } \\
\text { CCMTs }\end{array}$ & $\begin{array}{c}\text { F\&N } \\
\text { Energy }\end{array}$ \\
\hline $\mathrm{JP}$ & 0.57 & 0.02 & 0.03 & 0.00 & 0.03 & 0.02 & 0.02 & 0.00 & 0.01 & 0.68 & 0.83 \\
\hline US & 0.31 & 0.04 & 0.08 & 0.01 & 0.09 & 0.03 & 0.05 & 0.00 & 0.01 & 0.59 & 1.31 \\
\hline $\mathrm{DE}$ & 0.28 & 0.13 & 0.19 & 0.01 & 0.08 & 0.04 & 0.02 & 0.00 & 0.01 & 0.72 & 1.75 \\
\hline $\mathrm{KR}$ & 0.75 & 0.01 & 0.03 & 0.00 & 0.02 & 0.01 & 0.01 & 0.00 & 0.00 & 0.83 & 0.55 \\
\hline FR & 0.19 & 0.07 & 0.07 & 0.01 & 0.08 & 0.04 & 0.05 & 0.01 & 0.00 & 0.48 & 2.20 \\
\hline GB & 0.25 & 0.06 & 0.10 & 0.01 & 0.21 & 0.03 & 0.03 & 0.00 & 0.01 & 0.67 & 1.24 \\
\hline IT & 0.19 & 0.11 & 0.09 & 0.02 & 0.16 & 0.06 & 0.02 & 0.00 & 0.00 & 0.59 & 1.83 \\
\hline NL & 0.33 & 0.17 & 0.19 & 0.03 & 0.07 & 0.04 & 0.05 & 0.00 & 0.01 & 0.81 & 1.86 \\
\hline CA & 0.14 & 0.11 & 0.14 & 0.03 & 0.17 & 0.06 & 0.05 & 0.01 & 0.01 & 0.66 & 1.55 \\
\hline TW & 0.77 & 0.05 & 0.04 & 0.01 & 0.07 & 0.02 & 0.00 & 0.00 & 0.00 & 0.93 & 0.59 \\
\hline $\mathrm{CH}$ & 0.28 & 0.13 & 0.06 & 0.03 & 0.15 & 0.04 & 0.01 & 0.00 & 0.02 & 0.66 & 2.22 \\
\hline DK & 0.06 & 0.06 & 1.92 & 0.03 & 0.21 & 0.04 & 0.01 & 0.00 & 0.00 & 2.23 & 2.20 \\
\hline ES & 0.27 & 0.39 & 0.84 & 0.01 & 0.24 & 0.05 & 0.02 & 0.01 & 0.00 & 1.62 & 1.64 \\
\hline $\mathrm{CN}$ & 0.42 & 0.07 & 0.10 & 0.03 & 0.07 & 0.06 & 0.02 & 0.00 & 0.01 & 0.76 & 0.57 \\
\hline AT & 0.21 & 0.18 & 0.10 & 0.05 & 0.19 & 0.06 & 0.01 & 0.00 & 0.01 & 0.72 & 2.17 \\
\hline SE & 0.08 & 0.06 & 0.12 & 0.03 & 0.13 & 0.02 & 0.00 & 0.00 & 0.02 & 0.44 & 2.57 \\
\hline NO & 0.20 & 0.18 & 0.43 & 0.11 & 0.84 & 0.00 & 0.32 & 0.04 & 0.03 & 1.88 & 2.60 \\
\hline$A U$ & 0.40 & 0.42 & 0.10 & 0.01 & 0.21 & 0.07 & 0.03 & 0.00 & 0.02 & 1.10 & 1.30 \\
\hline $\mathrm{FI}$ & 0.05 & 0.04 & 0.09 & 0.01 & 0.05 & 0.12 & 0.02 & 0.00 & 0.03 & 0.41 & 1.98 \\
\hline IL & 0.17 & 0.33 & 0.08 & 0.12 & 0.14 & 0.03 & 0.02 & 0.00 & 0.03 & 0.71 & 0.51 \\
\hline $\mathrm{BE}$ & 0.23 & 0.09 & 0.14 & 0.01 & 0.06 & 0.08 & 0.02 & 0.00 & 0.01 & 0.60 & 1.61 \\
\hline IN & 0.61 & 0.02 & 0.07 & 0.00 & 0.02 & 0.13 & 0.12 & 0.01 & 0.01 & 0.98 & 0.49 \\
\hline$R U$ & 0.25 & 0.19 & 0.16 & 0.00 & 0.15 & 0.04 & 0.05 & 0.00 & 0.01 & 0.76 & 3.26 \\
\hline GR & 0.79 & 1.01 & 0.50 & 0.00 & 0.81 & 0.00 & 0.00 & 0.00 & 0.10 & 2.41 & 0.81 \\
\hline BR & 0.01 & 0.00 & 0.19 & 0.00 & 0.60 & 0.22 & 0.00 & 0.00 & 0.00 & 1.02 & 1.30 \\
\hline PT & 0.47 & 1.24 & 0.32 & 0.18 & 1.06 & 0.18 & 0.00 & 0.18 & 0.00 & 3.45 & 2.98 \\
\hline IE & 0.18 & 0.04 & 0.08 & 0.00 & 0.32 & 0.12 & 0.00 & 0.00 & 0.00 & 0.69 & 0.65 \\
\hline $\mathrm{HU}$ & 0.06 & 0.45 & 0.05 & 0.19 & 0.14 & 0.05 & 0.00 & 0.00 & 0.00 & 0.75 & 1.50 \\
\hline SG & 0.47 & 0.04 & 0.04 & 0.04 & 0.07 & 0.00 & 0.00 & 0.00 & 0.00 & 0.54 & 0.58 \\
\hline UA & 0.13 & 0.24 & 0.51 & 0.00 & 0.13 & 0.64 & 0.13 & 0.00 & 0.13 & 1.78 & 4.42 \\
\hline$N Z$ & 0.24 & 0.32 & 0.07 & 0.07 & 0.22 & 0.07 & 0.11 & 0.00 & 0.00 & 0.92 & 0.77 \\
\hline HK & 0.21 & 0.18 & 0.13 & 0.00 & 0.14 & 0.00 & 0.06 & 0.00 & 0.00 & 0.59 & 0.87 \\
\hline TR & 0.49 & 0.53 & 0.27 & 0.00 & 0.53 & 0.00 & 0.09 & 0.00 & 0.00 & 1.72 & 1.44 \\
\hline $\mathrm{TH}$ & 2.17 & 1.98 & 1.58 & 0.00 & 0.00 & 0.00 & 0.00 & 0.00 & 0.00 & 3.75 & 1.38 \\
\hline$C Z$ & 0.08 & 0.11 & 0.06 & 0.06 & 0.17 & 0.11 & 0.00 & 0.00 & 0.00 & 0.48 & 3.51 \\
\hline PL & 0.01 & 0.22 & 0.17 & 0.00 & 0.26 & 0.00 & 0.00 & 0.00 & 0.00 & 0.58 & 2.31 \\
\hline $\mathrm{MX}$ & 0.10 & 0.10 & 0.00 & 0.00 & 0.30 & 0.03 & 0.10 & 0.00 & 0.00 & 0.53 & 1.50 \\
\hline
\end{tabular}

Note: The top five countries in each field are shown in bold. 
Table 13. CCMT patenting per unit of GDP

(Number of CCMT claimed priorities per trillion USD in 2000 prices using PPP, 1988-2007 annual mean)

\begin{tabular}{|c|c|c|c|c|c|c|c|c|c|c|c|c|}
\hline & $\begin{array}{l}\text { Solar } \\
\text { PV }\end{array}$ & $\begin{array}{c}\text { Solar } \\
\text { TH }\end{array}$ & Wind & $\begin{array}{c}\text { Geo- } \\
\text { thermal }\end{array}$ & $\begin{array}{l}\text { Hydro/ } \\
\text { Marine }\end{array}$ & Biofuels & $\begin{array}{c}\mathrm{CO} 2 \\
\text { Capture }\end{array}$ & $\begin{array}{c}\mathrm{CO} 2 \\
\text { Storage } \\
\end{array}$ & IGCC & $\begin{array}{l}\text { Selected } \\
\text { CCMTs }\end{array}$ & $\begin{array}{c}\text { F\&N } \\
\text { Energy }\end{array}$ & $\begin{array}{c}\text { All_sectors } \\
\text { (TOTAL) }\end{array}$ \\
\hline$J P$ & 62.48 & 2.25 & 3.10 & 0.50 & 3.16 & 1.78 & 1.65 & 0.10 & 0.59 & 74.07 & 91.2 & 10967.4 \\
\hline US & 7.34 & 0.97 & 1.80 & 0.28 & 2.18 & 0.76 & 1.12 & 0.11 & 0.32 & 14.12 & 31.2 & 2381.8 \\
\hline $\mathrm{DE}$ & 23.36 & 11.29 & 16.29 & 1.10 & 6.49 & 3.32 & 1.99 & 0.09 & 0.68 & 59.98 & 146.5 & 8382.4 \\
\hline $\mathrm{KR}$ & 57.70 & 0.94 & 2.27 & 0.07 & 1.84 & 0.76 & 0.68 & 0.00 & 0.00 & 63.67 & 42.0 & 7700.6 \\
\hline FR & 8.42 & 3.07 & 2.90 & 0.35 & 3.60 & 1.58 & 2.08 & 0.30 & 0.13 & 21.07 & 97.1 & 4409.0 \\
\hline GB & 7.39 & 1.65 & 3.03 & 0.31 & 6.07 & 0.94 & 0.97 & 0.09 & 0.38 & 19.56 & 36.3 & 2933.5 \\
\hline IT & 3.17 & 1.92 & 1.47 & 0.27 & 2.73 & 0.97 & 0.31 & 0.00 & 0.04 & 9.86 & 30.8 & 1684.0 \\
\hline NL & 11.33 & 5.98 & 6.68 & 1.07 & 2.56 & 1.54 & 1.68 & 0.12 & 0.30 & 27.96 & 63.8 & 3437.6 \\
\hline CA & 3.21 & 2.44 & 3.08 & 0.69 & 3.70 & 1.39 & 1.04 & 0.18 & 0.15 & 14.55 & 34.3 & 2217.8 \\
\hline TW & 18.97 & 1.30 & 1.01 & 0.18 & 1.66 & 0.51 & 0.00 & 0.00 & 0.00 & 23.04 & 14.5 & 2468.9 \\
\hline $\mathrm{CH}$ & 17.12 & 7.96 & 3.58 & 1.60 & 9.03 & 2.67 & 0.88 & 0.30 & 1.03 & 40.86 & 137.1 & 6190.3 \\
\hline DK & 1.79 & 1.59 & 53.68 & 0.70 & 5.99 & 1.23 & 0.35 & 0.00 & 0.00 & 62.34 & 61.6 & 2793.8 \\
\hline ES & 1.80 & 2.62 & 5.60 & 0.06 & 1.58 & 0.34 & 0.11 & 0.06 & 0.00 & 10.85 & 11.0 & 669.6 \\
\hline $\mathrm{CN}$ & 0.88 & 0.14 & 0.21 & 0.06 & 0.15 & 0.12 & 0.04 & 0.00 & 0.01 & 1.56 & 1.2 & 206.8 \\
\hline AT & 9.20 & 8.06 & 4.56 & 2.45 & 8.61 & 2.57 & 0.28 & 0.00 & 0.35 & 31.99 & 97.1 & 4474.1 \\
\hline SE & 5.04 & 3.89 & 7.34 & 1.51 & 7.56 & 1.37 & 0.29 & 0.00 & 1.40 & 26.34 & 155.2 & 6041.7 \\
\hline NO & 4.37 & 3.89 & 9.30 & 2.37 & 18.09 & 0.07 & 6.85 & 0.85 & 0.74 & 40.36 & 56.0 & 2151.2 \\
\hline$A U$ & 4.17 & 4.35 & 1.07 & 0.10 & 2.20 & 0.70 & 0.32 & 0.00 & 0.26 & 11.43 & 13.5 & 1039.0 \\
\hline $\mathrm{FI}$ & 4.39 & 3.24 & 7.29 & 1.22 & 3.85 & 10.20 & 1.62 & 0.00 & 2.84 & 33.43 & 161.6 & 8176.6 \\
\hline IL & 7.20 & 14.26 & 3.38 & 5.07 & 6.00 & 1.13 & 0.75 & 0.00 & 1.13 & 30.65 & 22.1 & 4292.5 \\
\hline$B E$ & 5.80 & 2.27 & 3.59 & 0.19 & 1.39 & 2.02 & 0.57 & 0.00 & 0.23 & 14.88 & 40.1 & 2497.4 \\
\hline IN & 0.62 & 0.02 & 0.07 & 0.00 & 0.02 & 0.13 & 0.13 & 0.01 & 0.01 & 1.00 & 0.5 & 101.9 \\
\hline $\mathrm{RU}$ & 0.50 & 0.38 & 0.32 & 0.00 & 0.29 & 0.09 & 0.10 & 0.00 & 0.02 & 1.50 & 6.4 & 196.7 \\
\hline GR & 2.01 & 2.57 & 1.28 & 0.00 & 2.05 & 0.00 & 0.00 & 0.00 & 0.26 & 6.11 & 2.1 & 254.1 \\
\hline BR & 0.01 & 0.00 & 0.18 & 0.00 & 0.59 & 0.21 & 0.00 & 0.00 & 0.00 & 0.99 & 1.3 & 97.4 \\
\hline PT & 0.85 & 2.23 & 0.58 & 0.32 & 1.91 & 0.32 & 0.00 & 0.32 & 0.00 & 6.20 & 5.4 & 179.7 \\
\hline IE & 2.54 & 0.54 & 1.07 & 0.00 & 4.55 & 1.70 & 0.00 & 0.00 & 0.00 & 9.86 & 9.2 & 1419.8 \\
\hline $\mathrm{HU}$ & 0.54 & 3.85 & 0.41 & 1.62 & 1.22 & 0.41 & 0.00 & 0.00 & 0.00 & 6.42 & 12.8 & 853.0 \\
\hline SG & 7.91 & 0.62 & 0.62 & 0.62 & 1.24 & 0.00 & 0.00 & 0.00 & 0.00 & 9.15 & 9.8 & 1687.4 \\
\hline UA & 0.18 & 0.34 & 0.73 & 0.00 & 0.18 & 0.92 & 0.18 & 0.00 & 0.18 & 2.54 & 6.3 & 142.4 \\
\hline$N Z$ & 2.17 & 2.94 & 0.65 & 0.65 & 1.96 & 0.65 & 0.98 & 0.00 & 0.00 & 8.37 & 7.0 & 905.6 \\
\hline HK & 1.26 & 1.06 & 0.76 & 0.00 & 0.86 & 0.00 & 0.36 & 0.00 & 0.00 & 3.54 & 5.2 & 598.0 \\
\hline TR & 0.25 & 0.27 & 0.14 & 0.00 & 0.27 & 0.00 & 0.05 & 0.00 & 0.00 & 0.89 & 0.7 & 51.5 \\
\hline $\mathrm{TH}$ & 0.73 & 0.67 & 0.53 & 0.00 & 0.00 & 0.00 & 0.00 & 0.00 & 0.00 & 1.26 & 0.5 & 33.7 \\
\hline$C Z$ & 0.48 & 0.64 & 0.32 & 0.32 & 0.96 & 0.64 & 0.00 & 0.00 & 0.00 & 2.73 & 20.1 & 573.8 \\
\hline $\mathrm{PL}$ & 0.02 & 0.34 & 0.27 & 0.00 & 0.41 & 0.00 & 0.00 & 0.00 & 0.00 & 0.91 & 3.6 & 156.2 \\
\hline $\mathrm{MX}$ & 0.06 & 0.06 & 0.00 & 0.00 & 0.17 & 0.02 & 0.06 & 0.00 & 0.00 & 0.30 & 0.8 & 56.4 \\
\hline
\end{tabular}

Note: The top five countries in each field are shown in bold. 
Table 14. CCMT patenting per capita

(Number of CCMT claimed priorities per ten million inhabitants, 1988-2007 annual average)

\begin{tabular}{|c|c|c|c|c|c|c|c|c|c|c|c|c|}
\hline & $\begin{array}{l}\text { Solar } \\
\text { PV }\end{array}$ & $\begin{array}{c}\text { Solar } \\
\text { TH }\end{array}$ & Wind & $\begin{array}{c}\text { Geo- } \\
\text { thermal }\end{array}$ & $\begin{array}{l}\text { Hydro/ } \\
\text { Marine }\end{array}$ & Biofuels & $\begin{array}{c}\mathrm{CO} 2 \\
\text { Capture }\end{array}$ & $\begin{array}{c}\mathrm{CO} 2 \\
\text { Storage }\end{array}$ & IGCC & $\begin{array}{c}\text { Selected } \\
\text { CCMTs }\end{array}$ & $\begin{array}{c}\text { F\&N } \\
\text { Energy }\end{array}$ & $\begin{array}{c}\text { All_sectors } \\
\text { (TOTAL) }\end{array}$ \\
\hline JP & 15.65 & 0.56 & 0.78 & 0.13 & 0.79 & 0.44 & 0.41 & 0.02 & 0.15 & 18.55 & 22.8 & 2747.2 \\
\hline US & 2.38 & 0.31 & 0.58 & 0.09 & 0.71 & 0.25 & 0.36 & 0.04 & 0.10 & 4.58 & 10.1 & 772.3 \\
\hline $\mathrm{DE}$ & 5.72 & 2.76 & 3.99 & 0.27 & 1.59 & 0.81 & 0.49 & 0.02 & 0.17 & 14.68 & 35.9 & 2052.1 \\
\hline $\mathrm{KR}$ & 8.76 & 0.14 & 0.34 & 0.01 & 0.28 & 0.11 & 0.10 & 0.00 & 0.00 & 9.66 & 6.4 & 1168.8 \\
\hline FR & 2.01 & 0.73 & 0.69 & 0.08 & 0.86 & 0.38 & 0.50 & 0.07 & 0.03 & 5.03 & 23.2 & 1052.6 \\
\hline GB & 1.81 & 0.40 & 0.74 & 0.08 & 1.48 & 0.23 & 0.24 & 0.02 & 0.09 & 4.78 & 8.9 & 717.4 \\
\hline IT & 0.76 & 0.46 & 0.36 & 0.07 & 0.66 & 0.23 & 0.07 & 0.00 & 0.01 & 2.38 & 7.4 & 405.9 \\
\hline $\mathrm{NL}$ & 3.05 & 1.61 & 1.80 & 0.29 & 0.69 & 0.42 & 0.45 & 0.03 & 0.08 & 7.53 & 17.2 & 926.1 \\
\hline $\mathrm{CA}$ & 0.86 & 0.65 & 0.82 & 0.18 & 0.99 & 0.37 & 0.28 & 0.05 & 0.04 & 3.89 & 9.2 & 592.2 \\
\hline TW & 3.71 & 0.25 & 0.20 & 0.03 & 0.32 & 0.10 & 0.00 & 0.00 & 0.00 & 4.50 & 2.8 & 482.3 \\
\hline $\mathrm{CH}$ & 5.29 & 2.46 & 1.11 & 0.49 & 2.79 & 0.82 & 0.27 & 0.09 & 0.32 & 12.61 & 42.3 & 1910.9 \\
\hline DK & 0.48 & 0.43 & 14.41 & 0.19 & 1.61 & 0.33 & 0.09 & 0.00 & 0.00 & 16.74 & 16.5 & 750.0 \\
\hline ES & 0.36 & 0.52 & 1.11 & 0.01 & 0.31 & 0.07 & 0.02 & 0.01 & 0.00 & 2.14 & 2.2 & 132.4 \\
\hline $\mathrm{CN}$ & 0.03 & 0.01 & 0.01 & 0.00 & 0.01 & 0.00 & 0.00 & 0.00 & 0.00 & 0.06 & 0.0 & 7.7 \\
\hline AT & 2.47 & 2.16 & 1.22 & 0.66 & 2.31 & 0.69 & 0.08 & 0.00 & 0.09 & 8.59 & 26.1 & 1200.6 \\
\hline SE & 1.32 & 1.02 & 1.93 & 0.40 & 1.98 & 0.36 & 0.08 & 0.00 & 0.37 & 6.92 & 40.7 & 1586.3 \\
\hline NO & 1.46 & 1.30 & 3.10 & 0.79 & 6.04 & 0.02 & 2.29 & 0.28 & 0.25 & 13.47 & 18.7 & 718.0 \\
\hline$A U$ & 1.08 & 1.13 & 0.28 & 0.03 & 0.57 & 0.18 & 0.08 & 0.00 & 0.07 & 2.97 & 3.5 & 270.1 \\
\hline $\mathrm{FI}$ & 1.06 & 0.78 & 1.75 & 0.29 & 0.93 & 2.45 & 0.39 & 0.00 & 0.68 & 8.04 & 38.9 & 1966.1 \\
\hline IL & 1.63 & 3.24 & 0.77 & 1.15 & 1.36 & 0.26 & 0.17 & 0.00 & 0.26 & 6.96 & 5.0 & 974.0 \\
\hline $\mathrm{BE}$ & 1.50 & 0.59 & 0.93 & 0.05 & 0.36 & 0.52 & 0.15 & 0.00 & 0.06 & 3.85 & 10.4 & 646.6 \\
\hline IN & 0.01 & 0.00 & 0.00 & 0.00 & 0.00 & 0.00 & 0.00 & 0.00 & 0.00 & 0.02 & 0.0 & 2.4 \\
\hline $\mathrm{RU}$ & 0.04 & 0.03 & 0.03 & 0.00 & 0.02 & 0.01 & 0.01 & 0.00 & 0.00 & 0.12 & 0.5 & 15.8 \\
\hline GR & 0.36 & 0.46 & 0.23 & 0.00 & 0.37 & 0.00 & 0.00 & 0.00 & 0.05 & 1.11 & 0.4 & 46.0 \\
\hline $\mathrm{BR}$ & 0.00 & 0.00 & 0.01 & 0.00 & 0.04 & 0.01 & 0.00 & 0.00 & 0.00 & 0.07 & 0.1 & 6.9 \\
\hline PT & 0.13 & 0.34 & 0.09 & 0.05 & 0.29 & 0.05 & 0.00 & 0.05 & 0.00 & 0.96 & 0.8 & 27.7 \\
\hline IE & 0.63 & 0.13 & 0.26 & 0.00 & 1.13 & 0.42 & 0.00 & 0.00 & 0.00 & 2.44 & 2.3 & 350.9 \\
\hline $\mathrm{HU}$ & 0.07 & 0.46 & 0.05 & 0.20 & 0.15 & 0.05 & 0.00 & 0.00 & 0.00 & 0.77 & 1.5 & 102.6 \\
\hline SG & 1.71 & 0.13 & 0.13 & 0.13 & 0.27 & 0.00 & 0.00 & 0.00 & 0.00 & 1.98 & 2.1 & 364.2 \\
\hline UA & 0.01 & 0.02 & 0.04 & 0.00 & 0.01 & 0.05 & 0.01 & 0.00 & 0.01 & 0.14 & 0.3 & 7.8 \\
\hline$N Z$ & 0.44 & 0.60 & 0.13 & 0.13 & 0.40 & 0.13 & 0.20 & 0.00 & 0.00 & 1.70 & 1.4 & 184.4 \\
\hline HK & 0.33 & 0.28 & 0.20 & 0.00 & 0.22 & 0.00 & 0.09 & 0.00 & 0.00 & 0.92 & 1.4 & 155.6 \\
\hline TR & 0.02 & 0.02 & 0.01 & 0.00 & 0.02 & 0.00 & 0.00 & 0.00 & 0.00 & 0.08 & 0.1 & 4.4 \\
\hline $\mathrm{TH}$ & 0.05 & 0.04 & 0.03 & 0.00 & 0.00 & 0.00 & 0.00 & 0.00 & 0.00 & 0.08 & 0.0 & 2.1 \\
\hline$C Z$ & 0.07 & 0.10 & 0.05 & 0.05 & 0.15 & 0.10 & 0.00 & 0.00 & 0.00 & 0.41 & 3.0 & 86.9 \\
\hline PL & 0.00 & 0.03 & 0.03 & 0.00 & 0.04 & 0.00 & 0.00 & 0.00 & 0.00 & 0.09 & 0.3 & 15.0 \\
\hline$M X$ & 0.01 & 0.01 & 0.00 & 0.00 & 0.02 & 0.00 & 0.01 & 0.00 & 0.00 & 0.03 & 0.1 & 5.3 \\
\hline
\end{tabular}

Note: The top five countries in each field are shown in bold. 
Table 15. CCMT patenting per dollar of general R\&D

(Number of CCMT claimed priorities per unit of Gross Domestic Expenditures on R\&D (GERD) in billion USD using 2000 prices and PPP, 1988-2007 annual average)

\begin{tabular}{|c|c|c|c|c|c|c|c|c|c|c|c|c|}
\hline & $\begin{array}{c}\text { Solar } \\
\text { PV }\end{array}$ & $\begin{array}{c}\text { Solar } \\
\text { TH }\end{array}$ & Wind & $\begin{array}{c}\text { Geo- } \\
\text { thermal }\end{array}$ & $\begin{array}{l}\text { Hydro/ } \\
\text { Marine }\end{array}$ & Biofuels & $\begin{array}{c}\text { CO2 } \\
\text { Capture }\end{array}$ & $\begin{array}{c}\mathrm{CO} 2 \\
\text { Storage }\end{array}$ & IGCC & $\begin{array}{c}\text { Selected } \\
\text { CCMTs }\end{array}$ & $\begin{array}{c}\text { F\&N } \\
\text { Energy }\end{array}$ & $\begin{array}{c}\text { All_sectors } \\
\text { (TOTAL) }\end{array}$ \\
\hline $\mathrm{JP}$ & 2.05 & 0.07 & 0.10 & 0.02 & 0.10 & 0.06 & 0.05 & 0.00 & 0.02 & 2.43 & 2.99 & 359.8 \\
\hline US & 0.28 & 0.04 & 0.07 & 0.01 & 0.08 & 0.03 & 0.04 & 0.00 & 0.01 & 0.54 & 1.19 & 90.6 \\
\hline $\mathrm{DE}$ & 0.97 & 0.47 & 0.68 & 0.05 & 0.27 & 0.14 & 0.08 & 0.00 & 0.03 & 2.50 & 6.10 & 349.0 \\
\hline $\mathrm{KR}$ & 2.06 & 0.03 & 0.08 & 0.00 & 0.07 & 0.03 & 0.02 & 0.00 & 0.00 & 2.27 & 1.50 & 274.4 \\
\hline FR & 0.38 & 0.14 & 0.13 & 0.02 & 0.16 & 0.07 & 0.09 & 0.01 & 0.01 & 0.95 & 4.40 & 199.8 \\
\hline GB & 0.40 & 0.09 & 0.16 & 0.02 & 0.33 & 0.05 & 0.05 & 0.01 & 0.02 & 1.05 & 1.95 & 157.9 \\
\hline IT & 0.29 & 0.18 & 0.14 & 0.02 & 0.25 & 0.09 & 0.03 & 0.00 & 0.00 & 0.91 & 2.83 & 154.8 \\
\hline $\mathrm{NL}$ & 0.61 & 0.32 & 0.36 & 0.06 & 0.14 & 0.08 & 0.09 & 0.01 & 0.02 & 1.49 & 3.41 & 183.8 \\
\hline CA & 0.18 & 0.14 & 0.17 & 0.04 & 0.20 & 0.08 & 0.06 & 0.01 & 0.01 & 0.80 & 1.89 & 122.5 \\
\hline TW & 0.81 & 0.06 & 0.04 & 0.01 & 0.07 & 0.02 & 0.00 & 0.00 & 0.00 & 0.98 & 0.62 & 105.4 \\
\hline $\mathrm{CH}$ & 0.65 & 0.30 & 0.14 & 0.06 & 0.34 & 0.10 & 0.03 & 0.01 & 0.04 & 1.56 & 5.23 & 235.9 \\
\hline DK & 0.09 & 0.08 & 2.57 & 0.03 & 0.29 & 0.06 & 0.02 & 0.00 & 0.00 & 2.98 & 2.95 & 133.7 \\
\hline ES & 0.19 & 0.28 & 0.60 & 0.01 & 0.17 & 0.04 & 0.01 & 0.01 & 0.00 & 1.16 & 1.17 & 71.5 \\
\hline $\mathrm{CN}$ & 0.13 & 0.02 & 0.03 & 0.01 & 0.02 & 0.02 & 0.01 & 0.00 & 0.00 & 0.23 & 0.18 & 30.8 \\
\hline AT & 0.49 & 0.43 & 0.24 & 0.13 & 0.46 & 0.14 & 0.01 & 0.00 & 0.02 & 1.71 & 5.18 & 238.5 \\
\hline SE & 0.14 & 0.11 & 0.20 & 0.04 & 0.21 & 0.04 & 0.01 & 0.00 & 0.04 & 0.72 & 4.25 & 165.4 \\
\hline $\mathrm{NO}$ & 0.26 & 0.23 & 0.56 & 0.14 & 1.09 & 0.00 & 0.41 & 0.05 & 0.04 & 2.44 & 3.38 & 129.9 \\
\hline$A U$ & 0.27 & 0.28 & 0.07 & 0.01 & 0.14 & 0.04 & 0.02 & 0.00 & 0.02 & 0.73 & 0.86 & 66.3 \\
\hline $\mathrm{FI}$ & 0.16 & 0.11 & 0.26 & 0.04 & 0.14 & 0.36 & 0.06 & 0.00 & 0.10 & 1.18 & 5.71 & 289.1 \\
\hline IL & 0.19 & 0.38 & 0.09 & 0.13 & 0.16 & 0.03 & 0.02 & 0.00 & 0.03 & 0.81 & 0.58 & 113.2 \\
\hline $\mathrm{BE}$ & 0.32 & 0.12 & 0.20 & 0.01 & 0.08 & 0.11 & 0.03 & 0.00 & 0.01 & 0.81 & 2.18 & 135.7 \\
\hline$R U$ & 0.04 & 0.03 & 0.03 & 0.00 & 0.02 & 0.01 & 0.01 & 0.00 & 0.00 & 0.12 & 0.51 & 15.7 \\
\hline GR & 0.39 & 0.49 & 0.25 & 0.00 & 0.40 & 0.00 & 0.00 & 0.00 & 0.05 & 1.18 & 0.40 & 49.0 \\
\hline PT & 0.12 & 0.32 & 0.08 & 0.05 & 0.27 & 0.05 & 0.00 & 0.05 & 0.00 & 0.89 & 0.77 & 25.8 \\
\hline IE & 0.22 & 0.05 & 0.09 & 0.00 & 0.39 & 0.14 & 0.00 & 0.00 & 0.00 & 0.84 & 0.79 & 121.4 \\
\hline $\mathrm{HU}$ & 0.06 & 0.44 & 0.05 & 0.18 & 0.14 & 0.05 & 0.00 & 0.00 & 0.00 & 0.73 & 1.46 & 97.1 \\
\hline SG & 0.24 & 0.02 & 0.02 & 0.02 & 0.04 & 0.00 & 0.00 & 0.00 & 0.00 & 0.28 & 0.30 & 51.7 \\
\hline$N Z$ & 0.21 & 0.28 & 0.06 & 0.06 & 0.19 & 0.06 & 0.09 & 0.00 & 0.00 & 0.81 & 0.67 & 87.1 \\
\hline TR & 0.05 & 0.06 & 0.03 & 0.00 & 0.06 & 0.00 & 0.01 & 0.00 & 0.00 & 0.19 & 0.16 & 10.8 \\
\hline$C Z$ & 0.04 & 0.05 & 0.02 & 0.02 & 0.07 & 0.05 & 0.00 & 0.00 & 0.00 & 0.21 & 1.56 & 44.5 \\
\hline PL & 0.00 & 0.05 & 0.04 & 0.00 & 0.06 & 0.00 & 0.00 & 0.00 & 0.00 & 0.14 & 0.56 & 24.1 \\
\hline SK & 0.00 & 0.01 & 0.00 & 0.00 & 0.01 & 0.00 & 0.00 & 0.00 & 0.00 & 0.02 & 0.00 & 2.7 \\
\hline ZA & 0.00 & 0.02 & 0.07 & 0.00 & 0.04 & 0.00 & 0.00 & 0.00 & 0.00 & 0.13 & 0.00 & 15.1 \\
\hline $\mathrm{MX}$ & 0.02 & 0.02 & 0.00 & 0.00 & 0.05 & 0.01 & 0.02 & 0.00 & 0.00 & 0.08 & 0.23 & 15.6 \\
\hline AR & 0.05 & 0.03 & 0.07 & 0.00 & 0.03 & 0.00 & 0.02 & 0.00 & 0.00 & 0.16 & 0.00 & 13.0 \\
\hline $\mathrm{SI}$ & 0.07 & 0.20 & 0.00 & 0.00 & 0.10 & 0.00 & 0.00 & 0.00 & 0.00 & 0.37 & 0.00 & 90.0 \\
\hline RO & 0.03 & 0.00 & 0.00 & 0.00 & 0.02 & 0.03 & 0.00 & 0.00 & 0.00 & 0.09 & 0.00 & 16.4 \\
\hline IS & 0.00 & 0.00 & 0.30 & 0.00 & 0.00 & 0.00 & 0.00 & 0.00 & 0.00 & 0.30 & 0.00 & 67.1 \\
\hline
\end{tabular}

Note: Inventor countries selected include those for which GERD data were available. Countries are ordered in descending order by their volume of CCMT patenting. The top five countries in each field are shown in bold. 
Figure 30. Invention in solar PV technologies (1970-2007)

(\% share, 3-year moving average)

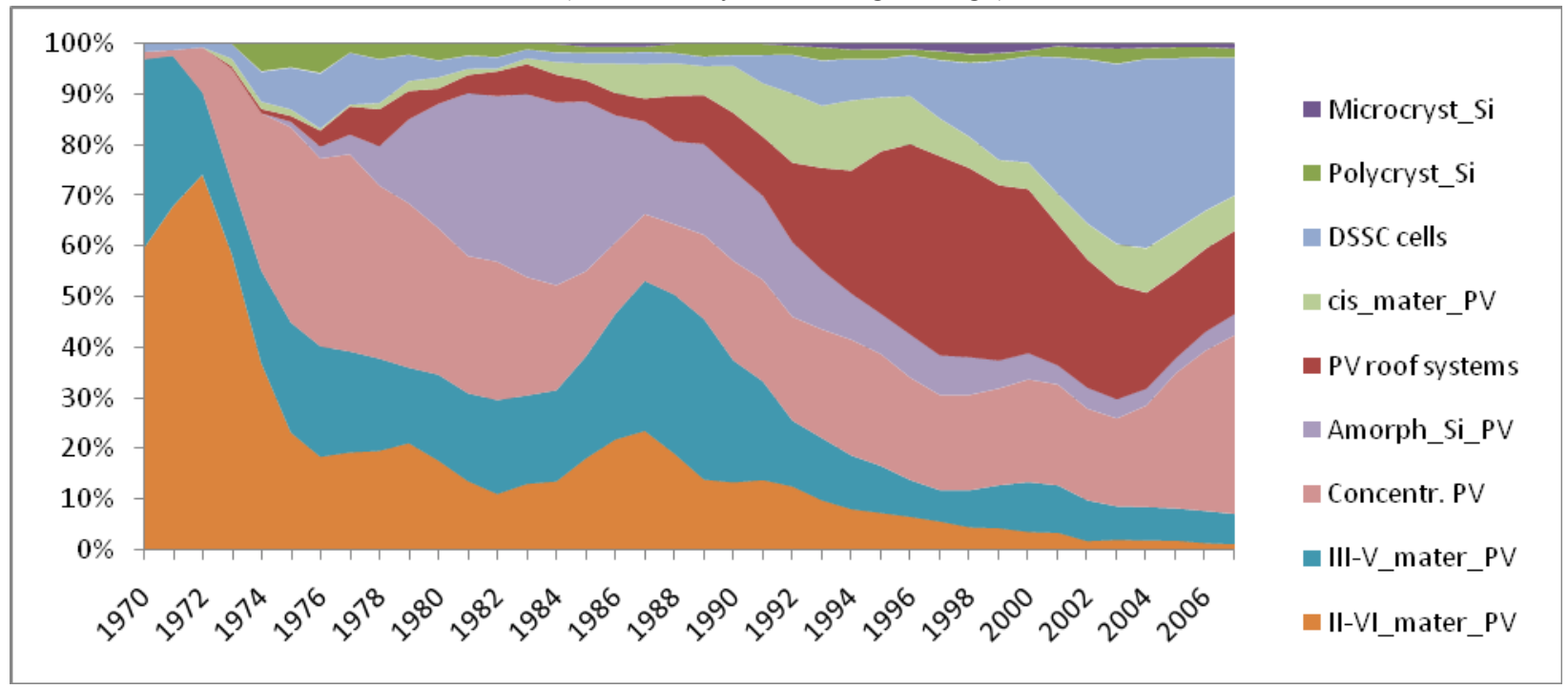

Figure 31. Invention in solar thermal technologies (1970-2007

( $\%$ share, 3-year moving average)

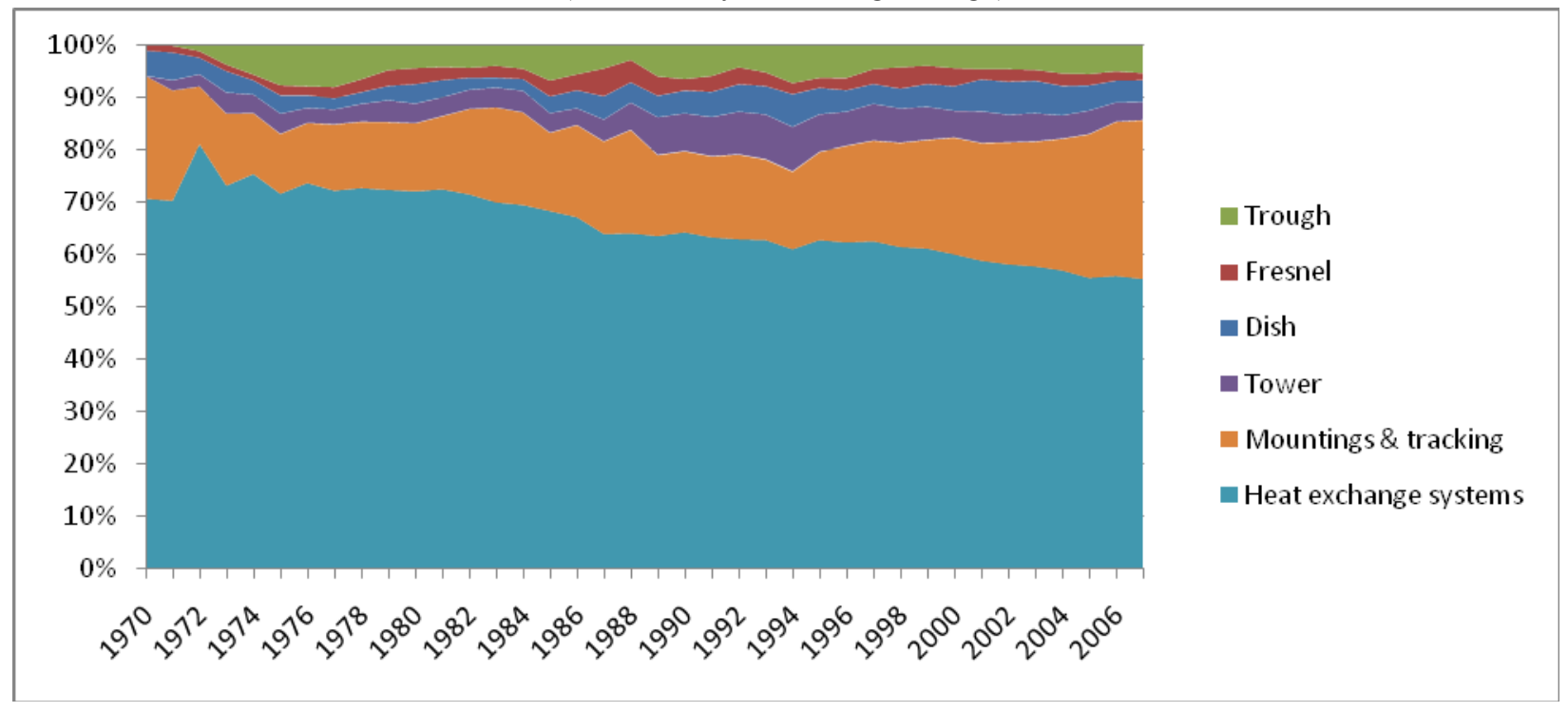


Figure 32. Invention in geothermal energy

(Share on world patenting by inventor country, based on count of CPs worldwide)

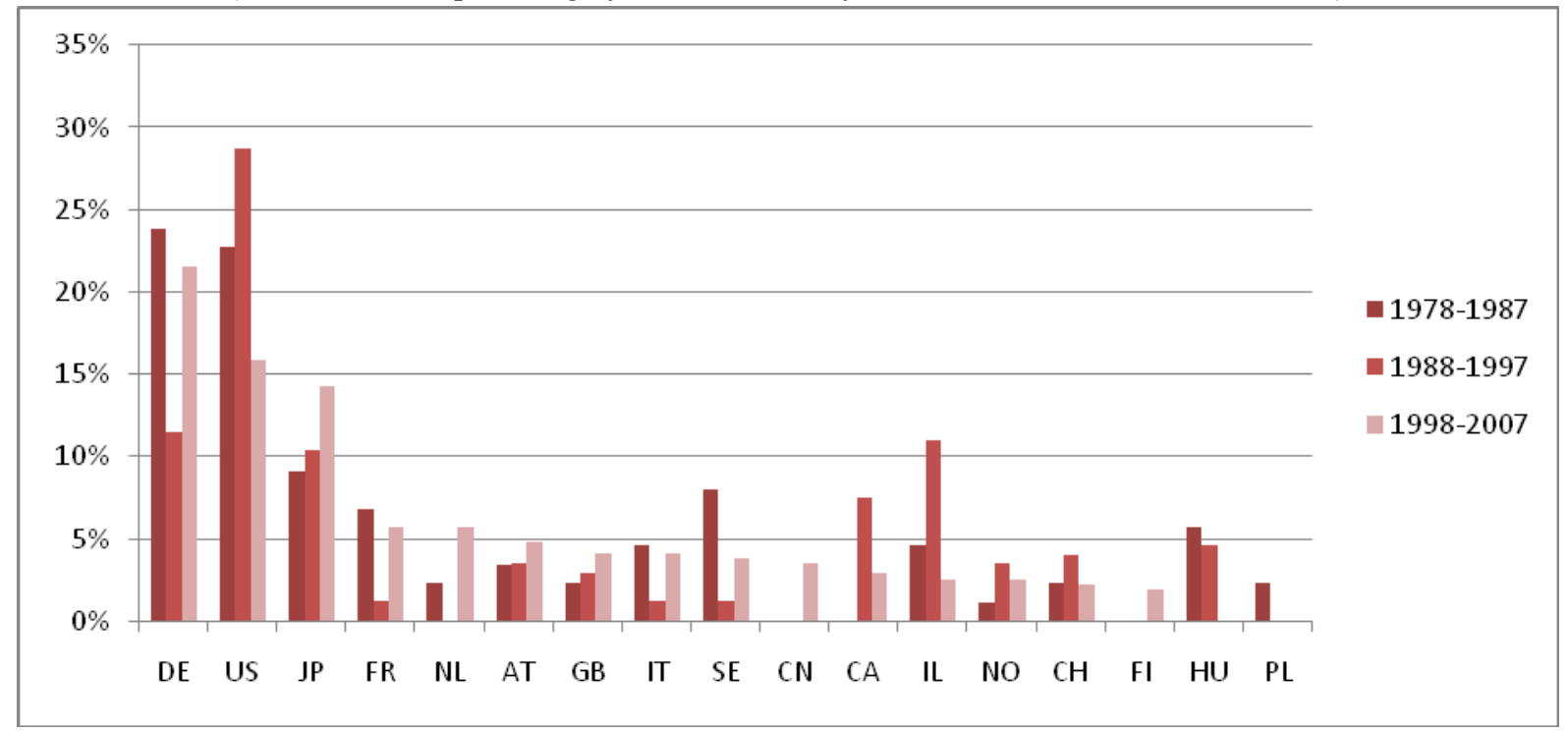

Figure 33. Invention in solar PV energy

(Share on world patenting by inventor country, based on count of CPs worldwide)

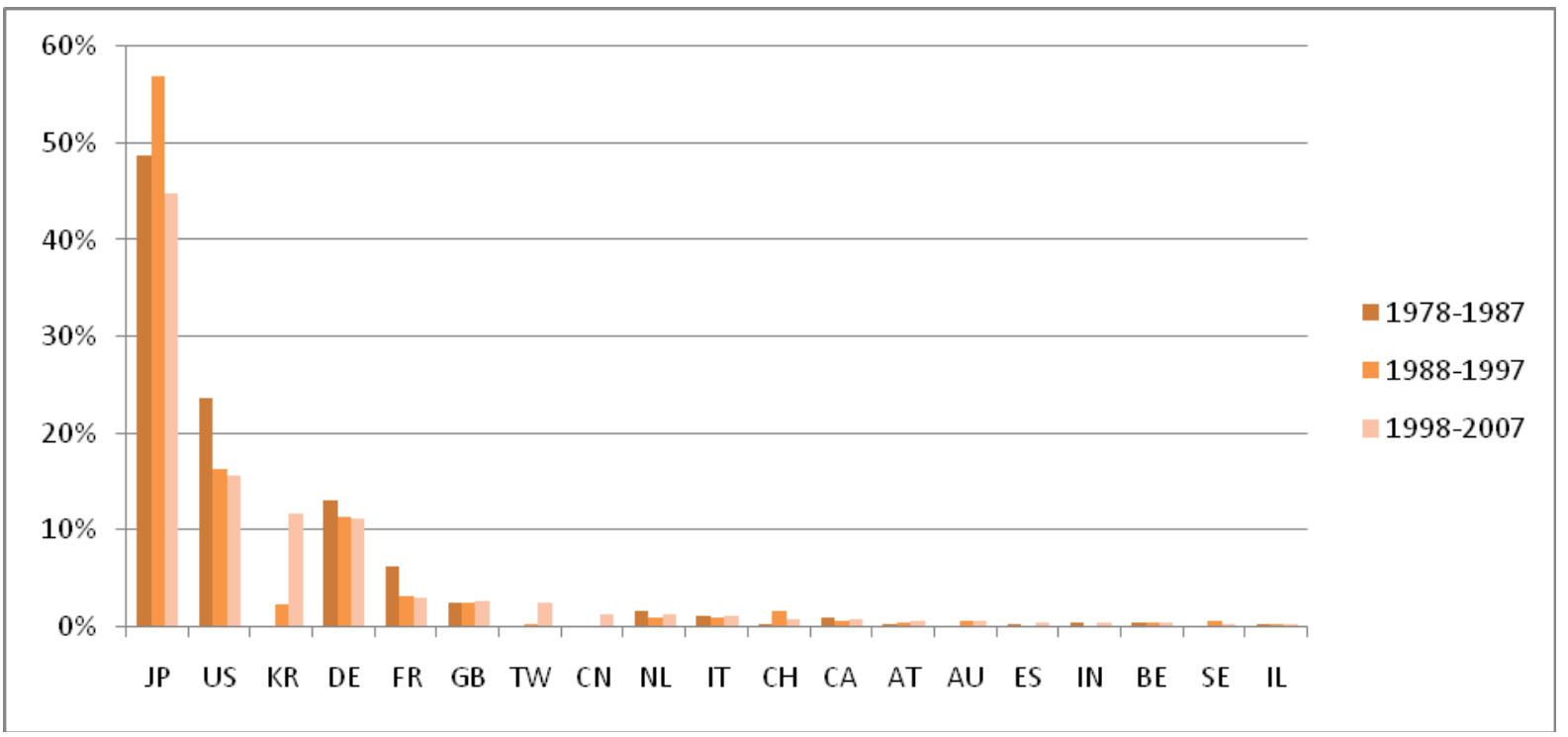

Source: Invention in solar PV energy 
Figure 34. Invention in wind energy

(Share on world patenting by inventor country, based on count of CPs worldwide)

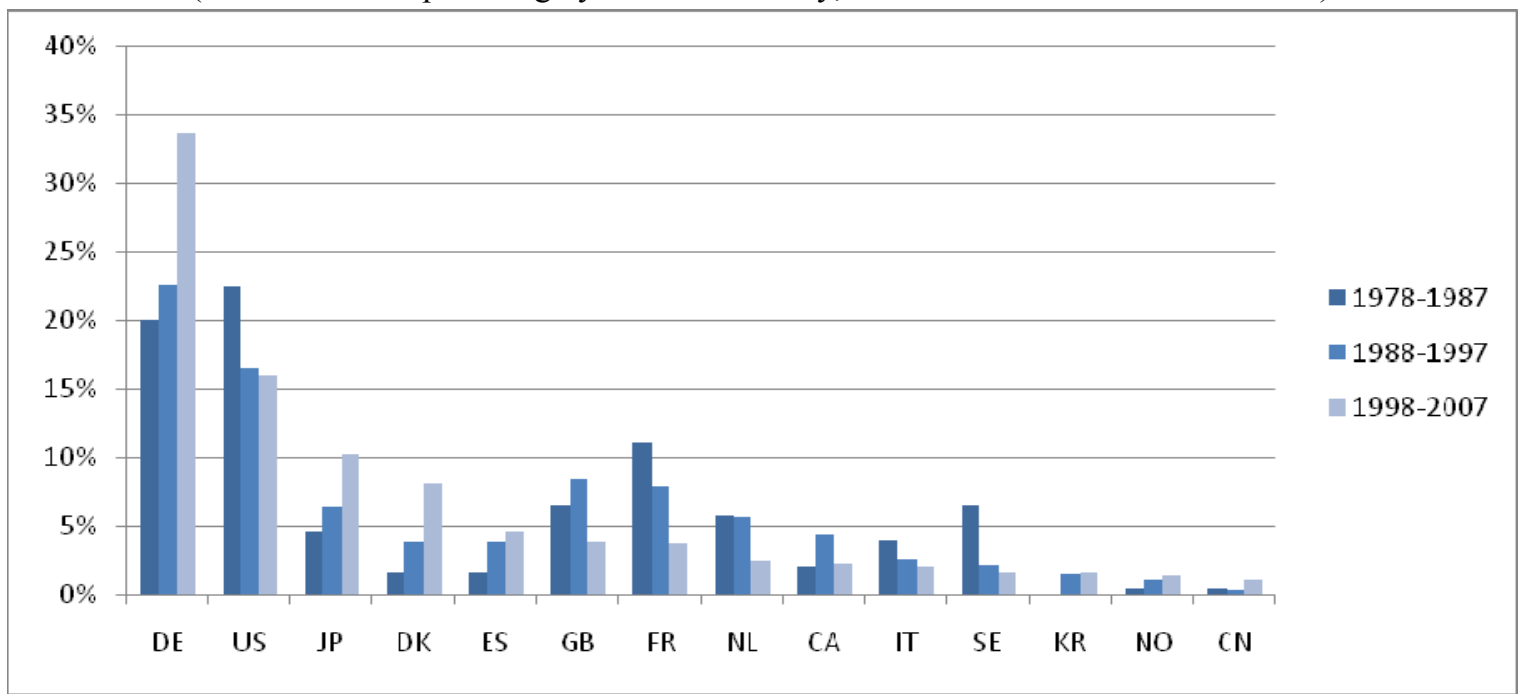

Figure 35. Invention in $\mathrm{CO} 2$ capture

(Share on world patenting by inventor country, based on count of CPs worldwide)

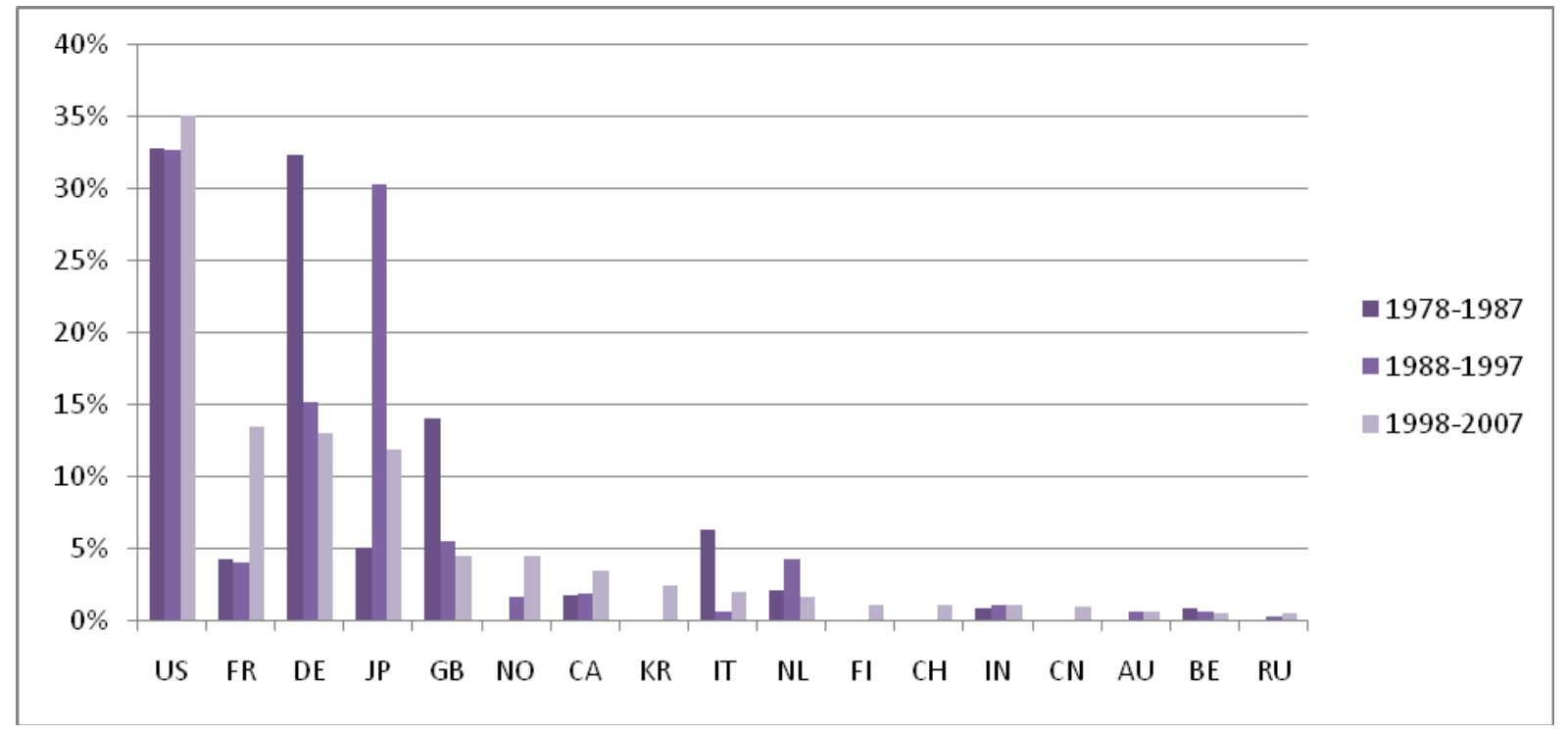


Figure 36. Invention in IGCC

(Share on world patenting by inventor country, based on count of CPs worldwide)

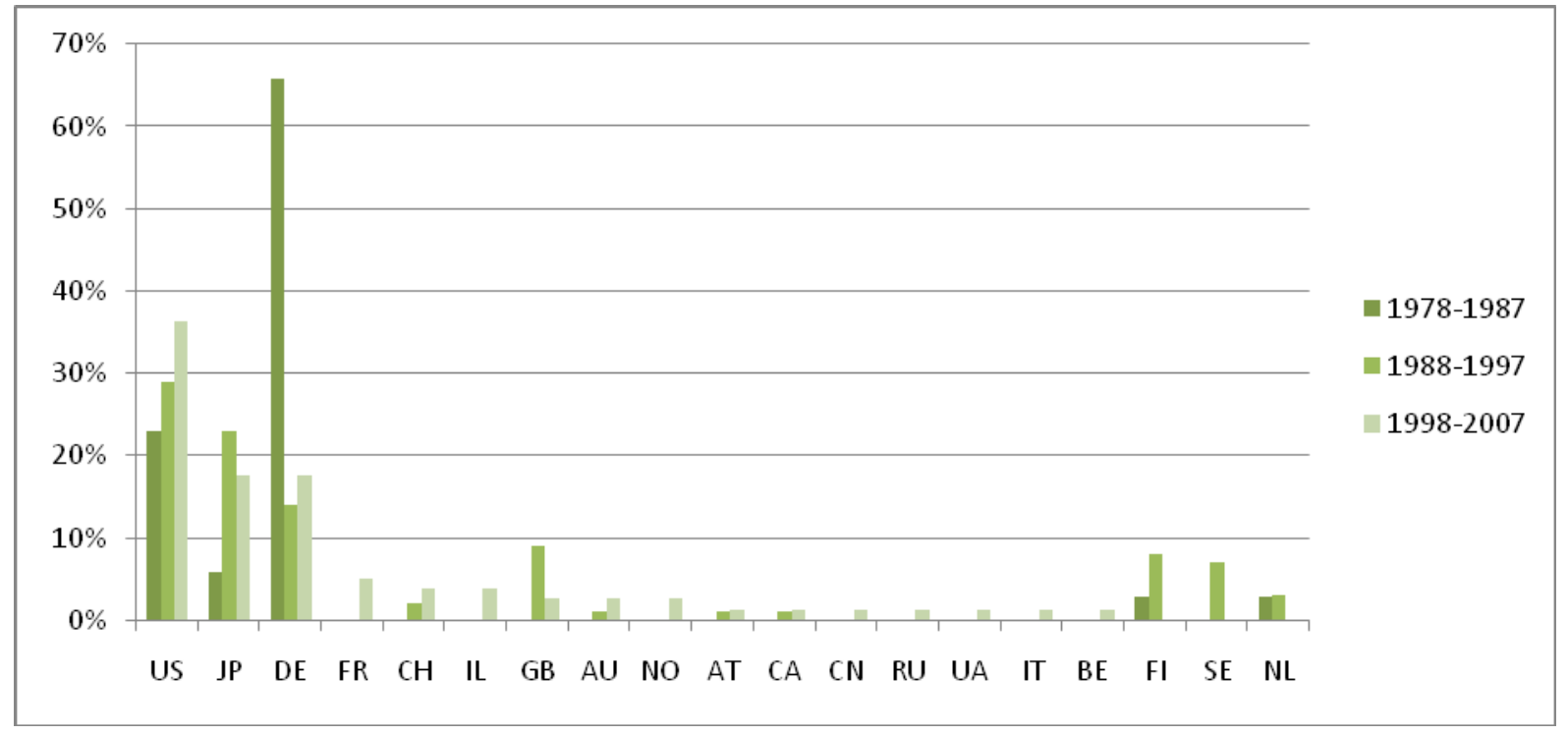

Table 16. The most CCMT-intensive application authorities

(Share of CCMT on TOTAL, by priority year)

\begin{tabular}{llllll}
\hline \multicolumn{2}{c}{$1978-1987$} & \multicolumn{2}{c}{$1988-1997$} & \multicolumn{2}{c}{$1998-2007$} \\
\hline AU & $1.05 \%$ & AU & $0.52 \%$ & KR & $1.14 \%$ \\
JP & $0.74 \%$ & US & $0.44 \%$ & CN & $1.00 \%$ \\
US & $0.66 \%$ & EP & $0.38 \%$ & JP & $0.97 \%$ \\
EP & $0.65 \%$ & ES & $0.36 \%$ & US & $0.97 \%$ \\
CA & $0.64 \%$ & JP & $0.35 \%$ & AU & $0.95 \%$
\end{tabular}

Note: Only offices with TOTAL $>100,000$ applications were considered.

\begin{tabular}{lrlrll}
\hline \multicolumn{2}{c}{$1978-1987$} & \multicolumn{2}{c}{$1988-1997$} & \multicolumn{2}{c}{$1998-2007$} \\
\hline OA & $3.21 \%$ & OA & $1.09 \%$ & MA & $3.22 \%$ \\
MA & $2.53 \%$ & MA & $0.83 \%$ & AP & $2.90 \%$ \\
IN & $2.13 \%$ & PH & $0.62 \%$ & IS & $1.54 \%$ \\
IL & $1.63 \%$ & ID & $0.59 \%$ & AR & $1.47 \%$ \\
EG & $1.43 \%$ & NL & $0.56 \%$ & SG & $1.43 \%$
\end{tabular}

Note: Only offices with TOTAL $>1,000$ applications were considered. 


\section{APPENDIX D. SELECTED POLICY MEASURES AND PATENT COUNTS}

\section{Figure 37. Targets for renewable energy certificates (REC \%) and CCMT patenting (CP)}
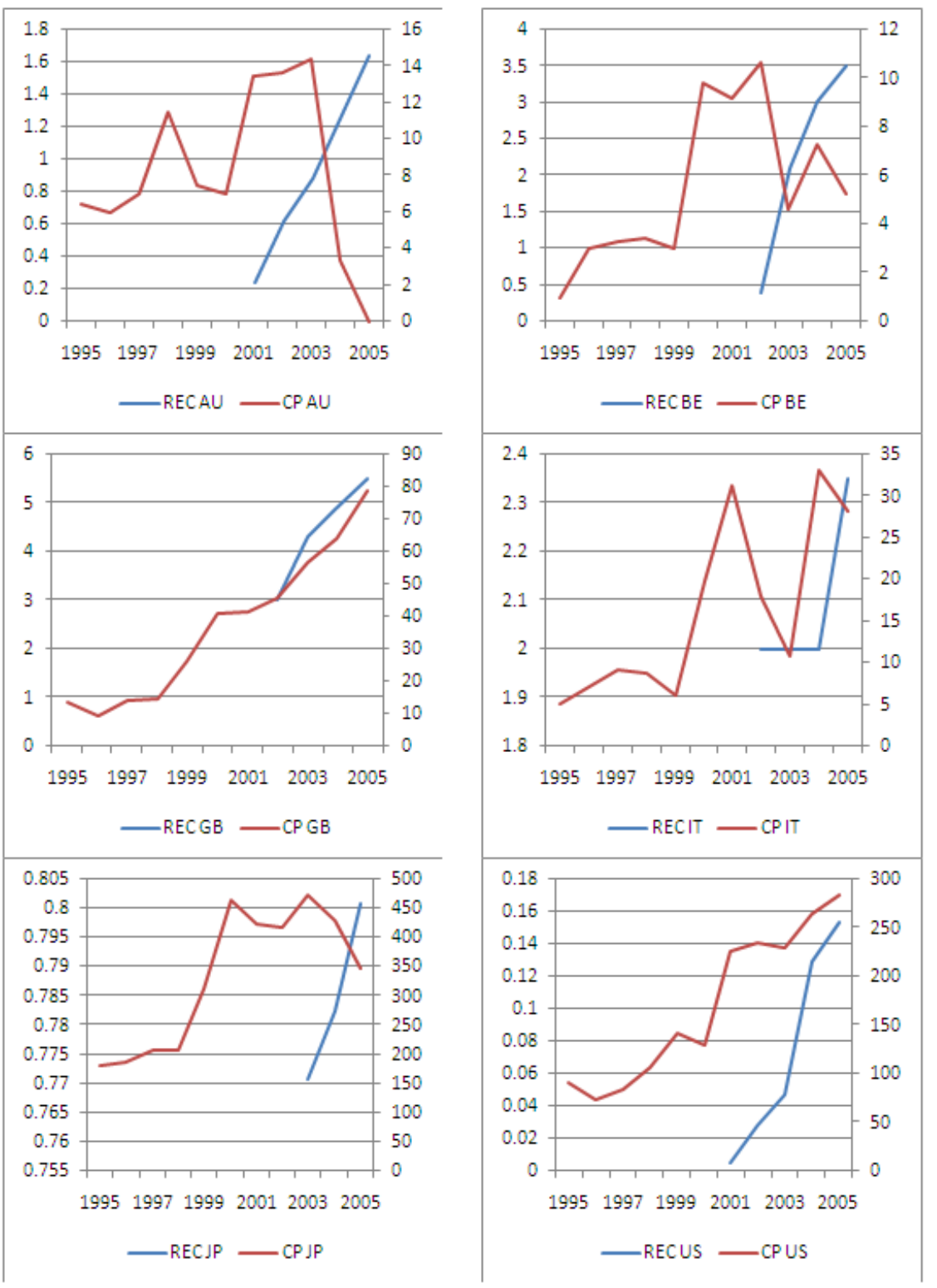

While there is a close relationship for some countries (e.g. Italy, Great Britain, and the US) this is not always the case.

Similar data is presented with respect to feed-in tariffs in Figure 38 below. In this case the focus is on solar PV technologies for five major inventor countries. While two of them - DE and FR - have introduced preferential feed-in tariffs for electricity from solar PV, the others (GB, US and JP) have not. There is no clear distinction between the groups of countries. 
Figure 38. Feed-in tariffs (FIT) and patenting (CP) in solar PV

(FIT in 2000 USD, patent counts shown as 3-year moving average, indexed on 1990=1.0)

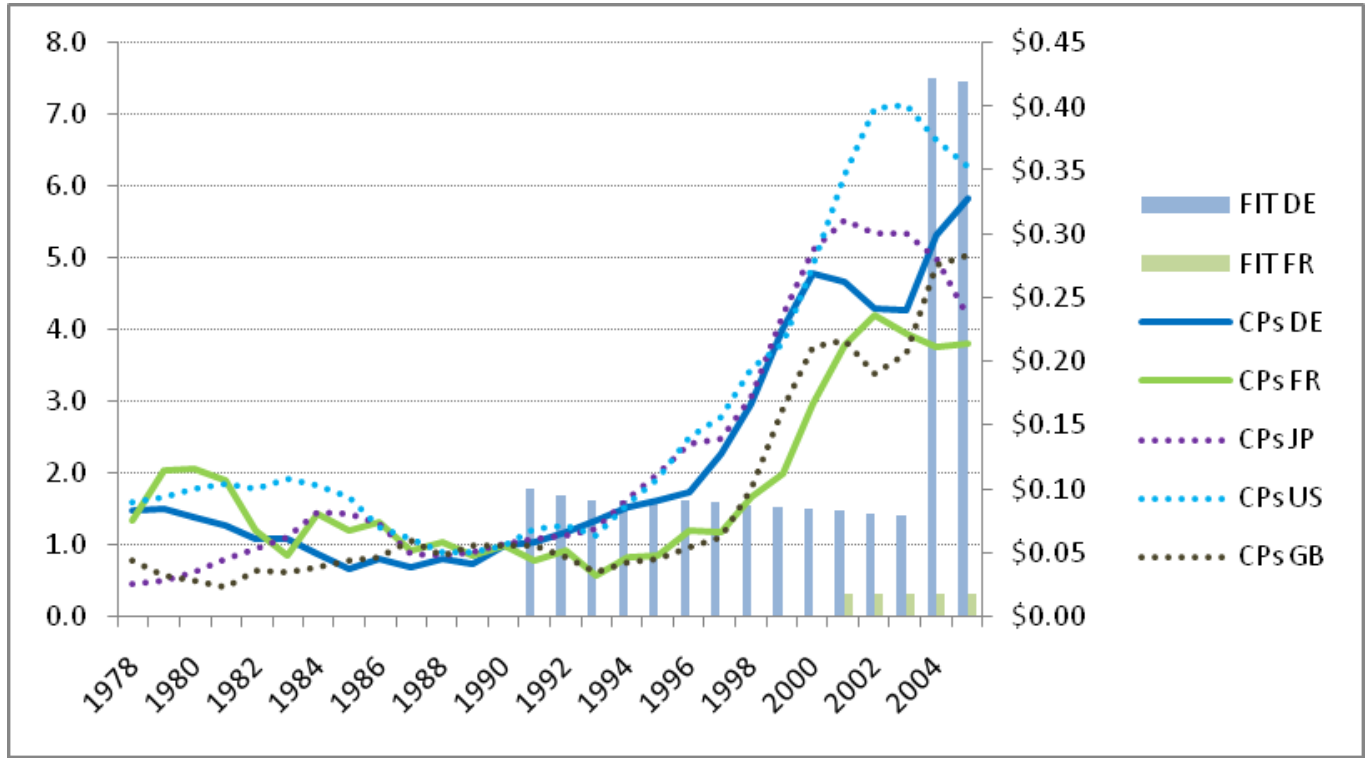

The six major inventor countries in wind power are presented in Figure 39. Three of them - DE, DK, ES - have introduced preferential feed-in tariffs for wind power, while the others (US, JP, GB) have not. Once again, there is no clear distinction between the groups of countries.

Figure 39. Feed-in tariffs (FIT) and patenting (CP) in wind power

(FIT in 2000 USD, patent counts shown as 3-year moving average, indexed on 1990=1.0)

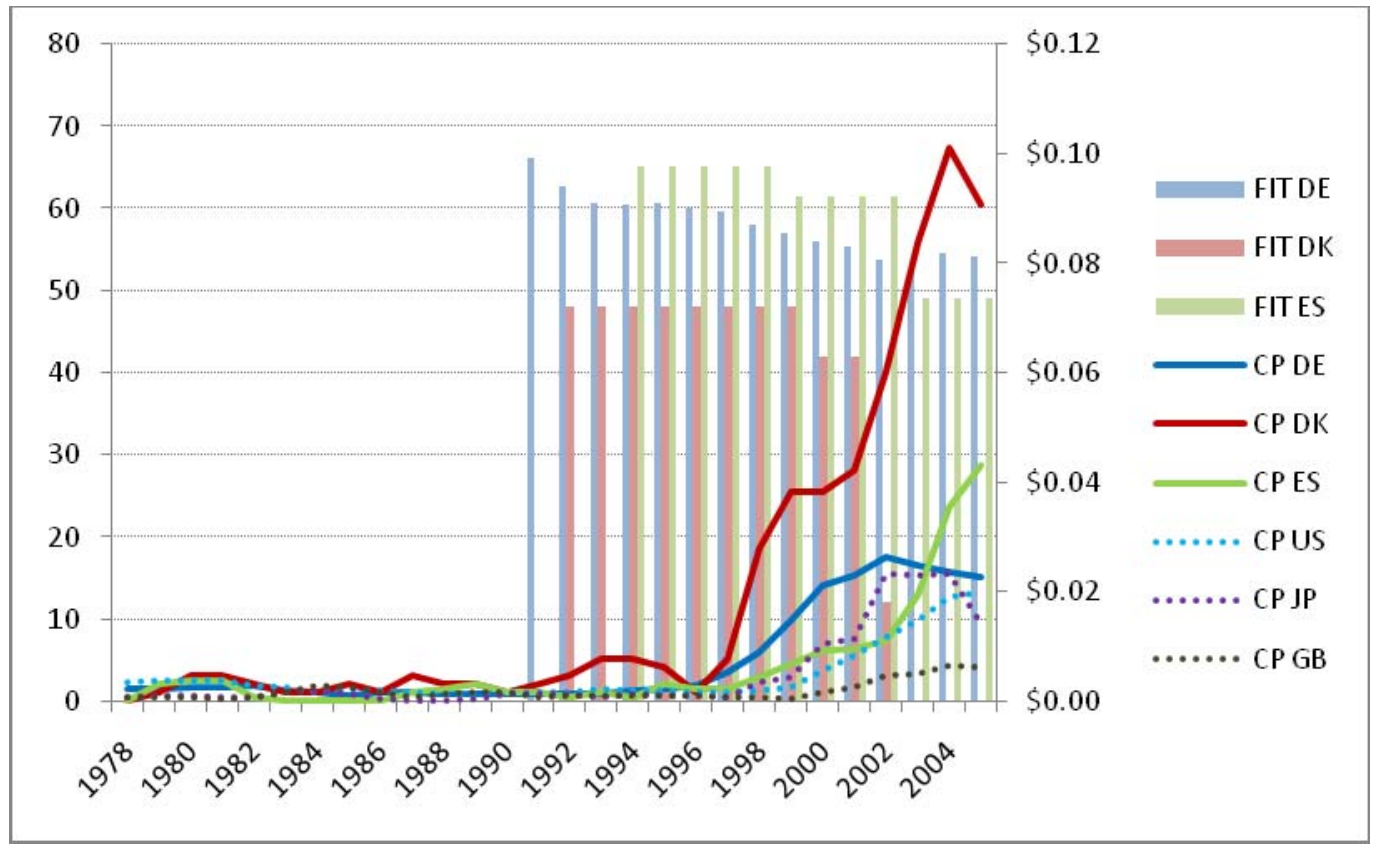




\section{APPENDIX E. USING PATENT DATA AS AN INDICATOR OF INTERNATIONAL TECHNOLOGY TRANSFER}

Patent activity is used in this report as a proxy for technological innovation, that is, the method by which new or enhanced technologies are made available and brought into widespread use. The transfer of technology between countries is investigated by looking at the relationship between the country where the application was first laid and any subsequent duplicate filings in other countries. This Appendix investigates the robustness of using duplicate patent applications to measure patterns and rates of international technology transfer.

Table 17. Technology transfer taxonomy

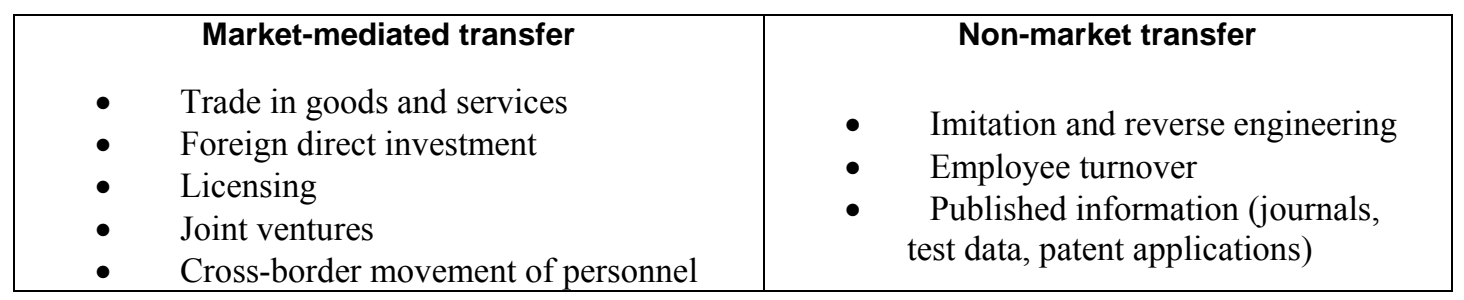

Technology transfer between countries can take many forms; see Table 17 for a market - non-market breakdown (see Maskus 2004 and World Bank 2006). Available empirical evidence strongly supports the finding that the bulk of technology transfer takes place via (i) trade, (ii) foreign direct investment (FDI) and (iii) licensing (Maskus 2004). Precisely which channel is most important depends in part upon the characteristics of the 'recipient country' (i.e. domestic research capacity, strength of intellectual property rights regimes, etc.) and the nature of the technology being transferred (i.e. the potential for imitation and reverse engineering).

The idea of using patent data to measure international technology transfer arises from the fact that there will be a partial 'trace' of the three main transfer channels in patent figures. Moreover, if there is any potential for reverse engineering, exporters, investors and licensors will each have an incentive to protect their intellectual property when it goes overseas. Technology transfer occurring via foreign direct investment and licensing of specific technologies involves the transfer of knowledge, expertise and equipment to another country. This may subsequently diffuse more widely in the economy by other channels - e.g. local employees of the subsidiary taking up employment in domestic firms and carrying knowledge about the technology with them. There is, however, little data to quantify transfer via FDI and licensing in the environmental area.

Trade is a form of transfer where technological innovation embodied in a good improves the capital stock of another country. This transfer can be measured by trade flows. However, in the environmental area, sector or commodity classifications are not sufficiently defined to provide robust EST indicators, whereas patent data can provide such indicators due to their more detailed classification system. It is however, useful to look at the relationship between trade and patent transfer flows in order to substantiate that patent flows between countries are a valid indicator of international innovation transfer. 
For this corroboration exercise, road vehicle data has been chosen as it is an area with large numbers of patents, large measurable trade flows, and comparable definitions. Road vehicle patent and trade data has been used to investigate the robustness of using duplicate patent applications to measure technology transfer.

Patent Flow
Patents have been extracted from the PATSTAT
database for road vehicles with an International
Patent Classification of B62 "Land vehicles for
travelling otherwise than on rail".
There are three ways to measure patent flow
between countries:
1. Inventor country to priority office;
2. Inventor country to duplicate office;
3. Priority office to duplicate office.
Type three, priority office to duplicate office flow
counts are used in the analysis shown below.

Trade Flow
Data has been extracted from the UN COMTRADE
database. Data was extracted for the period 1988 to
2005, using both the HS and SITC classification
systems, SITC = 78 "Road Vehicles" and HS = 87
"Vehicles other than railway or tramway rolling-stock,
and parts and accessories thereof". Both exports
(gross exports less re-exports) and imports (gross
imports less re-imports) were investigated.

Trade and patent transfers between countries are collected for the period from 1988 to 2005. Correlations between patent flows and trade over time and country pairs are shown below. There was trade data and patent transfer counts available for approximately 50 exporting countries and 60 importing countries. Results are presented using all non missing pairs and also with outliers removed, namely flows from Canada to the United States and from Japan to Germany.

Table 18. Correlations between trade values and counts of duplicate patent applications

\begin{tabular}{|l|c|c|}
\hline Correlation between trade flows and duplicate patenting & Full sample & $\begin{array}{c}\text { Sub-sample excl. outliers } \\
\text { (excl. CA-US and JP-DE } \\
\text { flows) }\end{array}$ \\
\hline $\begin{array}{l}\text { Base dataset - all country pairs and all years (1988-2005), } \\
\text { corr(exports, patents) }\end{array}$ & $0.47(4384)$ & $0.69(4348)$ \\
\hline $\begin{array}{l}\text { For each country pair, aggregate over time, } \\
\text { corr(exports, patents) }\end{array}$ & $0.52(825)$ & $0.74(823)$ \\
\hline $\begin{array}{l}\text { For each exporter country, aggregate across partner countries, } \\
\text { corr(exports, outgoing patents) }\end{array}$ & $0.76(446)$ & $0.87(446)$ \\
\hline $\begin{array}{l}\text { For each importer country, aggregate across partner countries, } \\
\text { corr(imports, incoming patents) }\end{array}$ & $0.71(634)$ & $0.76(634)$ \\
\hline
\end{tabular}

Note: Pearson correlation coefficients; Number of observation in parentheses; When trade data was deflated by the US PPI all correlations improved marginally (by 0.01 ).

Patent transfer counts between priority office and duplicate office are extracted from the PATSTAT database $^{20}$ while trade data between countries comes from the UN COMTRADE database ${ }^{21}$. Trade and patent transfers are collected for the period from 1988 to 2005 where there is data available for approximately 50 countries.

To substantiate the use of patent data as a measure of technological transfer, we would expect trade and patent flows to be strongly positively correlated as indeed they are found to be. Firstly, each exportimport pair (1988-2005) is strongly correlated at 0.69. Aggregating over time for each export-import pair gives a correlation of 0.74 . And finally, when aggregating trade and patent data for each exporter

\footnotetext{
${ }^{20}$ IPC code of B62 - Land vehicles for travelling otherwise than on rail.

${ }^{21}$ Using both the HS and SITC classification systems, SITC $=78$ Road Vehicles and HS $=87$ "Vehicles other than railway or tramway rolling-stock, and parts and accessories thereof'
} 
(regardless of who imports) gives a correlation of 0.88 . Figure 40 below plots the last case with aggregate exports on the horizontal axis and total patents transfers from 'exporter' country on the vertical axis. ${ }^{22}$

Figure 40. Aggregate patent transfer counts and aggregate exports for road vehicles 1988-2005.

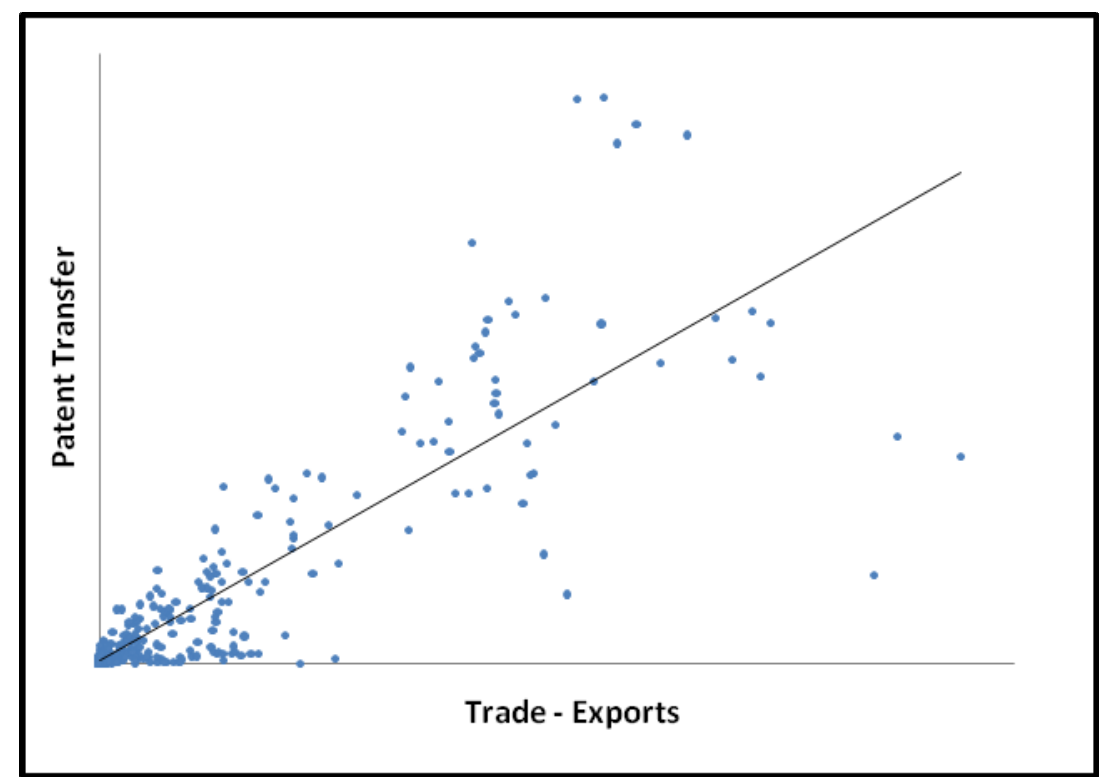

Technological transfer occurs via many channels, though arguably trade, foreign-direct investment and licensing are the most important. Given the lack of suitable data in these areas, in particular with respect to the environmental, patent transfer data which relates to these three channels of international technology transfer, offers a suitable indicator.

\footnotetext{
${ }^{22}$ Results are presented using all non missing pairs and also with outliers removed, namely flows from Canada to the United States and from Japan to Germany.
} 